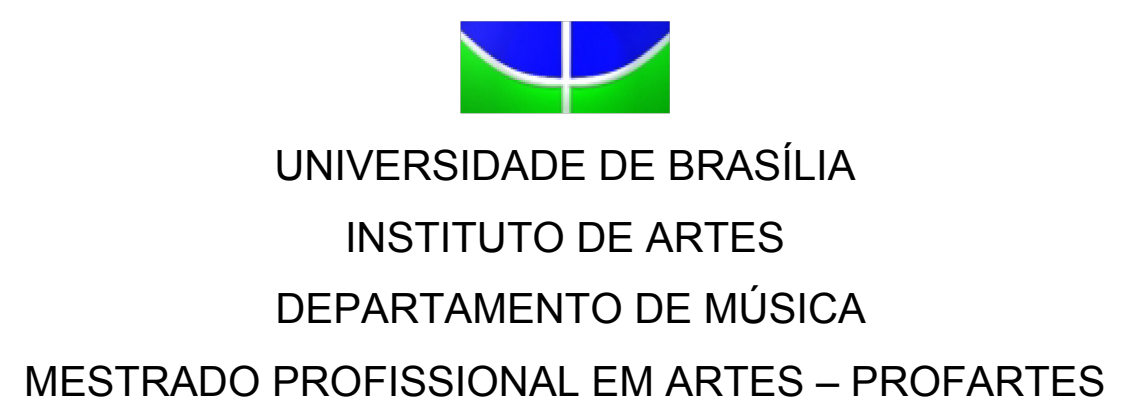

André Felipe de Araujo Arraes

\begin{abstract}
A MÚSICA NA ESCOLA, POSSIBILIDADES E DESAFIOS PARA UMA VIVÊNCIA MUSICAL CRÍTICA E CONSCIENTE: reflexões a partir de aulas de música com alunos do Ensino Fundamental - anos finais
\end{abstract}

BRASÍLIA - DF

2016 
André Felipe de Araujo Arraes

\section{A MÚSICA NA ESCOLA, POSSIBILIDADES E DESAFIOS PARA UMA VIVÊNCIA MUSICAL CRÍTICA E CONSCIENTE: reflexões a partir de aulas de música com alunos do Ensino Fundamental - anos finais}

Dissertação de Mestrado Profissional em Artes - ProfArtes apresentada ao Programa de Pósgraduação do Instituto de Artes da Universidade de Brasília como requisito para obtenção do título de de Mestre em Artes, área de concentração Ensino de Artes - Música.

Orientadora: Profa ${ }^{a}{ }^{a}$ Maria Cristina de Carvalho Cascelli de Azevedo

BRASÍLIA - DF 


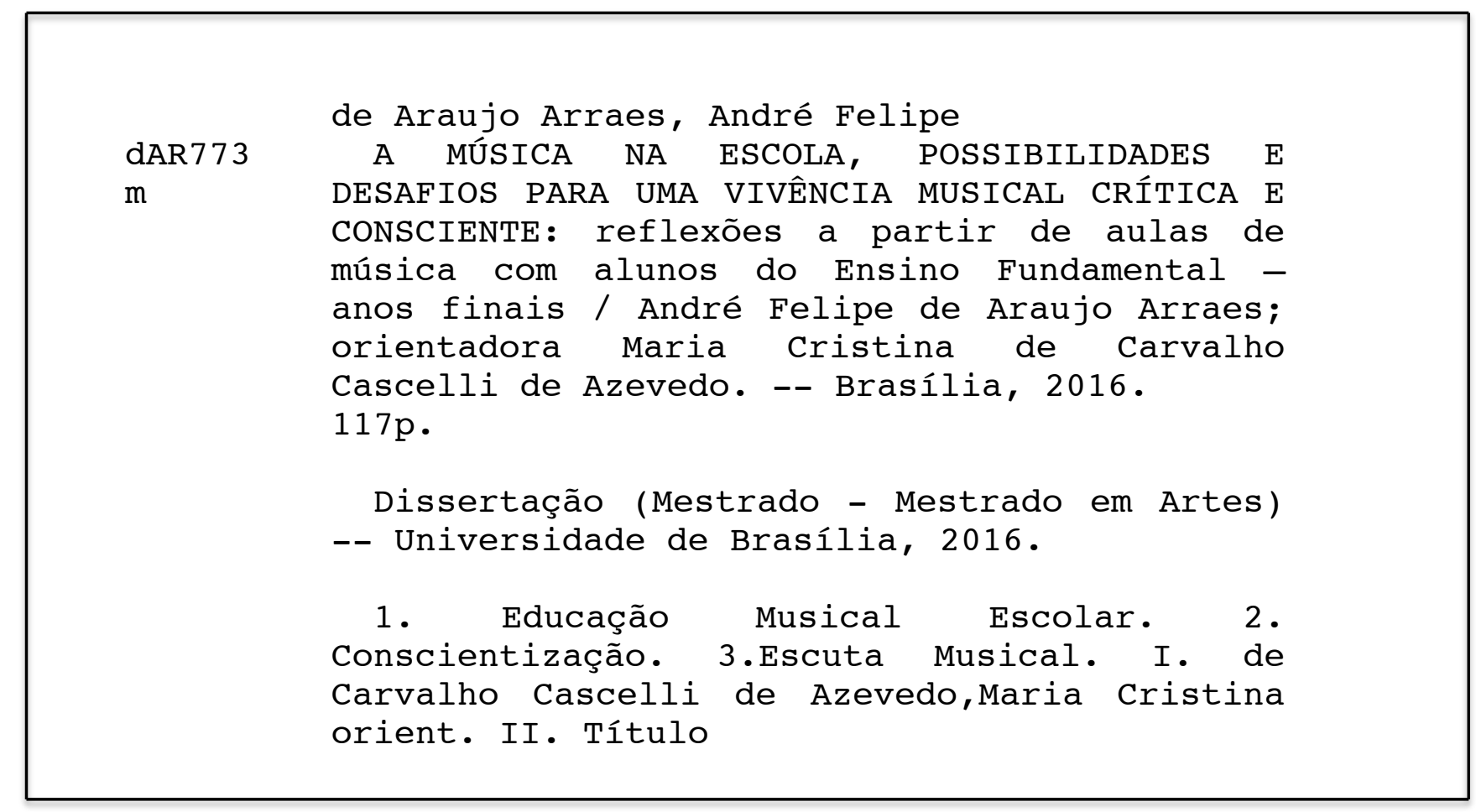




\section{A MÚSICA NA ESCOLA, POSSIBILIDADES E DESAFIOS PARA UMA VIVÊNCIA MUSICAL CRÍTICA E CONSCIENTE: reflexões a partir de aulas de música com alunos do Ensino Fundamental - anos finais}

Dissertação de Mestrado Profissional em Artes - ProfArtes apresentada ao Programa de Pós-graduação do Instituto de Artes da Universidade de Brasília como requisito para obtenção do título de Mestre em Artes, área de concentração Ensino de Artes - Música.

Brasília, ..... de setembro de 2016

Banca examinadora:

Maria Cristina de Carvalho Cascelli de Azevedo

Presidente - Universidade de Brasília

Cristiane Maria Galdino de Almeida

Membro Externo - Universidade Federal de Pernambuco

Flávia Motoyama Narita

Membro Interno - Universidade de Brasília

Delmary Abreu

Suplente - Universidade de Brasília 


\section{RESUMO}

Na sociedade, a música está relacionada a uma grande variedade de funções e significados. Eles têm uma dimensão pessoal e social muito representativa, que pode ser observada nos modos de ser e de pensar de indivíduos e determinados grupos sociais: família, escola, igreja, amigos, mídia. Essa abordagem considera a música como uma prática social, isto é, uma manifestação cultural, artística e humana impregnada pelas realidades sociais. Nessa perspectiva, a presente dissertação tem como objetivo geral refletir sobre as possibilidades e os desafios de aulas de música desenvolvidas para conscientizar os alunos do $8^{\circ}$ ano do Centro de Ensino Fundamental 05 do Paranoá sobre as suas vivências musicais, não as negando, mas expandindo seu referencial de repertório. O estudo situa-se na área da Educação Musical Escolar e se constitui de uma reflexão sobre a prática docente na escola CEF-05 do Paranoá, onde aulas de música foram ministradas por intermédio de um projeto específico. Esse adota a perspectiva da conscientização (FREIRE, 1979), com o intuito de promover a reflexão acerca do fazer musical e das influências da música no cotidiano da sociedade, para promover uma ação cidadã. O projeto se fundamenta nos conceitos de conscientização e empoderamento de Freire (1979) e em literatura da Educação Musical (ABRAHAMS, 2005). A metodologia consiste em uma reflexão sobre a ação (BZERZINSKI; GARRIDO 2008), cujo projeto pedagógico é desenvolvido na turma do $8^{\circ}$ ano A, a partir da vivência de 18 alunos entre 13 e 16 anos. Os resultados revelam que os alunos ampliaram a sua compreensão musical e manifestaram uma dimensão reflexiva sobre a música, bem como, atividade de composição. Os dados demonstram que o cotidiano impregnado de música pode se caracterizar numa valiosa ferramenta reflexiva para os alunos nas aulas de música.

Palavras- chaves: Educação Musical Escolar. Conscientização. Escuta Musical. 


\begin{abstract}
In our society, music is related to a wide range of functions and meanings, which have a very significant personal and social dimension. This can be noticed in the ways individuals and certain social groups - such as-family, school, religion, friends and media - are and think. This approach considers music as a social practice, that is, a cultural, artistic and human manifestation imbued with social realities. In this perspective, this dissertation aims to reflect on the challenges and possibilities of music lessons developed to raise students' awareness of heir musical experiences, not denying, but expanding their repertoire. This is a study in the field of School Music Education carried out as reflective action on teacher's practice with 18 students aged between 13 and 16 years old from the 8th grade, group A, from the Centro de Ensino Fundamental 05, at Paranoá, Brasília, Brazil. This Project adopts Freire's (1979) concepts of conscientization and empowerment, as well as literature from the field of Music Education(ABRAHAMS, 2005). It intends to promote a reflection on musical practices and on the influence of music in the daily routine of the society to promote citizenship. The methodology consists of a reflection on teacher's practice (BZERZINSKI; GARRIDO 2008), developed with-the above mentioned student group. The results reveal that those students expanded their musical understanding and developed their reflection on music and on music making, including-composition experience. The data show that the daily contact with music can be a powerful tool to instigate students' reflection in music classes.
\end{abstract}

Keywords: School Music Education. Concientization. Music Listening. 


\section{SUMÁRIO}

1 INTRODUÇÃO

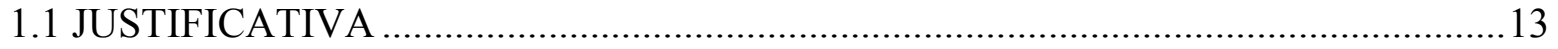

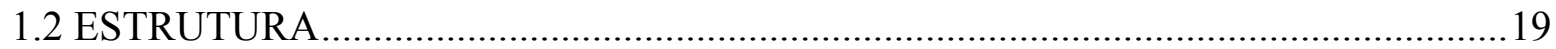

2 A PEDAGOGIA CRÍTICA E ENSINO E APRENDIZAGEM MUSICAL ....................21

2.1 CONCEITOS: CONSCIENTIZAÇÃO E EMPODERAMENTO ..................................21

3 O PERCURSO METODOLÓGICO DAS AULAS DE MÚSICA .......................................35

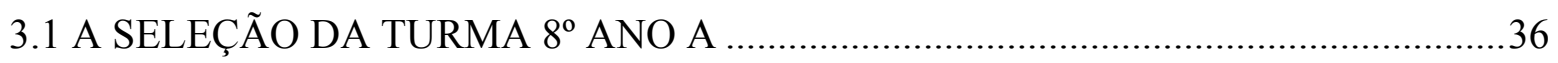

3.2 AS FONTES DE PESQUISA E O PLANEJAMENTO DAS AULAS ............................37

3.2.1 As atividades piloto...................................................................................................37

3.2.2 Os questionários diagnósticos: primeira atividade .................................................39

3.2.3 As Atividades Musicais .................................................................................................43

4 O CONTEXTO PEDAGÓGICO-MUSICAL: A ESCOLA E A COMUNIDADE...........45

4.1. SOBRE CONTEXTO ESCOLA-CIDADE: ALGUMAS REFLEXÕES …………........47

4.2 DO CONTINGENTE DOCENTE E DISCENTE DO CEF 05 DO PARANOÁ.............49

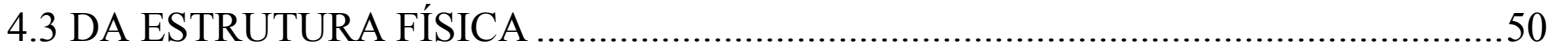

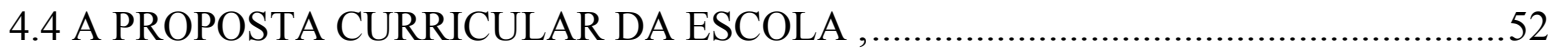

4.4.1 Antecedentes: a Legislação Educacional do GDF: o Currículo em Movimento52

4.4.2 A música na proposta curricular da escola ...............................................................56

5. REFLEXÃO SOBRE OS RESULTADOS .........................................................................58

5.1 OS ALUNOS: QUEM SÃO OS JOVENS DO OITAVO ANO 'A' E SUA RELAÇÃO

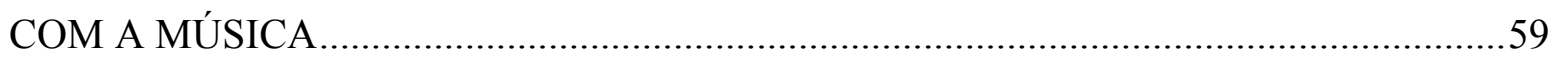

5.1.1 As preferências musicais ...............................................................................................70

5.1.2 Composição Musical........................................................................................................75

5.1.3Apreciação Musical: Musicalidade e conscientização................................................78

6 CONCLUSÃO

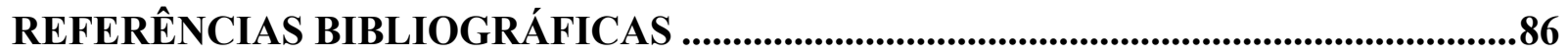

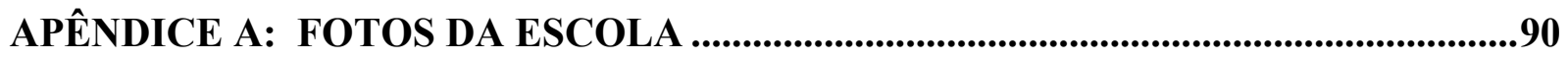


APÊNDICE B: QUESTIONÁRIO DIAGNÓSTICO SÓCIO ECONÔMICO..................95 APÊNDICE C: QUESTIONÁRIO DIAGNÓSTICO PREFERÊNCIAS MUSICAIS ....97 APÊNDICE D: QUESTIONÁRIO DIAGNÓSTICO PRÁTICAS E PREFERÊNCIAS

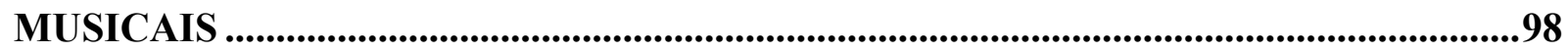

APÊNDICE E: EXEMPLO ANÁLISE DADOS QUESTÕES FECHADAS..................101 APÊNDICE F: EXEMPLO ANÁLISE DADOS QUESTÕES ABERTAS .....................102 APÊNDICE G: PLANOS DE AULA...........................................................................107 


\section{INTRODUÇÃO}

Nesta dissertação, o exercício da docência em música, no Ensino Fundamental (anos finais), em uma escola pública do Distrito Federal (DF), para alunos em defasagem escolar, será o foco de reflexão e partirá de aulas de música baseadas em uma escuta musical ativa, consciente e crítica. Esse é o objeto de análise desta monografia. $\mathrm{O}$ texto entende a música como uma prática social, isto é, uma manifestação cultural, artística e humana impregnada pelas realidades sociais (DYNDAHL; KARLSEN; WRIGHT, 2014). O trabalho situa-se na área da Educação Musical Escolar e se propõe a refletir sobre a aula de música como meio para a conscientização social e cultural.

Aqui utiliza-se o aparato teórico de Freire que aborda a conscientização como uma construção na qual a comunidade toma consciência de seus direitos e deveres. Ao perceber o que acontece ao seu redor, os indivíduos se percebem como sujeitos que interferem no processo histórico e que, como consequência, podem decidir sobre suas ações e escolhas. Essa construção é fruto de uma reflexão crítica sobre seu contexto e ações, o que gera tomadas de decisões mais conscientes e inventivas. Assim, podemos entender a conscientização como desenvolvimento crítico para uma tomada de consciência, que nos capacita e transforma.

Ou como define Freire:

A conscientização está evidentemente ligada à utopia, implica em utopia. Quanto mais conscientizados nos tornamos, mais capacitados estamos para ser anunciadores e denunciadores, graças ao compromisso de transformação que assumimos. Mas esta posição deve ser permanente: a partir do momento em que denunciamos uma estrutura desumanizante sem nos comprometermos com a realidade, a partir do momento em que chegamos à conscientização do projeto, se deixarmos de ser utópicos nos burocratizamos; é o perigo das revoluções quando deixam de ser permanentes. Uma das respostas geniais é a da renovação cultural, esta dialetização que, propriamente falando, não é de ontem, nem de hoje, nem de amanhã, mas uma tarefa permanente de transformação.(FREIRE, 1979, p.16).

Portanto, a conscientização gera uma transformação. Na escola básica, a música pode ser ferramenta de conscientização, de reflexão, de inovação e de construção da cidadania, bem como, de identidade pessoal e coletiva. Por isso, a reflexão proposta nesta dissertação parte do conceito de "conscientização" desenvolvido por Freire (1979) e seguidores que defendem uma perspectiva crítica da educação. $O$ pensamento freiriano nessa abordagem é aporte 
teórico para discutir essa reflexão como ação pedagógica na aula de música. Dessa forma, também, a abordagem da Pedagogia Crítica do Ensino Musical (PCEM) desenvolvida por Abrahams(2005) complementa a fundamentação desta monografia, em que as atividades musicais desenvolvidas nas aulas de música são entendidas como meio para a formação crítica e cidadã.

$\mathrm{Na}$ sociedade, a música não é alienada. Ela está relacionada com uma grande variedade de funções e significados que têm uma dimensão pessoal e social que envolve os modos de ser e de pensar dos indivíduos e de determinados grupos sociais: família, escola, igreja, amigos, mídia. Na escola, esses grupos se encontram e podem tanto dialogar entre si quanto entrar em conflito. A relação dos indivíduos com a música é diversa e as vivências e as experiências que alunos e professores levam para a escola refletem em suas ações e pensamentos. Essa diversidade demanda reflexão.

Ao refletir sobre a música na sala de aula, seu papel e função e as relações dos jovens com a o repertório musical, relembro a minha própria história musical e docente. As minhas experiências têm sido fio condutor para pensar as atividades musicais que escolho e desenvolvo em sala de aula. Na minha experiência pessoal, a cultura artística, o fazer artístico e a docência são uma herança familiar. Nesse contexto fui instruído a ponderar sobre minha opção para a docência em música, atividade considerada cheia de privações e de limitações. Assim, a decisão de me tornar músico só ocorreu mais tarde, aos vinte anos, quando iniciei meus estudos de baixo elétrico. Apesar da atividade musical ser marginalizada profissionalmente, eu percebia, na educação musical, a perspectiva de aliar música e educação e a possibilidade de promover transformações e mudanças efetivas na sociedade como ocorreram na minha própria experiência pessoal.

Na Licenciatura em Música da UnB, tive a oportunidade de aliar essas duas atividades: música e docência. A universidade me propiciou experiência em sala de aula na rede pública com as disciplinas de Práticas de ensino e aprendizagem musical e Estágios supervisionados. Essa experiência me aproximou da realidade do ensino de Artes na rede pública, situação muito mais adversa do que eu pressupunha: a constatação da ausência de aulas de música nas escolas. Ao constatar tal ausência, me deparei com as consequências educacionais desta "lacuna": a falta de compreensão estética, reflexiva e crítica dos alunos. Eles ouviam muita música, mas a compreensão musical não era objeto de estudo e reflexão. 
Quando na condição de estudante do ensino fundamental, não havia me atentado para o fato de que meus colegas não tinham uma cultura musical diversificada ou mesmo para uma falta de intimidade com o conhecimento musical e seu pensamento abstrato. Na formação e atividade docente, comecei a analisar essa questão sob a perspectiva do professor e pude observar e refletir sobre quando, como e porque essa carência educacional dos alunos se manifesta. Nesse sentido, comecei a ponderar, seriamente, sobre a irreversibilidade da situação histórica imposta por cerca de quarenta anos de exclusão do ensino de música nas escolas (de 1971 a 2008), por ocasião da criação da atividade escolar Educação Artística que, gradativamente, "baniu" a música do currículo escolar (OLIVEIRA, 1992). Essa situação tem me inquietado desde minha formação docente e tenho me questionado sobre como reverter os prejuízos dessa exclusão. Nessa direção tenho refletido sobre que tipo de aula de música poderia promover um ensino de música significativo, consciente e que pudesse transformar os indivíduos, seu pensamento e atitudes.

Esse pensamento, ainda amplo, aliado à minha experiência docente como aluno e professor, principalmente, na rede pública do Distrito Federal (DF), me fizeram deparar com a "imensidão" do problema músicoeducacional: o fato de as escolas não propiciarem aos alunos oportunidades e perspectivas para que eles pudessem compreender a realidade musical em que se encontram e promover a sua transformação. A cultura escolar ainda mantém um modelo reprodutor e pouco reflexivo, o que dificulta o desenvolvimento de uma compreensão mais profunda sobre o conhecimento musical, de um modo geral, e sobre o sentido, significado e funções das músicas que os estudantes escutam e que não escutam.

Contudo, como resistência à situação apresentada, a minha experiência docente, especialmente, como professor de instrumento baixo elétrico, me ensinou a perceber o aluno como um sujeito dotado de conhecimentos musicais. Ou seja, o aluno, por mais iniciante que seja, quando escolhe aprender a tocar um instrumento já possui uma compreensão tácita dos elementos musicais e não musicais da música. Essa visão me ajudou a entender que a compreensão musical envolve o conhecimento específico sobre música, o domínio técnico de instrumento musical e a compreensão dos inúmeros papeis da música em seus diferentes contextos sociais. Em outras palavras, saber música vai além do domínio de um instrumento ou de um estilo musical.

Esta premissa se fortaleceu com a experiência docente na Educação Musical Escolar. Primeiramente, em uma escola particular, onde lecionei aulas de música para alunos do ensino 
fundamental do sexto ao nono ano. As turmas eram grandes, cerca de 35 alunos, e a escola estava implementando o ensino de música para se adaptar à legislação que preconiza a obrigatoriedade do conteúdo música na Educação Básica (Lei nº11769 de 2008 e Lei no 13278 de 2016). Esse período foi de muito aprendizado, principalmente, em relação à aula de música, no formato "aulão", que reforçou a ideia de que a música e o fazer musical se relacionam não só com o indivíduo, mas também com sua situação sócioeconômica, sua postura individual e inclusive ideológica.

Na Secretaria de Estado de Educação do Distrito Federal (SEDF), estou trabalhando com alunos do Centro de Ensino Fundamental 5 do Paranoá (CEF-05). Essa experiência tem sido desafiadora. Isto porque o grupo é heterogêneo e inconstante. A população flutuante da escola é fruto de uma constante sazonalidade e há problemas de assiduidade. Há estudos e pesquisas que indicam os fatores que influenciam a percepção e os procedimentos de convivência dos alunos na escola, no sentido do que ela representa para eles. Por vezes, a escola é uma instituição sem significado para o jovem (BRASIL, 2011). A estrutura física e a localização do CEF-05 também são fatores desfavoráveis, uma vez que a estrutura não é adequada para aulas em geral e, mais especificamente, para aulas de música. A falta de estrutura e de suporte, na realidade, são uma constante tanto no CEF-05 do Paranoá quanto em outras escolas em que atuei durante a formação como estagiário ecomo professor da SEDF.

Quanto à relação dos jovens com a música, tenho observado que eles ouvem muita música pelo celular, internet e rádio. Eles possuem, em seu cotidiano, uma prática comportamental muito voltada ao lazer e ao entretenimento como apontam os trabalhos de Vóvio, Dayrell, Mansutti (BRASIL, 2011). Eles parecem gostar mais da produção nacional como o RAP e o Funk carioca, estilos recorrentes. Também ouvem músicas internacionais, mas dão maior audiência para a produção doméstica. A batida dançante é apontada como um dos elementos mais importantes da música. Observa-se, porém, que essas características são referentes às experiências individuais dos alunos. Portanto, não se pode generalizar essa observação para as demais escolas privadas ou públicas, esses dados necessitam de estudos mais aprofundados.

$\mathrm{Na}$ minha experiência docente, em aulas na escola particular, ao questionar os alunos sobre suas preferências musicais pude observar que eles se mostravam muito mais afinados aos fenômenos midiáticos da música internacional do que aos sucessos das redes sociais. Eles 
também se interessam por músicas associadas às trilhas sonoras de games de consoles eletrônicos conhecidos como videogames como os modelos PS3, X box e da TV. Os alunos do Ensino Médio da rede pública, nesse tipo de levantamento, apresentavam, em geral, uma preferência musical associada mais às rádios e à produção popular nacional. Especificamente, no CEF 05, um outro fator soma-se às preferências musicais dos alunos, uma vez que há, na cidade, uma tradição de festas na rua, em que se observa um repertório comum entre a comunidade.

A partir desse relato, ao refletir sobre minha experiência e reflexões como estudante e docente, defendo que a educação e, em particular, a educação musical deve ser uma ferramenta de construção pessoal e reflexiva para conscientização e transformação do indivíduo e da sociedade, atribuindo um maior significado a sua experiência escolar, bem como à comunidade na qual estão inseridos e assim, o aluno pode perceber melhor o seu ambiente. Pela minha vivência familiar, educacional e profissional, entendo que o ensino de Artes, como se define genericamente na SEDF, especificamente o da Música, propicia um "poder transformador", pois pode promover mudanças no pensamento e gerar uma postura reflexiva que se estende para o cotidiano dos alunos, transformando sua compreensão sobre sua realidade musical e sociocultural.

Nesse processo, a educação é conscientizadora e não mercantilista. Segundo Ball (2010), uma visão unilateral e mercantilista das relações sociais e da educação ocasiona um problema educacional, uma vez que a educação assume o caráter de suprir as demadas do mercado financeiro. Entre outros, tal aspecto pode ser contraposto por uma abordagem do ensino da música em que o indivíduo possa refletir sobre esse paradigma. Em um processo de conscientização, de desvelamento, o indivíduo passa a perceber as intenções mercantilistas sob outra perspectiva e passa a relativizá-las, pois se percebe como agente histórico, crítico e ativo na realidade que o circunda. De acordo com a abordagem de Freire (1979), essa perspectiva educativa pode tornar o indivíduo consciente das "ideologias" limitadoras do pensamento que permeiam as sociedades. Essas tendem a aprisionar o indivíduo numa postura que consiste em não aprofundar as reflexões sobre o fazer e a vivência musical, o que pode por vezes, incorrer em uma ideologia que consiste em esvaziar a autonomiados indivíduos e impossibilitar a conscientização.

Ao me deparar com a situação do ensino musical na Educação Básica e ao considerar a educação musical como ferramenta para a conscientização questiono até que ponto a aula de 
música pode propiciar a conscientização dos alunos sobre suas vivências musicais, não as negando, mas expandindo seu referencial de repertório. Quem são esses alunos e quais são suas preferências e práticas musicais? Que tipo de atividades musicais podem ser desenvolvidas para estimular o aluno a pensar sobre suas vivências musicais? Que mudanças de atitude podem ser observadas nesses alunos?

Considerando a problematização e os argumentos apresentados anteriormente, esta pesquisa pretende, como objetivo geral, refletir sobre as possibilidades e os desafios de aulas de música desenvolvidas para conscientizar os alunos do $8^{\circ}$ ano do CEF 05 do Paranoá sobre as suas vivências musicais, não as negando, mas expandindo seu referencial de repertório.

Especificamente esta dissertação intenta:

1) Identificar o perfil sócioeconômico e musical dos alunos do $8^{\mathrm{a}}$ ano $\mathrm{A}$ do CEF 05 do Paranoá;

2) Descrever e analisar as atividades musicais desenvolvidas em sala de aula;

3) Refletir sobre as 'mudanças' de atitude observadas nos alunos.

Esta monografia se justifica pelos motivos apresentados a seguir.

\subsection{JUSTIFICATIVA}

Neste estudo, o aluno se apresenta como agente musical ativo e capaz de exercício reflexivo sobre o próprio fazer musical, para além da música entendida como objeto de entretenimento. Assim, nessa mesma linha, é importante observar a relação da identidade do sujeito com os modelos e valores defendidos pela cultura musical. Desse modo, é possível perceber de que maneira a ressignificação das referências musicais por intermédio de uma abordagem educacional conscientizadora pode contribuir para transformar o pensamento e a autoestima desse jovem.

Não raro, nas minhas aulas, me deparo com a dificuldade dos indivíduos em estabelecer ligações entre o passado e o presente, no sentido de entender o processo cultural como algo dinâmico, em construção, o que depende de uma noção de continuidade, de uma reflexão sobre o processo. Ou seja, o aluno não entende muitas vezes a cultura como um processo civilizatório, porque muitas vezes não consegue conceituar nem mesmo o que é cultura ou pensar sobre seu papel na sua cultura (SANTOS, 2009). 
Entretanto, há situações em que o aluno consegue estabelecer uma ponte entre o que vive e estuda, entre o aprender e o seu cotidiano. Estas devem ser constantes. Segundo Freire (1979), o aluno aprende aquilo que é significativo para ele. Contudo, se ele é "alienado" ou "manipulado" o que é importante ou significativo? Nesse sentido, pensar e elaborar ações que despertem no aluno um questionamento mais direcionado ao que ele escuta, às suas vivências e conhecimentos, deve ser pensado constantemente, no intuito de aproximar as linguagens formais e informais na estruturação do pensamento crítico. Essa aproximação é relevante, pois amplia o repertório conceitual e teórico do aluno a partir de suas vivências musicais.

Por vezes, é importante assegurar que o aluno consiga explicar, para si a para os outros, que o ritmo que ele ouve possui "frases bonitas"; tem uma boa "variação de ideias"; possui um "pulso intenso"; utiliza uma melodia com "saltos" e com "variações de notas"; possui um "refrão empolgante". Assim, promover a aprendizagem de um vocabulário específico musical é empoderar o aluno de uma linguagem formal que o aproxima de uma compreensão musical capaz de transformar sua vivência musical e orientar suas escolhas e justificativas. Essa compreensão contribui para uma outra intelecção e estabelece novas possibilidades de sons, sentimentos, ideias e significados para esse indivíduo e o mundo com o qual ele interage e transforma.

Um dos efeitos subsequentes desse tipo de ação, faz com que ao promovê-las, indiretamente, também, acaba-se por fomentar a justiça social. A noção de justiça social,é entendida em seu aspecto humano e comunitário. Segundo Barzotto (2004):

O sujeito na justiça social, isto é, aquele a quem é devido algo, é, portanto, a pessoa humana. São-lhe devidos todos os bens necessários para a sua realização nas dimensões, individual, racional e social. $\mathrm{Na}$ justiça comutativa, abstrai-se a comunidade (em um primeiro momento: todajustiça particular está vinculada, em última instância, ao bem comum, como foi visto); na justiça distributiva, considera-se o indivíduo no locus específico que ocupa no interior da comunidade. Na justiça social, ele é considerado simplesmente como uma pessoa humana membro da comunidade. (BARZOTTO, 2004, p.43).

Outro aspecto a considerar numa abordagem educacional crítica e conscientizadora é a aproximação entre o conhecimento informal e o formal segundo Freire e Shor(1986) ou entre os conhecimentos prévios do aluno e o conhecimento disciplinar e prático. No livro de Freire e Shor(1986), os autores se referem às linguagens formais e informais na língua portuguesa, 
porém esse mesmo raciocínio pode ser empregado no que se refere à linguagem musical. $\mathrm{O}$ que pode ser identificado como a formalização de conhecimentos e práticas é um dado importante no processo de construção social e cultural. Este dado é consequência de um processo de transmissão e construção de conceitos ao longo das gerações. Compreender esse processo possibilita desenvolver uma concepção pedagógica e propor atividades didáticas em constante avaliação e reelaboração que poderão promover uma educação crítica (ABRAHAMS, 2005).

Pode-se verificar pelo cotidiano da sala de aula, que o contexto da pós-modernidade, associado ao processo de globalização e midiático, parece interferir nas relações e interações. Não obstante, no processo de mercantilização da educação (SANTOS, 2002), a formulação dos currículos apresenta essa tendência. Nesse sentido, a educação musical deve se preocupar e orientar o aluno a refletir sobre esse fenômeno social e sobre a quem ele interessa.

Nessa situação, a análise da dimensão mercadológica da Arte, especialmente da Música, é relevante e deve ser considerada, porém não é a única fonte de conhecimento na formação do jovem. A Música pode e deve, também, transmitir e ser considerada pela sua estética e função social, por isso deve ser admirada e exercida sob a perspectiva de outros valores, para além da promoção do bem-estar, e em direção do intelecto e da capacidade reflexiva para o incremento de uma formação cidadã do indivíduo.

Sob essa perspectiva, o professor deve, junto com seus alunos, abordar e refletir sobre a música como prática social à luz da perspectiva da educação musical. Em termos gerais, a educação musical, não prescinde da necessidade de abordar certos desafios que a própria educação como um todo enfrenta. Tal linha argumentativa, encontra ressonância nas palavras de Ball (2010):

A educação está cada vez mais sujeita aos processos de mercantilização e privatização que são algumas das principais características da política de educação global no século XXI e uma tendência crescente, sob diferentes formas, em países com históricos culturais/políticos e posições econômicas bastante diversas. (BALL, 2010, p. 15).

Vemos que pelo já crescente cortes de orçamento para o ensino das artes, e uma orientação em alguns grupos políticos brasileiros que aponta uma forte tendência para que a música fique em segundo plano. Ou ainda contribui-se nos discursos de funcionalidade ao 
mercado financeiro a idéia de que a arte é e algo secundário ou estritamente associado ao entretenimento ou ao mercado cultural.

Apesar de o Distrito Federal possuir espaços educacionais que formaram gerações de músicos como as Escolas Parque e o Centro de Ensino Profissionalizante Escola de Música de Brasília (CEP-EMB), quanto à educação musical formal, pode-se dizer que ainda há carências e lacunas a serem resolvidas e preenchidas. A oferta de formação musical sistematizada e gratuita é, predominantemente, encontrada no Plano Piloto, área nobre e central de Brasília. Apesar das recém escolas parques inauguradas em Brazlândia e Ceilândia, a periferia do Plano Piloto tem pouco acesso à formação musical escolar.

A demanda por oferta de educação musical nas escolas públicas deve ser observada atentamente, pois essa carência é consequência tanto das políticas educacionais do estado quanto do comportamento da população, no tocante à conscientização do papel do fazer musical na formação do indivíduo. Essa política tem privado a população de ferramentas reflexivas fundamentadas no fazer artístico como um todo e, mais especificamente, na música. Quanto mais elaborado e reflexivo é o pensamento de um indivíduo, menor parece ser a probabilidade dele ser manipulado, ou como queira, comprar ou reproduzir algo de forma intempestiva. Conscientizar o aluno do paradigma reprodutor e passivo que, involuntariamente, ele pode, por ventura, vir a perpetuar, aponta para um exercício reflexivo que pode fornecer ao indivíduo uma possibilidade de transformação e incremento de sua reflexão. Processo que o influenciará e a seus pares.

Contudo, não se quer aqui transmitir a falsa impressão de que esta pesquisa parte da premissa de que os alunos não tenham nenhuma capacidade reflexiva ou consciência cidadã. Pelo contrário, entendo que é significativo partir da vivência do aluno e de suas concepções para, por meio de aulas de música direcionadas e baseadas na observação cuidadosa, atenta e participativa, identificar as potencialidades e eventuais deficiências a fim de promover o crescimento intelectivo e reflexivo desse aluno. Parte-se, portanto, da percepção de quem é esse aluno, como ele se vê, bem como, de que maneira ele compreende a sociedade na qual interage e está inserido, para juntos, de forma dialógica, promover a conscientização e a liberdade de escolha, de mudança.

Essa abordagem pedagógica ganha específica relevância quando se refere ao público adolescente que, de modo geral, é visado pelo mercado, absorve suas tendências e consome de maneira, por vezes, pouco ou insuficientemente crítica o que se impõe. Por isso a importância 
de reconhecer o jovem como um sujeito social, dotado de opinião, conhecimentos e de uma visão particular de mundo (DAYRELL, 2003).

A música como entretenimento pode ser analisada sob essa perspectiva mercadológica e publicitária. Por vezes essa associação se torna tão contumaz e estreita que é quase como se a Música tivesse, exclusivamente, a função de proporcionar uma sensação de saciedade: "o prazer é a marca estética do novo senso comum" (SANTOS, 2009, p.114). Santos continua:

O conhecimento-emancipação privilegia o próximo como forma de conceber, compreender o real, que o real seja o global ou o futuro. Só a ligação proximidade, mesmo a uma proximidade nova e desconhecida, pode conduzir ao reencantamento do mundo (SANTOS, 2009, p.115).

Nesse sentido, a aula de música ao aproximar o aluno de atividades de composição cria possibilidades para ele se manifestar, se expressar musicalmente e se tornar um melhor ouvinte e músico. O fazer musical pode fornecer ao aluno o encantamento que o auxilie em sua emancipação.

Considerando a música como manifestação de um trabalho de concepção intelectual, que estabelece uma linguagem formal, construída ao longo dos séculos e transmissora de ideias, habilidades e conceitos, fomentar a cultura do que se deve ouvir, determinada pelo mercado, apesar de relevante, não é suficiente para que se forneça uma educação satisfatória. Nesse sentido, o conhecimento-emancipação no contexto musical pode ser entendido como a oportunidade de contato com novas manifestações musicais, desconhecidas e estranhas, que possam ser aproximadas para ampliar a visão de mundo do indivíduo. Por outro lado, tampouco é suficiente, prescindir das relações e valores humanos que permeiam o fazer musical.

Nesse sentido, o professor ao aproximar as linguagens formais e informais (FREIRE; SHOR, 1986) permite que o aluno vivencie o processo de conscientização por intermédio de uma pedagogia crítica (GIROUX, 2001), em que as interações sociais permeadas pelo fazer musical são levandas em consideração (DYNDAHL; KARLSEN; WRIGHT, 2014). Este parece ser um exercício pertinente para que o aluno se compreenda como "sujeito social" e que seja capaz de fazer suas escolhas de maneira reflexiva. Uma estratégia satisfatória, como enunciado anteriormente, é partir do universo de vivências, experiências e preferências do 
aluno e discutir sua escuta cotidiana para que essa possa se tornar uma audição mais consciente e aberta à apreociação de conhecimentos formais acerca da própria música.

$\mathrm{O}$ ambiente escolar tem papel fundamental nesse processo e não deve compactuar com a ideia subjacente, muitas vezes frequente entre os estudantes: a música como produto de entretenimento ou, ainda, associada ao mercado de consumo, esse determinante do estilo, do comportamento e do padrão de consumo. A escola, como espaço de socialização e de criação e aprimoramento das relações humanas, deve fornecer aos alunos ferramentas reflexivas acerca do seu cotidiano dentro e fora dela. Neste sentido, as soluções para uma pedagogia crítica no ensino da música encontram ressonância para o aprimoramento dos alunos como músicos. (ABRAHAMS, 2005).

Não há dúvidas que os avanços tecnológicos e os artefatos culturais transformaram positivamente a sociedade e têm influenciado a forma como as pessoas consomem música. Portanto, ignorar aspectos musicais e não musicais na escuta, no consumo e difusão da música interfere no processo de compreensão musical. O desenvolvimento da mídia de massa, os avanços tecnológicos e os artefatos culturais, desde a invenção do gramofone, à popularização do rádio e à disseminação da internet, demonstram as transformações da relação entre o homem e a música. Não é raro, no cotidiano urbano, testemunhar cenas em que a música está sendo consumida individualmente, como pano de fundo ou como composição de uma paisagem sonora. Como exemplo, destaco: a escuta individualizada dos adolescentes nas paradas de ônibus, no meio-fio nas calçadas, nos espaços escolares, inclusivenas salas de aula; a trilha sonora disseminada pelos sons de carros,de rádios, de aparelhos de som, de bares ou espalhados por megafones em carros de som. A paisagem sonora urbana é ruidosa, porém altamente impregnada de música. Esses artefatos tornam a compreensão do fenômeno cultural tão amplo e diverso, mas, ao mesmo tempo, fundamental para a compreensão de mundo.

A educação musical possui, portanto, um amplo campo de atuação e privilegia-se do fato de ser um exercício que encoraja e promove soluções criativas, o que faz com se possa elaborar alternativas profícuas e relevantes para a formação crítica e cidadã.

Dito isto, nesta monografia, busco não negar as referências cotidianas do uso da música, mas, abordá-las sob uma perspectiva reflexiva mais abrangente, envolvendo a transformação da compreensão musical dos alunos. Para a contemplação dos objetivos desta presente pesquisa, considero fundamental, nas aulas de música, construir uma compreensão prática, teórica e contextualizada do fazer musical. Tais procedimentos, também devem ter em 
conta o contexto escolar e a comunidade com a qual a escola se insere e dialoga. A partir da compreensão dessas relações, a aula de música estará mais alinhada com uma educação musical efetiva e autônoma. Assim, poderá empoderar o aluno de ferramentas que possam muni-lo de um espectro mais diverso de expressão e compreensão sensível do ambiente que o circunda, seja este um contexto proeminentemente musical ou não.

Contudo, os elementos a serem observados são inúmeros, o que faz que se tenha, também, a consciência de que não é possível observar todos os elementos implicados. Ainda assim,deve haver o esforço de se trabalhar de maneira abrangente dentro da ideia de que é necessária a compreensão de fatores sociais explícitos e implícitos no jogo social de inclusão e exclusão musical. Nesse sentido, o professor deve ter consciência de sua responsabilidade ética, pois como afirma Bowman (2007, p. 113, tradução do autor) ${ }^{1}$ : "Como um fenômeno fundamentalmente social e um meio poderoso de mediação de inclusão e exclusão, a música está sempre profundamente comprometida com dimensões éticas e suas implicações[...]”.

Nessa concepção, compreender o papel da música na juventude, como algo que os ajudará a formular conceitos, parece uma conclusão razoável. A forma como o jovem se relaciona, se identifica e interage com a música e seu contexto sóciocultural é fundamental para compreender o significado que ele atribui a ela. Por outro lado, é fundamental também compreender o local em que situa esse jovem em suas diferentes dimensões como: as dimensões geográficas, históricas culturais e políticas. $\mathrm{Na}$ busca da compreensão desses elementos, o professor deve procurar situá-los em uma abordagem pedagógica eficiente, real e integradora em que a escola e a sala de aula assumam seu papel formador.

\subsection{ESTRUTURA}

A presente dissertação, em seu primeiro capítulo, se constitui desta Introdução em que o interesse na pesquisa e a problematização são apresentados, seguidos pelos objetivos de pesquisa e pela justificativa que consiste no embasamento argumentativo para o desenvolvimento da pesquisa.

\footnotetext{
${ }^{1}$ As a fundamentally social phenomenon and a powerful means of mediating inclusion and exclusion, music is always an undertaking with profoundly ethical dimensions and implications." (BOWMAN; 2007).
} 
O segundo capítulo apresenta o aporte teórico, no qual são descritosos pressupostos que embasam e permeiam a discussão desta pesquisa. Prossegue-se com uma apresentação de literatura na área, esta organizada a partir de levantamento bibliográfico efetivado com descritores relacionados à pesquisa. $\mathrm{O}$ capítulo finaliza com um exercício sobre a relação entre a pedagogia crítica e a educação musical na tentativa de apresentar possibilidades pedagógicas para uma educação musical crítica.

A metodologia é apresentada no terceiro capítulo, em que se aborda o campo empírico, as fontes e o planejamento da pesquisa, bem como, a aplicação dos questionários, a coleta de dados, as ações em sala de aula e a apresentação dos dados.

O quarto capítulo apresenta o contexto pedagógico-musical do CEF-05 do Paranoá e detalha as características gerais do contigente docente e discente. Mais adiante, a estrutura física da escola é descrita com a finalidade, também, de se relacionar o contexto físico às limitações e às potencialidades pedagógicas do espaço. A relação do contexto escola-cidade expõe, brevemente, as relações da escola, seu surgimento e contexto. Prossegue-se com a discussão curricular da escola, do Projeto Político Pedagógico (PPP), suas potencialidades e fragilidades relacionadas ao ensino de Artes/Música.

A reflexão sobre os resultados é desenvolvida no quinto capítulo, em que apresento os alunos do oitavo ano A do Centro de Ensino Fundamental (CEF) 05 do Paranoá e suas preferências musicais; as atividades musicais desenvolvidas e as reflexões que os resultados sucitaram.

O trabalho finaliza com as considerações finais, em que são retomados os objetivos, as etapas da pesquisa e as reflexões geradas neste processo investigativo e reflexivo. 


\section{A PEDAGOGIA CRÍTICA E ENSINO E APRENDIZAGEM MUSICAL}

Neste capítulo busca-se apresentar conceitos considerados relevantes para uma abordagem crítica com foco no conceito de conscientização. Esse entende que a reflexão transforma e faz com que os indivíduos, ao se reconstruírem, passem a ter uma consciência ativa e transformadora do meio por intermédio do autoquestionamento e do questionamento do meio, ou seja, consciência e ação. Esse processo faz com que o indivíduo, ao participar desse exercício dialético, se torne sujeito de sua aprendizagem e se empodere. Assim, a Arte e, mais especificamente, a Música é utilizada como ferramenta para que o aluno e o professor dialoguem e desenvolvam o ensino e aprendizagem musical crítico na sala de aula.

\subsection{CONCEITOS: CONSCIENTIZAÇÃO E EMPODERAMENTO}

Situar a pedagogia crítica em um contexto musicoeducacional, em que as ações pedagógicas promovam o pensamento crítico, é um dos desdobramentos teóricos que advém da teoria crítica (SPRUCE, 2012). Assim, o estudante, ao conectar aquilo que aprende em sala de aula com a sua realidade social, restrita e mais ampla, vivencia um exercício de prática reflexiva contextualizada o seu cotidiano e a sua realidade social e política. Ele começa a estabelecer associações entre o fazer musical o seu contexto. Passa a entender o que aprende na aula de música como algo que dialoga e questiona seu cotidiano.

A pedagogia crítica no contexto pedagógico-musical é definida como um exercício no qual o professor e o aluno estão sempre dialogando com a dimensão política e social do meio em que estão inseridos. Esses diálogos constroem o pensamento crítico e a conscientização do aluno, que passa entender a música como um exercício de transformação social. $\mathrm{O}$ aluno e o professor estão sempre em construção e reconceitualizando a própria realidade social e as possibilidades que o ensino da música suscita. (ABRAHAMS, 2005).

Ao propor uma pedagogia crítica para o ensino de música, alguns conceitos e princípios são incorporados à aula de música, como o conceito de conscientização e de empoderamento. Delimitar cada um desses conceito é necessário quando se pretende trabalhar com os princípios que fundamentam o pensamento crítico. Spruce (2012), quando propõe uma reflexão sobre o pensamento crítico (critical thinking) convida o leitor a compreender como a teoria crítica define esses princípios sempre partindo da realidade social dos alunos. Para ele, 
o pensamento crítico, bem como, a compreensão crítica são uma das bases da teoria crítica e, quando incorporados com propriedade a educação, capacitam os estudantes "a fazer conexões entre sua aprendizagem musical na escola e sua realidade vivida, e assim, os empoderam como aprendizes" 2 (SPRUCE, 2012, p.185, tradução do autor). Spruce (2012) critica o desenvolvimento do pensamento crítico de forma isolada e reduzida a uma habilidade cognitiva. Segundo o autor, o pensar criticamente está relacionado ao contexto social, moral, social ou político. O seu conceito de pensamento crítico é definido como o "elemento chave no desenvolvimento de uma sociedade socialmente mais justa em que todos são completamente capazes de participar." 3(SPRUCE, 2012, p.185, tradução do autor).

A partir de Spruce (2012), é possível afirmar que a conscientização e o empoderamento são consequência da formação e do desenvolvimento de um pensamento crítico. Segundo Freire e Shor (1986), o empoderamento se dá quando o aluno se liberta das fronteiras entre as linguagens informal e formal. Assim, o aluno passa a perceber a complementaridade entre a formalização de certos conceitos acadêmicos que são associados a certos contextos sociais e a informalidade das linguagens formais e informais que permeiam o cotidiano. Por exemplo, o aluno ao compreender a notação musical, os parâmetros do som, uma análise musical sobre a temática da canção ou realizar uma simples composição brincando de batucar com seus colegas está de forma autônoma e empoderada trabalhando direta ou indiretamente conceitos formais e informais, bem como, incorporando ao seu contexto fatores não diretamente musicais que auxiliam na sua interação social e na sua formação como sujeito e indivíduo criativo.

Quando o estudante percebe que sua experiência intuitiva e a sua aprendizagem formal se complementam, esse aluno é liberto da perspectiva parcial do domínio de uma visão da prática e da execução e da percepção musical.

O diálogo associado ao pensamento crítico, à pedagogia crítica e à educação libertadora ${ }^{4}$ e os conceitos oriundos de suas intersecções são relevantes para entender as múltiplas influências antropológicas, sociais e históricas que parecem estar,

\footnotetext{
${ }^{2}[\ldots]$ properly embedded, critical thinking an understanding enables pupils to make connections between their musical learning in school and their lived reality, and thus empower them as learners.

${ }^{3}$ [...] a key elemento in the development of a more socially just society in which all are enabled to fully participate.

${ }^{4}$ [...] aqui entendo "educação libertadora" como exercício dialógico e crítico a respeito do que é feito, do que se faz, como, quando e onde se faz música, não obstante, sempre questionando quem faz música.
} 
imprescindivelmente, os correlacionando. Indo mais além, interrelações conceituais parecem dialogar ainda com questões epistemológicas, de âmbito filosófico, que refletem no escolar.

Desenvolver o pensamento crítico e a conscientização, tanto do professor quanto dos alunos, é importante para a constituição de uma amálgama de referência para a realização de práticas em sala de aula. $\mathrm{O}$ aluno e o professor questionam e relacionam aquilo que aprendem a suas realidades e as transformam pela prática do exercício reflexivo e se empoderam dessa prática para sua vida

A forma como o educador entende seu contexto de trabalho e a sociedade interferem na sua ação pedagógica. Por isso, a importância de uma formação críticorreflexiva do professor (AZEVEDO, 2007).

No contexto educacional atual, no que diz respeito às periferias de grandes centros urbanos, mais especificamente no Distrito Federal, na Região Administrativa do Paranoá, pode-se observar as influências da globalização como um dos elementos das práticas educativas, quando em diálogo com elementos da pós-modernidade, como o fluxo de informações e acesso a múltiplas referências culturais, estabelece uma série de referências, ajuda estabelecer uma série de tendências e orientações ideológicas e comportamentais, que parece por vezes, atender a necessidade do fluxo mercantil (SANTOS, 2002). Assim, o indivíduo precisa mediar e digerir uma variedade de elementos cotidianos, que podem sobrecarregar o trabalho do professor, o repertório de conhecimentos do aluno e toda a sociedade de consumo, devido a inúmeros elementos objetivos e subjetivos levados para a sala de aula como: as tecnologias móveis; as mídias sociais; as particularidades dos indivíduos; a cultura familiar e escolar.

Somam-se a essa diversidade de elementos, as referências e preferências dos estudantes, as condições adversas de logística da escola, a escassez de material, a estrutura física e pessoal insuficiente, em que se destacam espaços inadequados, más condições de trabalho, demanda burocrática por resultados e números, limitação temporal da aprendizagem, condição sócio econômica, grau de escolarização da comunidade, entre inúmeros fatores que são vivenciados no cotidiano da sala de aula. Esses fatores são intervenientes e afetam o ensino e aprendizagem e a aula de música.

Mais especificamente, em um contexto educacional tão adverso, é muito importante que o professor conheça a comunidade em que está inserido e obtenha dados sobre o desenvolvimento sócioeconômico da região e sobre a cultura musical dos alunos 
(ABRAHAMS, 2005). O professor, na condição de pesquisador, deve estar consciente do seu papel político, não tão somente da pedagogia ou da educação musical, mas também do entendimento de que a pesquisa é uma tomada de posição política e da condição social e cidadã do próprio pesquisador. Tal perspectiva, encontra ressonância no seguinte texto de Demo (2006, p.14): “como ator social, o pesquisador é fenômeno político, que na pesquisa, o traduz sobretudo pelos interesses que mobilizam os confrontos e pelos interesses aos quais serve". Assim, o pesquisador deve ter uma postura crítica acerca de sua prática e aquilo que pesquisa, bem como a consciência do contexto social desse exercício.

Essa demanda ocasiona uma pressão no profissional de educação. Ainda, o professor deve estar atento às questões de consumismo exacerbado e de substituição de valores divulgados pela mercantilização das relações. Essa mercantilização das relações encontra grande ressonância com as mensagens propagadas, em sua maioria, pela música da moda. Assim, o pesquisador deve evitar a postura de salvador e estar atento a generalizações e préconceitos que ele mesmo carrega, fornecer aos alunos que o exercício musical não está tão somente relacionado às relações de consumo como sugere o repertório cotidiano das mídias de massa, não deve ser visto como uma coisa que irá salvar o indivíduo de sua ignorância. Ainda na visão de Moraes, o jovem, imerso em um contexto consumista, possui cada vez mais, uma capacidade de absorção das diversas influências, o que pode, entre outros, contribuir para gerar uma estado "multifrênico" (MORAES, 2006). O estado multifrênico é a condição de sobrecarga de exigências, estímulos e demandas do cotidiano sobre o indivíduo.

Assim, tem aparecido como uma tendência para o esvaziamento do discurso crítico e politizado, a imposição de um volume de informações inseridos no contexto social do indivíduo. As constatações advindas de Moraes (2006) parecem indicar que está designado ao cidadão a absorção das diretrizes conceituais e comportamentais ditadas pelo cotidiano de uma sociedade de consumo, saturando a capacidade reflexiva do aluno com proposições e uma ideologia de não reflexão, em que a rapidez e a superficialidade são valores indiretamente sugeridos como virtudes intelectuais.

Nesse sentido, o jovem precisa, por intermédio de sua escolarização, discutir e tornarse cônscio das dinâmicas que preconizam um comportamento alienado por intermédio de um currículo neoliberal (BALL, 2010). O currículo neoliberal dialoga com a ideologia de funcionalidade para o mercado daquilo que se ensina na escola. 
Observa-se então que para se promover uma reflexão nas aulas de música sem prescindir de uma abordagem que promova a conscientização, primeiramente, precisa-se desconstruir a ideia de que exista a educação como produto, ou seja, a ideia de que a educação tenha a função de formar consumidores de ideologias posturas e padrões de consumo e produção.

Para isso, no processo de conscientização do aluno, o conceito de "empoderamento" do indivíduo é essencial para que ele possa aproximar as linguagens informais e formais (FREIRE; SHOR, 1986) em uma abordagem pedagógica em que se leve em consideração a importância de trazer a fala do indivíduo, a sua conscientização (FREIRE, 1979).

Seria, portanto, necessário, ao que parece, uma sociologia da integração como proposto por Dyndahl, Karlsen e Wright (2014). A sociologia da integração consiste numa perspectiva educacional integradora, que considera necessário que se aborde questões sociológicas no que diz respeito, principalmente, a sociologia musical, de maneira a integrar os indivíduos em contextos sociais mais amplos, promovendo assim sua ampla inserção na sociedade. Essa abordagem possibilita a integração do cidadão à diversidade de contextos sociais e parece promover uma realidade na qual o aluno pode ter uma dimensão mais ampla de seu próprio protagonismo.

Segundo essa orientação, é por intermédio do diálogo entre a identidade do indivíduo (HALL, 2006) e as definições que ele carrega sobre si que podemos realizar um esforço mais honesto no sentido de compreender quem é esse aluno e como ele se vê nesse emaranhado de referênciais.

Todas essas questões também colocam não somente o aluno em construção, bem como o professor e seus procedimentos (ABRAHAMS, 2005; FREIRE, 1979).

Os princípios preconizados pela pedagogia crítica, portanto, consistem em um amplo e constante questionamento sobre a própria prática. Todos esses elementos são interessantes para o processo educativo, ao passo que, o professor para auxiliar na construção do processo de ensino e aprendizagem tem que se despir de uma série de conceitos pré-estabelecidos e se apropriar de outros.

A pedagogia crítica, por causa de sua ampla utilização e interpretação por parte de autores de diferentes áreas, inclusive da Educação Musical, constitui, hoje, como defende Abrahams (2005), um conjunto de ideias muito amplo e complexo. No entanto, ela pode ser entendida, em sua estrutura básica, como um conjunto de ações que promove e encoraja os 
alunos a questionarem e a elaborarem ideias e conceitos sobre aquilo que aprendem. Essa definição sugere a complexidade e o caráter revolucionário de sua proposta, o que, no passado, gerou conflitos relacionados ao direito à liberdade, à educação e à conscientização.

A pedagogia crítica encerra, pois, uma postura combativa e de extremo comprometimento com as questões sociais e com o amplo desenvolvimento do indivíduo, encorajado-o a questionar, inclusive quando proibido ou coagido a não fazê-lo. Essa ação, não necessariamente, se encerra no que é proposto em sala de aula, mas se amplia para o cotidiano no qual o aluno está inserido e dialoga.

Não obstante, uma abordagem reflexiva não pode prescindir de um professor disposto a contestar sua própria maneira de lidar com os conceitos e as ideias estabelecidos. Não há possibilidade de uma pedagogia crítica se o professor não estiver disposto a ser posto a prova em suas certezas. Portanto, os professores precisam ser reflexivos de uma maneira interna, tentando compreender os seus próprios preconceitos, bem como o prisma ideológico pelo qual a sua realidade externa é classificada e compreendida (FREIRE, 1979).

No caso do ensino e aprendizagem musical, por exemplo, primeiramente, talvez seja indicado o questionamento acerca do próprio fazer musical afinal a música existe, e mais importante, possui finalidades. Esse questionamento propicia um mergulho profundo e amplo no próprio fazer musical.

A partir de uma ideia aparentemente simples, música para todos, subjaz uma série de desdobramentos reflexivos: qual música? Para quem? De quem? Interessaria então propiciar uma educação musical para toda a população. Nessa educação, a utilidade da música para fins estritamente comerciais seria contemplada de maneira parcial. Numa educação musical crítica, um dos objetivos poderia ser estimular a população a refletir sobre a própria utilidade da música na sociedade e os seus desdobramentos no seu cotidiano. As manifestações culturais artísticas, parecem apresentar, sobre o ponto de vista de produção do mercado musical, a ideia de que os elementos musicais artísticos e culturais são mais úteis como produtos para a indústria cultural, como produto de entrenimento e lazer do que como ferramentas de reflexão e de justiça social. A importância de uma educação musical, que dialogue com esses princípios, é um fator qualitativo.

Os padrões de identidade, de consumo e de absorção de informação impostos pela contemporaneidade propiciam um referencial musical por intermédio das mídias e de aparelhos eletroeletrônicos, que têm se apresentado com maior influência da escola e da 
academia. O aluno passa mais horas com seu celular, ouvindo música, no computador, acessando dados, ou assistindo a televisão do que em sala de aula. O volume de dados despejado sobre esse alunos, diariamente, parece ser maior e mais contínuo a cada dia. A sala de aula parece absorver uma pequena fração desses dados, mas ainda é a trincheira de transformação de dados em conhecimentos.

O primeiro passo para conscientizar e transformar a educação, acredito que seja dialogar e discutir com o aluno a noção de que o fazer musical não é exclusivo de privilegiados (FREIRE; SHOR, 1986) ou uma ação desenvolvida por seres excepcionais. Nesse sentido, o conhecer-se e a descoberta da própria musicalidade podem propiciar, para o aluno, uma consciência acerca de seu próprio potencial para o fazer musical. As atividades em salas de aulas, com o devido planejamento, podem gerar o início do processo desejado.

Com a intensificação do processo de globalização (SANTOS; 2002), as características particulares e as necessidades das comunidades locais com suas demandas específicas, ganha grande relevância na educação. Nesse contexto, Arroyo (2002) defende que o ensino de música nas escolas é um desafio complexo, pois propõe tanto o olhar para muitas músicas quanto o olhar para muitas pedagogias musicais.

No próximo tópico, apresento e descrevo as etapas e os resultados do levantamento de trabalhos e estudos sobre pedagogia crítica e educação musical realizado.

Com relação aos procedimentos realizados para o levantamento de literatura referente à pedagogia crítica e à educação musical, após a definição dos objetivos da pesquisa, relacionou-se as palavras centrais da temática de estudos com termos e conceitos que estabelecessem uma coerência entre os descritores de busca e a delimitação de trabalhos para a fundamentação teórica. Nessa etapa, os descritores "educação musical e conscientização", "pedagogia crítica e educação musical" e "critical pedagogy and music education" foram utilizados na busca.O levantamento foi realizado nos mecanismos de busca Google acadêmico, Revista da Associação Brasileira de Educação Musical (ABEM) e no banco de teses e dissertações da Comissão de Aperfeiçoamento Pessoal do Nível Superior (BDT/CAPES).

Dada a definição dos objetivos da pesquisa, a delimitação do campo teórico foi gradualmente sendo erigida. Na medida em que se avançou na complexidade das questões, bem como, na expansão das referências bibliográficas, determinados autores se mostraram mais pertinentes. 
A escrita de Paulo Freire (1979) é suporte pedagógico recorrente no levantamento da presente literatura. Dos conceitos que, efetivamente, contribuem para o aporte teórico deste trabalho, a produção de literatura relacionada a Paulo Freire se mostra efetiva.

A partir do conceito de conscientização (FREIRE, 1979), optou-se por um descritor que pudesse abranger dois grandes campos: "educação musical e conscientização" entre aspas. Devido a relevância da obra de Freire para a área de educação, houve a necessidade de se restringir o termo conscientização o associando à educação musical, para maior delimitação da pesquisa. Dito isto, o quadro 1 foi elaborado com os descritores e quantitativo de resultados encontrados na busca:

QUADRO 1: LEVANTAMENTO - ESTADO DO CONHECIMENTO

\begin{tabular}{|c|c|c|}
\hline BANCO DE BUSCA & PALAVRAS-CHAVES & RESULTADO \\
\hline Google Acadêmico & "Educação musical" e "conscientização" & 1630 \\
\hline Revista ABEM & "Educação musical" e "conscientização" & 1 \\
\hline Google Acadêmico & "Educação musical e conscientização" & 0 \\
\hline Revista ABEM & "Educação musical e conscientização" & 0 \\
\hline $\begin{array}{c}\text { Banco de teses e } \\
\text { dissertações da CAPES }\end{array}$ & $\begin{array}{c}\text { "Educação musical e conscientização" (área } \\
\text { Educação Musical) }\end{array}$ & 81 \\
\hline Google acadêmico & "Pedagogia crítica" e "educação musical" & 209 \\
\hline Revista ABEM & Pedagogia crítica e educação musical & 3 \\
\hline Revista ABEM & "Pedagogia crítica" e "educação musical" & 0 \\
\hline Google acadêmico & "Pedagogia crítica e educação musical" & 1 \\
\hline Revista ABEM & "Pedagogia crítica e educação musical" & 0 \\
\hline $\begin{array}{c}\text { Banco de teses e } \\
\text { dissertações da CAPES }\end{array}$ & "Pedagogia crítica" e "educação musical" & 81 \\
\hline $\begin{array}{c}\text { Banco de teses e } \\
\text { dissertações da CAPES }\end{array}$ & "Pedagogogia crítica e educação musical" & 0 \\
\hline \begin{tabular}{c} 
Google Acadêmico \\
\hline
\end{tabular} & "Critical pedagogy and music education" & 9 \\
\hline
\end{tabular}

Fonte: Autor

Para leitura e análise de trabalhos foram considerados os resultados da expressão completa entre aspas, uma vez que optei pela correlação entre a busca e a obtenção de resultados específicos ou a expressão exata. Isto, porque, inicialmente, os resultados com a busca aberta, sem aspas, foram muitos, diversificados e divergentes do tema, com exceção da busca na Revista da ABEM. Os resultados mais específicos, nos demais sites de busca, surgiram com a expressão exata e, posteriormente, com a mesma expressão em língua inglesa.

O levantamento realizado apresentou os resultados apresentados no Quadro 1. Desses foram selecionados os títulos mais adequados à temática desta revisão: 1 trabalho para a 
expressão exata, "pedagogia crítica e educação musical", 2 para Pedagogia crítica e educação musical na Revista da ABEM e 8 para a expressão em inglês, "critical pedagogy and music education". É importante destacar que na busca efetuada os trabalhos se repetiam. No âmbito das teses e dissertações, os trabalhos encontrados não discutiam a temática, objeto deste estudo, sendo desconsiderados na revisão. No Quadro 2, apresento a relação de títulos e autores dos textos selecionados entre os trabalhos encontrados.

Os trabalhos encontrados foram organizados, lidos e classificados por temas, aportes teóricos, metodologia e resultados.

\section{QUADRO 2: RESULTADOS AUTORES E TÍTULOS}

\begin{tabular}{|c|c|}
\hline Autor & Título do Texto para "Pedagogia Crítica e Educação Musical" \\
\hline $\begin{array}{l}\text { MORAES, } \\
\text { Abel (2006) }\end{array}$ & $\begin{array}{l}\text { Multifrenia na educação musical: diversidade de abordagens pedagógicas e } \\
\text { possibilidades para as profissões da música }\end{array}$ \\
\hline $\begin{array}{l}\text { ABRAHAMS, } \\
\text { Frank (2005) }\end{array}$ & Aplicação da Pedagogia Crítica ao ensino e aprendizagem de música \\
\hline Autor & Título do Texto para "Critical Pedagogy and Music Education" \\
\hline $\begin{array}{l}\text { ABRAHAMS, } \\
\text { Frank (2007) }\end{array}$ & Critical pedagogy in the community music education programmes of Brazil \\
\hline $\begin{array}{c}\text { PHILPOTT, } \\
\text { Chris; } \\
\text { SPRUCE, Gary } \\
\text { (2012) }\end{array}$ & Debates in music teaching \\
\hline $\begin{array}{l}\text { SPRUCE, Gary } \\
(2012)\end{array}$ & Musical knowledge, critical consciousness and critical thinking \\
\hline $\begin{array}{c}\text { KASCHUB, } \\
\text { Michele } \\
(2009)\end{array}$ & $\begin{array}{l}\text { Critical pedagogy for creative artists: Inviting young composers to engage in } \\
\text { artistic social action }\end{array}$ \\
\hline $\begin{array}{c}\text { GIACOMELLI, } \\
\text { Megan } \\
(2012) \\
\end{array}$ & $\begin{array}{l}\text { Theorising Improvisation as a form of Critical Pedagogy in Ontario Public } \\
\text { School Music Curricula }\end{array}$ \\
\hline $\begin{array}{l}\text { MIETTINEM, } \\
\text { Laura } \\
(2010) \\
\end{array}$ & Music, media and social critique \\
\hline $\begin{array}{c}\text { JOHANSSON, } \\
\text { Karin } \\
(2010)\end{array}$ & $\begin{array}{c}\text { Crossing borders: Nordic research in music education in an international } \\
\text { perspective. }\end{array}$ \\
\hline
\end{tabular}

Fonte: Autor

Após os resultados obtidos, os textos foram agrupados por subtemas. Dentre os resultados, um dos títulos foi excluído por se tratar de um livro que reúne uma coletânea de trabalhos de autores que discutem os mais variados assuntos. Os capítulos desse livro são apresentados como artigos distintos. Para essa síntese foi elaborado um terceiro quadro no 
qual, por intermédio dos resumos dos textos, foram organizados os subtemas, autor e título. Assim, no quadro 3, temos o tema Abordagem Pedagógica - metodologia de ensino dividido nos subtemas Abordagem Pedagógica e Currículo e Filosofia da educação: conceito e epistemologia da pedagogia crítica.

QUADRO 3: ABORDAGENS TEMÁTICA - NOME DO TRABALHO-

\begin{tabular}{|c|c|c|}
\hline \multicolumn{3}{|c|}{ Diversidade de Abordagem Pedagógica-Metodologia de Ensino } \\
\hline SUBTEMA & AUTOR/ANO & TÍTULO \\
\hline \multirow{7}{*}{$\begin{array}{l}\text { Abordagem } \\
\text { pedagógica } \\
\text { e currículo }\end{array}$} & $\begin{array}{l}\text { MORAIS, Abel } \\
\text { (2006) }\end{array}$ & $\begin{array}{l}\text { Multifrenia na educação musical: diversidade de } \\
\text { abordagens pedagógicas e possibilidades para as } \\
\text { profissões da música. }\end{array}$ \\
\hline & $\begin{array}{l}\text { ABRAHAMS, Frank } \\
\text { (2005) }\end{array}$ & $\begin{array}{c}\text { Aplicação da Pedagogia Crítica ao ensino e } \\
\text { aprendizagem de música. }\end{array}$ \\
\hline & $\begin{array}{l}\text { ABRAHAMS, Frank } \\
\text { (2007) }\end{array}$ & $\begin{array}{c}\text { Critical pedagogy in the community music education } \\
\text { programmes of Brazil }\end{array}$ \\
\hline & $\begin{array}{c}\text { SPRUCE, Gary } \\
(2012)\end{array}$ & $\begin{array}{l}\text { Musical knowledge, critical consciousness and critical } \\
\text { thinking }\end{array}$ \\
\hline & $\begin{array}{l}\text { KASCHUB, Michele } \\
\text { (2009) }\end{array}$ & $\begin{array}{l}\text { Critical pedagogy for creative artists: Inviting young } \\
\text { composers to engage in artistic social action }\end{array}$ \\
\hline & $\begin{array}{l}\text { GIACOMELLI, } \\
\text { Megan (2009) }\end{array}$ & $\begin{array}{l}\text { Theorising Improvisation as a form of Critical } \\
\text { Pedagogy in Ontario Public School Music Curricula }\end{array}$ \\
\hline & $\begin{array}{l}\text { JOHANSSON, Karin } \\
\text { (2010) }\end{array}$ & $\begin{array}{l}\text { Crossing borders: Nordic research in music education } \\
\text { in an international perspective. }\end{array}$ \\
\hline \multirow{4}{*}{$\begin{array}{l}\text { Filosofia da } \\
\text { educação: } \\
\text { conceito e } \\
\text { epistemologi } \\
\text { a da } \\
\text { pedagogia } \\
\text { crítica }\end{array}$} & $\begin{array}{l}\text { SPRUCE, Gary } \\
\text { (2012) }\end{array}$ & $\begin{array}{l}\text { Musical knowledge, critical consciousness and critical } \\
\text { thinking }\end{array}$ \\
\hline & $\begin{array}{l}\text { GIACOMELLI, } \\
\text { Megan (2009) }\end{array}$ & $\begin{array}{l}\text { Theorising Improvisation as a form of Critical } \\
\text { Pedagogy in Ontario Public School Music Curricula }\end{array}$ \\
\hline & $\begin{array}{l}\text { MIETTINEM, Laura } \\
\text { (2010) }\end{array}$ & Music, media and social critique \\
\hline & $\begin{array}{l}\text { MORAIS, Abel } \\
\text { (2006) }\end{array}$ & $\begin{array}{l}\text { Multifrenia na educação musical: diversidade de } \\
\text { abordagens pedagógicas e possibilidades para as } \\
\text { profissões da música. }\end{array}$ \\
\hline
\end{tabular}

Fonte: Autor

Os resultados obtidos foram relacionados às duas categorias definidas no quadro 3. Tal categorização adveio da análise do conteúdo dos textos e visou propiciar uma perspectiva analítica em que se pudesse mapear as distintas situações que os textos se referem. As discussões levantadas pelas pesquisas apresentaram ainda, trabalhos que podem dialogar com as duas categorias estabelecidas. Os termos contidos no referencial teórico dos trabalhos: pensamento crítico, pedagogia crítica e conscientização são termos recorrentes. 
Paulo Freire apresenta-se como referencial do texto de Moraes (2006) que relata tendências culturais da pós-modernidade e algumas de suas consequências nos âmbitos social, psicológico, cultural e acadêmico, relacionando-as com o mercado de trabalho e a formação profissional em música. A palavra multifrenia é o termo utilizado pelo autor que descreve a perda de identidade devido a sobrecarga de informações e à ampliação de novas possibilidades que estão relacionadas a uma saturação proveniente do excesso de informações. No contexto brasileiro, é possível ainda apontar revezes de estrutura e de sobrecarga de trabalho para o professor. As novas possibilidades se dão pelas transformações sociais, históricas e tecnológicas.

A pedagogia crítica, como uma abordagem emergente na educação musical é questionada a partir de um ponto de vista estético da educação musical e analisada quanto a seus objetivos, possibilidades e limites (MORAES, 2006). O autor objetiva, com esse texto, uma reflexão sobre a construção do campo da educação musical e sobre os novos rumos da formação profissional em música. Em seu artigo, Moraes (2006) apresenta uma abordagem transversal na categorização proposta que aborda tanto questões concernentes a pedagogia crítica quanto questões da psicologia. Ele tenta estabelecer um diálogo entre essas áreas. As possibilidades são diversas tanto em relação à abordagem, saberes, conteúdos e currículo, uma vez que a educação musical se encontra em expansão de seu campo de atuação e dialoga com questões não musicais. Os indivíduos, os contextos sociais, culturais e de identidade, bem como, questões de afetividade e psicológicas têm sido observadas, cada vez mais, por pesquisadores da área. A conclusão se dá no sentido que deve-se analisar todo esse contexto para compreender melhor o trabalho do professor.

O artigo de Abrahams (2007) analisa aulas de música em projetos sociais no Brasil. Ele dialoga com a pedagogia crítica de Freire, especificamente, o livro A pedagogia do Oprimido. $\mathrm{O}$ artigo discute e divulga metodologias de ensino e aprendizagem musical que visam à transformação da realidade social a partir dos preceitos de Freire nas localidades do Rio de Janeiro, Alvorada, Recife e São Caetano.

Nessa mesma temática, com abordagem pedagógica e currículo, na literatura internacional, Spruce (2012), em capítulo de livro, discute o pensamento crítico em uma perspectiva metacognitiva, ou seja, o pensamento sobre o próprio pensamento é analisado. Ele estabelece relações entre o pensamento crítico e a ideia de Freire sobre a conscientização, o que promove transformações. Ou seja, a compreensão da dimensão social e política 
transforma os indivíduos e os indivíduos transformam o contexto social. O autor observa que a educação musical pode transformar a situação sócioeconômica e promover a conscientização dos alunos, ao estimular que eles questionem a sua própria realidade. Aqui, parece que o exercício metacognitivo reside na perspectiva de que os atores do processo de ensino e aprendizagem musical, ao resignificarem sua própria realidade, questionam, também, a forma como é feito o questionamento, o que questionam e com qual objetivo.

O livro, organizado por Philppot Spruce (2012), trata de um seminário internacional no qual há um amplo debate sobre diversas perspectivas e abordagens concernentes à pedagogia da educação musical e da filosofia da educação.

Em artigo da ABEM, Aplicação da pedagogia crítica ao ensino e aprendizagem de música, Abrahams apresenta sua experiência docente sob perspectiva duma Pedagogia Crítica para o Ensino de Música- PCEM (ABRAHAMS 2005). Nesse artigo, há uma profunda reflexão sobre as ações que envolvem o ensino de música. Tais ações não estão necessariamente ligadas às realidades de países com problemas sociais crônicos ou às situações socioeconômicas delineadas; a abrangência da pedagogia crítica encontra-se no mundo. Assim, o autor elabora uma abordagem pedagógica para o ensino de música que dialoga fortemente com o conceito de conscientização de Freire (1979) e propõe desdobramentos interessantes como:

A Pedagogia Crítica para a Educação Musical procura identificar as possibilidades na sala de aula, oferecendo uma oportunidade para conectar a "palavra ao mundo" através de sua urgência inflexível de transformação.(ABRAHAMS, 2005, p. 68)

Intenta ainda que os alunos se tornem melhores músicos e sejam mais musicais. $\mathrm{O}$ autor indica que uma ação efetiva deva atuar desde a postura crítica do professor, passando por uma abordagem de planejamento mais fluido.

Tanto por meio de uma abordagem pedagógica e de currículo quanto por meio de uma análise epistemológica e conceitual, segunda temática do Quadro 3, a pedagogia crítica, sob perspectiva teórica dos trabalhos de Freire, é o alicerce conceitual dos trabalhos desenvolvidos. Ao promover a educação com uma abordagem da pedagogia crítica e da conscientização, o aluno reflete sobre aquilo que aprende e questiona sua própria condição a partir do exercício, não obstante, o professor se vê obrigado a estar em constante exercício 
crítico acerca do próprio ofício, o que propicia uma constante melhoria e reflexão sobre a própria educação e a pedagogia.

$\mathrm{O}$ estado do conhecimento realizado, embora ainda restrito, pela amostragem e tipos de argumentação indicam que esta pesquisa não pode prescindir da investigação dos conceitos iniciados com Freire e da necessidade de consultar abordagens e análises mais contemporâneas sobre eles.

O tema pedagogia crítica e educação musical mostrou ser um campo de interesse de autores de diferentes países e apresenta uma tendência de crescimento devido sua atualidade e, consequente, ferramenta teórica para pensar a prática educativa. A pedagogia crítica é uma área de relevante extensão no campo da educação e em crescente estudo na Educação Musical

O termo pedagogia crítica aparece como um elemento que aponta para outros como currículo e metodologia de ensino. A pedagogia crítica parece alimentar a base conceitual dos trabalhos apresentados e, concomitantemente, apresenta um revigoramento ao dialogar com outros contextos de aprendizagem como o da educação musical no qual o fator social e político deve ser observado e refletido. Tal interpretação contempla, de certa forma, inúmeras outras referências a Freire, uma vez que ele é precursor dos questionamentos e da autonomia crítica em sua obra.

A pedagogia crítica na educação musical aponta para práticas e um contexto pedagógico em que é necessário o exercício dialógico constante entre as especificidades da educação musical e as contribuições teóricas e práticas de outras áreas de conhecimento.

Afinal, hoje, o contexto de discussão da pedagogia crítica é distinto do contexto de sua origem. Curiosamente, certos axiomas do pensamento de Freire como a conscientização e a pedagogia crítica despertam, renovadamente, interesse dos pesquisadores no Brasil e em diferentes países.

As abordagens interpretativas e as discussões acerca da pedagogia crítica, bem como a discussão sobre uma filosofia da educação musical e seu campo empírico constituem um interessante e denso exercício analítico e reflexivo que esta revisão não esgota. Os trabalhos parecem utilizar sob diferentes prismas a obra de Freire e também o pensamento crítico de uma forma geral. Ele se propõem a correlacionar o pensamento crítico aos elementos que investigam seja dentro ou fora de sala de aula. A realidade dos currículos, as dimensão psicológica, a realidade do professor e do alunos, todos parecem apresentar uma possibilidade 
de diálogo com o pensamento crítico, sua natureza questionadora e transformadora por intermédio da reflexão ativa. 


\section{O PERCURSO METODOLÓGICO DAS AULAS DE MÚSICA}

Esta pesquisa, ao descrever e analisar os desafios e possibilidades de aulas de música para transformar as referências musicais cotidianas dos alunos, não as negando, mas expandindo seu referencial de repertório, aponta para um estudo de natureza pedagógica, qualiquantitativo e de caráter exploratório. Procedeu-se com análise de conteúdo, redução de dados e organização de categorias associados à amostragem estatística como encontremos em Bauer e Gaskell (2002). Tais elementos serão abordados mais detalhadamente na parte subsequente que trata dos questionários diagnósticos.

Considera-se esta pesquisa qualitativa e de natureza pedagógica porque envolve o contexto escolar, ambiente natural em que as impressões, concepções e ações dos sujeitos envolvidos são consideradas objeto de estudo. Os sujeitos desta pesquisa são os alunos do oitavo ano A do Centro de Ensino Fundamental número 5 do Paranoá (CEF 5 Paranoá) nas aulas de Artes - Música. A abordagem quantitativa está associada aos dados coletados por meio de questionários que apresentam um perfil sócioeconômico e musical dos estudantes. Lankshear e Knobel (2008, p.16) destacam o interesse da pesquisa pedagógica na busca por um equilíbrio entre os estudos quantitativos e qualitativos.

A pesquisa é pedagógica também porque nasce da problematização da minha prática docente (como exposto na Introdução desta monografia) e se refere às situações vivenciadas na interação com uma turma de estudantes. Como professor, questionar minha prática e investigá-la é uma necessidade para promover uma educação transformadora. Assim, esta pesquisa reflete tanto a minha atuação como docente quanto a minha inquietação como professor. Nas palavras de Lankshear e Knobel, os propósitos e os ideias da pesquisa pedagógica podem ser agrupados em torno de dois conceitos fundamentais:

[...] um deles diz respeito a melhorar a percepção do papel e da identidade profissional dos professores. O outro é a ideia de que o envolvimento com a pesquisa pedagógica pode contribuir para um ensino e uma aprendizagem de melhor qualidade nas salas de aula. (2008, p.14)

Este estudo reflete, portanto, as possibilidades e limites do professor investigador de sua própria prática: o olhar distinto e curioso sobre as ações cotidianas, o refletir sobre suas ações e interações com os alunos e o questionar a escola e sua própria ação como educador. A 
experiência vivenciada durante esse projeto vão ao encontro das palavras de Garrido e Bzerzinski (2008):

[...] ser professor investigativo significa buscar esclarecer os problemas que ele e seus colegas vivenciam no cotidiano escolar, problemas de início confusos e polêmicos, porque envolvem pessoas, valores, crenças, interesses, freqüentemente em conflito; significa aprofundar a compreensão dessas questões, procurando ouvir e respeitar os diferentes atores (professores, alunos, pais), para propor alternativas aceitáveis pelo grupo, a serem experienciadas, analisadas e aperfeiçoadas, tornando o ensino pesquisa, pesquisa na ação. nesse contexto, o papel do professor ganha expressão e a escola passa a ser um espaço privilegiado de formação profissional. (GARRIDO; BZERZINSKI, 2008, p.155).

Sob essa perspectiva, essa pesquisa foi realizada. Cabe aqui destacar as dificuldades enfrentadas para desenvolvê-la, uma vez que uma escola recém inaugurada sofre adversidades e desafios que interferiram no desenvolvimento das aulas e na coleta de dados. As turmas apresentavam um contingente flutuante de alunos e a configuração e organização da escola mudou várias vezes durante o processo de realização das atividades propostas.

A seguir apresento o campo empírico e os procedimentos metodológicos utilizados.

\subsection{A SELEÇÃO DA TURMA $8^{\circ}$ ANO A}

Para realização desta pesquisa pedagógica, selecionei a turma do $8^{\circ}$ ano A da Escola CEF 05 do Paranoá, sendo que ela foi escolhida devido às características dos estudantes, o que viabilizou a realização e coesão da pesquisa: a maioria dos alunos era repetente, porém não todos; o $8^{\circ}$ ano, por ser o penúltimo ano, dos anos finais do ensino fundamental, possibilitava uma maior interação com os alunos (eles já estavam adaptados a essa fase educacional); a turma era formada por alunos mais frequentes.

Inicialmente, foi realizado dois projetos pilotos com as turmas do nono ano, que, já demonstravam características de estudantes do ensino médio por causa, principalmente,da faixa etária. Apesar do oitavo ano apresentar alunos repetentes na faixa de 16 anos, procurei trabalhar com todos para não descaracterizar o contexto juvenil dos jovens que frequentam o CEF 05 do Paranoá. O interessante é que o $8^{\circ}$ ano A apresenta a menor faixa etária média. Isto, também, auxilia a reflexão sobre a situação dos anos finais do ensino fundamental como um todo e não, tão somente, com os estudantes repetentes e que estão na antesala do Ensino Médio, EJA ou desistência. 


\subsection{AS FONTES DE PESQUISA E O PLANEJAMENTO DAS AULAS}

As aulas de música propostas consistiram em quatro etapas aplicadas em duas aulas de Arte e uma aula de Projeto Disciplinar (PD), o que compreendeu doze aulas e o período de quatro semanas. As quatro etapas foram assim dispostas:

1) Aplicação de questionário diagnóstico Socioeconômico, discussão com a turma e análise dos dados coletados;

2) Aplicação do questionário de Preferências Musicais, discussão com a turma e análise dos dados coletados;

3) Aplicação do questionário de Preferências e Práticas Musicais, discussão com a turma e análise dos dados coletados;

4) Composição Musical e análise;

5) Apreciação Musical - análise crítica: elementos musicais e contexto sociocultural;

A coleta de dados envolveu além dos questionários, outras fontes como: planejamento de aulas e anotações das aulas; áudios das atividades; documentos da escola, documentos legais da SEDF.

\subsubsection{As atividades piloto}

Como dito anteriormente, foram realizados dois projetos pilotos com as turmas do $9^{\circ}$ ano, com o intuito de avaliar a sequência de aulas previstas e a receptividade da turma. Durante a realização dos pilotos foram observadas dificuldades e desafios para desenvolver a proposta.

A recente inauguração da escola e seu caráter precário de funcionamento influenciaram as ações realizadas, o que demandou ajustes nas aulas. A observação de falhas iniciais e de inconsistências encorajaram o aprimoramento do planejamento das aulas, uma vez que a análise prévia do andamento dos trabalhos fez com que houvesse a necessidade de desenvolver procedimentos mais amplos e melhor estruturados.

Os passos iniciais, que consistiram em levantamneto da realidade socioeconômica, pesquisa de preferências e de práticas musicais foram mantidas. As mudanças mais efetivas se deram na maneira e na ordem em que as discussões eram trabalhadas.Nos projetos piloto houve ainda pouco tempo para apresentação e reflexão sobre a composição musical. As 
experiências piloto demonstraram a relevância da proposta para os estudantes e as possibilidades desse tipo de aulas de música para projetos a longo prazo: um semestre ou um ano letivo. Da mesma forma, as aulas podem ser executadas em seu formato menor, em módulos de 4 semanas.

Dentre os problemas apresentados na realização dos projetos pilotos se destacam: 1) estrutura física e organizacional (tempo) da escola; 2) a dificuldade de se trabalhar com salas ambiente, pois o número de alunos mudava diariamente, assim como, a localização das salas;3) problemas estruturais de segurança; 4) ausência de ventilação nas salas; 5) falta de abastecimento na escola e 6) quedas de energia ocasionadas por sabotagem de alunos. Esses fatores dificultaram muito a execução do primeiro projeto piloto.

Tais dificulades exigiram o deslocamento das turmas pelos corredores estreitos, o que interferia nos planejamentos de aula, pois os deslocamentos geravam tumulto e desconcentravam a turma. O primeiro piloto gerou uma incossistência significativa, principalmente, pelo fato de que, durante as três semanas previstas, somente pouco mais de nove alunos estiveram presentes, fato provocado pela evasão e pela mudança de turma.

Com relação às salas ambientes, estas foram previstas para atender às especificidades das disciplinas, sendo algumas delas compartilhadas com os colegas de outras turmas. Esse tipo de organização atenderia, parcialmente, um espaço específico para aulas de música, contudo a direção da escola reconheceu a inviabilidade do deslocamento de quatrocentos alunos em andares distintos, cujo único acesso às salas de aula é feito por escadas e corredores estreitos. Essa prática ocasionou um pesadelo logístico para escola: os alunos matavam aula; perambulavam pelos corredores e os professores perdiam muito tempo para iniciaras aulas. Assim, a direção determinou a extinção das salas ambiente. O fato gerou questionamento da minha parte, pois tal situação indicava, apesar do problema legítimo de deslocamento, prejuízo pedagógico.

Em um segundo piloto, com a escola sem as salas ambiente e com o projeto de aceleração das turmas de $6^{\mathrm{a}}$ ano e de $8^{\circ}$ ano em andamento, a melhor organização da escola propiciou, após os devidos ajustes, a aplicação das aulas de música na turma do $9^{\circ}$ ano $\mathrm{P}$. Esta turma era constituída apenas de alunos repetentes que foram promovidos ao $9^{\circ}$ ano no segundo semestre, após criteriosa análise das notas e do comportamento dos melhores alunos do $8^{\circ}$ ano no primeiro semestre. $\mathrm{O} 9^{\circ}$ ano $\mathrm{P}$ apresentava uma mudança profunda de comportamento, uma vez que os alunos tiveram a possibilidade de cursar dois anos em um, o 
que viabilizaria o ingresso no Ensino Médio no ano seguinte. Essa opção estimulou os alunos e elevou a sua auto estima.

O critério para selecionar essa turma para o projeto consistiu no fato de os estudantes fazerem parte de um processo de empoderamento por intermédio da aceleração escolar e pela grande adesão às atividades e às discussões propostas para os alunos.

$\mathrm{Na}$ aplicação do segundo projeto piloto, procurei um aprofundamento e um aprimoramento das atividades, bem como, pude observar que os alunos respondiam muito bem quando eu intercalava o diálogo com exemplos musicais executados em tempo real. Dentre as atividades, foi bastante proveitoso quando exemplifiquei com o pandeiro os ritmos mais citados como de preferência pelos alunos. Eu pude observar que a atenção dos alunos estava associada ao reconhecimento das minhas habilidades com os conceitos práticos e teóricos da música. Nessa interação, observei, subjetivamente, uma maior empatia dos alunos para comigo, o que me encorajou a participar da etapa de composição executando células rítmicas ao vivo.

Essa aproximação possibilitou que realizássemos uma execução da composição, gravada em áudio, tendo como base rítmica um ostinato pré gravado e enviado para seus celulares. Outro fator que muito contribuiu foi o avanço da revisão de literatura e o contato com a bibliografia que fundamenta esta pesquisa. $\mathrm{O}$ meu amadurecimento teórico fez com que redobrasse a atenção e a didática em sala.

Entretanto, por causa da minha inexperiência em coletar dados de maneira sistemática e efetiva, os procedimentos metodológicos apresentavam falta de rigor científico, o que determinou, então, uma autocrítica, no sentido de perceber que apesar de todos os esforços, estes não apresentavam o nível de exigência para caracterizar a validade da pesquisa, o que culminou na decisão de aprimorar o projeto e aplicá-lo em um terceiro momento.

Por fim, delimitei o formato e a sequência de ações a serem realizadas, bem como, busquei obter dados de forma mais consistente para validar o estudo. A terceira turma selecionada, como apresentado anteriormente, foi o $8^{\circ}$ ano A com 17 alunos repetentes.

As aulas de música foram realizadas, então, no período de março a maio de 2016.

\subsubsection{Os questionários diagnósticos: primeira atividade}

No $8^{\circ}$ ano $\mathrm{A}$ foram aplicados três questionários diagnósticos em momentos distintos como apresentado no item 3.2. Vale ressaltar que alguns alunos matriculados na sala de aula, 
32 ao total, ora mais ora menos, não responderam aos questionários, pois não estavam presentes em todas as etapas da sua aplicação e das dinâmicas realizadas. Assim, os respondentes são uma parte da turma, os mais assíduos.

$\mathrm{O}$ primeiro deles, questionário Socioeconômico (Apêndice B) consistiu de 22 perguntas, abertas (16) e fechadas (6), que procuraram estabelecer critérios gerais concernentes ao quesito socioeconômico: idade; quantidade de pessoas na residência; identidade racial; se possuia filhos; se trabalhava; nacionalidade; o local de moradia; se tinha acesso à internet; horário que levanta para ir à escola; o tempo de deslocamento até a escola; opinião sobre a importância dos estudos para sua vida; grau de escolaridade desejado; opinião sobre a escola para a comunidade; opinião sobre a avaliação da aprendizagem; suas experiências positivas e negativas com relação à escola; que atividades gostaria de participar na escola; como ele, o aluno, poderia contribuir com o ambiente escolar; como ele se via; como foi o seu desempenho no ano anterior e quais eram suas expectativas para 2016. O levantamento socioeconômico pode apresentar benefícios significativos, uma vez que é propiciado ao aluno uma oportunidade para ele se manifestar sobre suas aspirações e falar um pouco de sí.

Com o questionário diagnóstico, o professor, por sua vez, possui valiosa amálgama de informações sobre os estudantes para eventual consulta e estudo. Esse tipo de levantamento faz com que o professor possa ter uma noção mais precisa da realidade e particularidades de cada aluno, uma vez que, dado ao seu regime de trabalho e à carga horária exigida, nem sempre é possível uma maior aproximação entre professor e alunos.

A aplicação do questionário adotou os seguintes procedimentos. Primeiramente, iniciou-se diálogo sobre a importância de todos se conhecerem melhor. Nas aulas inaugurais, já havia ocorrido uma breve apresentação. Foi sugerida a necessidade de aprofundar a conversa das primeiras aulas. Os alunos concordaram com a minha proposta. Em uma roda de conversa, iniciei uma breve fala me apresentando, dizendo quem era, o que fazia, o que gostava de fazer fora da escola e onde morava. Então, sugeri que cada aluno, também, se manifestasse dizendo seu nome, o que gostava de fazer, como cada um se percebia e como percebiam a escola. Este diálogo introduziu a aplicação do questionário socioeconômico, respondido em 20 minutos. O questionário foi aplicado por mim. Cada aluno recebeu-o impresso e o respondeu durante a aula. Após essa etapa, lí algumas respostas selecionadas por mim para não expor nenhum aluno. Após o primeiro momento do questionário, iniciei a roda 
de conversa sobre a importância de se conhecer e conhecer ao outro, bem como, foi destacada as diferenças observadas entre as impressões dos alunos, sobre si e a escola, relatadas nos questionários. Foi aberta a possibilidade de fala aos alunos. A conversa durou 45 minutos. $\mathrm{O}$ objetivo foi trazer a escrita, a fala dos alunos e as suas impressões como protagonistas do contexto escolar.

A análise do questionário foi realizada com ajuda do google drive - formulários. Os questionários foram numerados e as respostas organizadas por questões de maneira à preservar o anonimato dos participantes. Elas foram introduzidas no aplicativo manualmente para que este organizasse as respostas. Assim, foram inseridos 18 questionários organizados na ordem do Q1 ao Q18. Esse procedimento intentou manter um padrão ético de não exposição dos respondentes, preservando o seu anonimato e a sua individualidade. Os alunos, antes de responder ao questionário, foram orientados quanto aos procedimentos éticos e quanto ao anonimato das respostas.

Em um segundo momento, foram aplicados os outros dois questionários relativos às preferências musicais dos alunos e às suas práticas musicais. Um deles, o segundo questionário (Apêndice C), mais subjetivo, foi constituído por 8 questões abertas em que os alunos apontavam sua opinião sobre a Arte, a Música, as músicas da moda e as suas preferências musicais, citando músicas que gostavam e justificando seu gosto. $\mathrm{O}$ maior objetivo desse instrumento era identificar quais eram a músicas que os alunos mais ouviam e se suas preferências coincidiam com as músicas da moda.

O último questionário, terceiro (Apêndice D), complementa o anterior e é constituído por 17 questões fechadas sobre as preferências musicais (estilos conhecidos e do gosto musical), experiências, vivências, práticas e conhecimentos musicais, como, por exemplo: onde e como escutam música; se cantam; se tocam; se compõem e se já estudaram música. Esses dois questionários, o segundo e o terceiro, apresentam questões mais específicas concernente à aprendizagem musical e aos conhecimentos musicais prévios dos estudante, bem como, seus hábitos de interação com a música.

Como no questionário socioeconômico, as respostas foram inseridas no aplicativo google drive (formulário) e os questionários respondentes foram numerados e organizados por ordem de resposta. No segundo questionário, 19 alunos responderam, mas, no terceiro, 18 alunos participaram. Essa diferença de respondentes está relacionada com a flutuação de frequência dos alunos. 
Após a inserção das respostas dos participantes no formulário google drive, o aplicativo gerou planilha e gráficos baseados nos dados dos questionários que permitiram uma análise quantitativa e qualitativa. As questões fechadas receberam tratamento quantitativo referentes à maior ou menor incidência de respostas. $\mathrm{O}$ aplicativo do google drive fornece um resumo das respostas que facilita a descrição e interpretação desses dados. Contudo, para cruzamento de dados, a planilha do google drive foi baixada no formato excell/Office (xlsx) para elaboração de tabelas e gráficos para novas interpretações. Assim, na apresentação dos resultados, a análise cruzada de questões fechadas foram analisadas e apresentadas em forma de tabela (Apêndice E).

As questões abertas acessíveis no formato excell (xlsx) foram organizadas em tabelas no formato word (docx) (Apêndice F) para categorização (unidades de análise) sob perspectivada análise de conteúdo. Esta pode ser entendida como "um conjunto de vias possíveis nem sempre claramente balizadas, para a revelação - alguns diriam reconstrução — do sentido de um conteúdo”. (BAUER; GASKELL, p.216, 2002).

A análise inicou com a leitura das respostas às questões abertas. Apartir de uma categorização inicial, foram destacadas as unidades de análise para cada pergunta (Apêndice F). Posteriormente, foi realizada uma releitura dos dados considerando as categorias chaves e sua incidência nas respostas. Em cada uma dessas categorias foram associadas as respostas dos alunos, o que possibilitou a interpretação transversal dos dados. Segundo Bauer e Gaskell (2002, p. 217), "o termo unidade deve ser entendido como unidade de sentido porque as unidades compreendem, com muita frequência, mais de uma palavra”. A análise dessas unidades foram também submetidas a uma interpretação quantitativa, observando a incidência de cada uma delas nas respostas dos alunos. Bauer e Gaskell (2002, p.217) explicam que "uma vez agrupadas as unidades, o pesquisador que quer submete-las a um tratamento estatístico pode facilmente enumerar as palavras ou as frases". Realizados esses procedimentos, os dados foram interpretados e apresentados no capítulo 5 .

$\mathrm{Na}$ descrição dos resultados, o termo alunos deixa de ser utilizado de forma genérica e passa a ser utilizado com referência à cada um dos gêneros, ou seja, na forma masculina e na forma feminina uma vez que as meninas correspondem à 50\% dos respondentes.

As respostas dos questionários orientaram as atividades musicais que são descritas a seguir. 


\subsubsection{As Atividades Musicais}

As atividades musicais foram fundamentadas nos questionários, especialmente, os de preferências musicais como pode ser verificado nos resultados apresentados no capítulo 5 . Nas respostas, é possível verificar, mais uma vez, que as preferências não vão, necessariamente, ao encontro dos estilos e hits que estavam amplamente difundidos na ocasião. Assim, apesar das preferências individuais constituírem um mosaico diversificado, pude verificar que o ritmo Funk Carioca, Rap e Sertanejo figuram entre os estilos mais conhecidos. Esses dados e os outros resultados encontrados influenciaram a elaboração das atividades de composição e de apreciação musical.

Em sala de aula, as atividades realizadas foram sempre acompanhadas de exemplos musicais e práticos. Estes foram tocados "ao vivo" com pandeiro, baixo elétrico, voz e/ou percussão corporal. Essas atividades consistiram em: escuta musical, reprodução de elementos musicais escolhidos para serem fixados e exercitados, composição, apresentação musical coletiva e apreciação musical com discussão sobre os elementos musicais e extramusicais.

A composição musical coletiva foi a principal atividade proposta nas aulas de música realizadas em que a turma foi dividida em dois grandes grupos. O estilo, a temática, o conteúdo e a execução musical foram elaborados em conjunto. Na realização dessa atividade foi segurido aos alunos que compusessem um trecho musical relacionado com as suas preferências musicais, essas discutidas nas rodas de conversa e descritas nos questionários aplicados previamente. A composição foi efetivada em duas aulas, cada uma com 45 minutos.

Para desenvolver a composição, foi realizado um diálogo com a turma. A questão da diversidade foi debatida e o diálogo abordou os elementos musicais facilmente identificados no dia-a-dia. Ou seja, observar as situações, os elementos que percebemos na música e as inúmeras possibilidades de sua utilização nas diferentes linguagens como dramaturgia,

publicidade, cinema, televisão, artes em geral e a percepção dos estudantes sobre a comunidade, a escola e seus direitos e deveres. Foram ainda debatidos temas como respeito, amizade, solidariedade e crítica social.

Para efetivar a criação musical, foi gravada uma base rítmica nos celulares como proposto no diálogo alunos(as)-professor. $\mathrm{O}$ estilo, inicialmente, seria uma batida de $R A P$, porém um aluno, espontaneamente, propôs uma batida de Funk Carioca. Os(As) alunos(as) prontamente aderiram à sugestão. Cada grupo ficou com a base gravada no celular para 
comporem uma frase rítmico-melódica que se encaixasse na letra. Posteriormente, sugeri uma variação melódica. Os(As) alunos(as), então, executaram, coletivamente, a composição com a temática, o ritmo e a melodia propostos. $\mathrm{Na}$ execução, toquei junto com os(as) alunos(as), fazendo o ritmo no pandeiro.

Todo o processo criativo foi registrado em áudio (Apêndice H). O material sonoro apresenta boa qualidade de execução e o processo da composição está audível de maneira a comunicar o seu conteúdo.

Após a composição musical foi realizada uma aula de 45 minutos para apreciação musical, em que a composição dos alunos foi analisada e discutida com a audição e análise de músicas de estilos pouco conhecidos e pouco apreciados pelos alunos: samba, jazz, ópera e música orquestral. Dessa maneira, os exemplos musicais escolhidos e reconhecidos como composições relevantes foram analisados para que os(as) alunos(as) pudessem contrapor e dialogar com o exercício de composição da turma.

Para isto, após pesquisa e análise dos dados dos questionários diagnósticos e das atividades musicais realizadas, optei pela obra musical Ópera do Malandro de Chico Buarque de Holanda, musical baseado na Ópera dos três vinténs de Kurt Weill e Bertold Brecht, como objeto de análise e reflexão. Esta ópera, por sua uma vez, se baseia na ópera de Jonh Gay, The Beggar's Opera (Ópera dos Mendigos) de 1728. Essas composições foram trabalhadas de forma intertextual por Chico Buarque.

O estilo composicional utilizado por Chico apresenta recurso musical (arranjo, citações, paródias) que é interessante para explicar aos(às) alunos(as) tanto os conteúdos musicais quanto a crítica social que perpassa autores, obras, estilos e períodos musicais. Nesse sentido, postura crítica é um fator que pode denotar qualidade e atualidade da produção artística. 


\section{O CONTEXTO PEDAGógICO-MUSICAL: A ESCOLA E A COMUNIDADE}

A Região Administrativa do Paranoá, próxima a Brasília, integra o núcleo populacional do Distrito Federal ${ }^{4}$ (DF). Nos últimos anos, essa região vem sofrendo forte adensamento populacional, principalmente, com o surgimento da invasão do Itapuã $^{5}$ e de núcleos de apartamentos populares. Isto ocorre, entre outros motivos, pelo aumento populacional do DF como um todo.

O Paranoá, em sua estrutura urbana, possui 32 escolas; um hospital regional; um posto de saúde; um restaurante comunitário; uma rodoviária; uma Biblioteca Pública; um Batalhão de Polícia Militar; uma Companhia Regional de Incêndio do Corpo de Bombeiros; uma Agência do Trabalhador; um Departamento de Trânsito (Detran); e as seguintes agências bancárias: Banco do Brasil, Caixa Econômica, Bradesco, Itaú e Banco Regional de Brasília. Geograficamente, o Paranoá congrega uma grande extensão territorial e é considerada a segunda maior região rural do DF.

A Companhia de Planejamento do Distrito Federal (CODEPLAN) elaborou o seguinte documento:

A Vila Paranoá originou-se do acampamento dos pioneiros que trabalhavam na construção da Barragem do Lago Paranoá em 1957. Após o término da obra, os pioneiros permaneceram no local, e outros imigrantes ocuparam a área próxima à antiga vila, de forma desordenada. Em 1960, o acampamento abrigava cerca de três mil moradores em 800 barracos, assentados próximo à barragem do Lago Paranoá. Em 10 de dezembro de 1964, com a Lei ${ }^{\circ}$ 4.545, foi criada a Região Administrativa do Paranoá, porém, somente em 25 de outubro de 1989, com Decreto $\mathrm{n}^{\circ} 11.921$, foram fixados os novos limites e a transferência do assentamento para área definitiva do Paranoá. Após a fixação da Vila Paranoá, a área do antigo acampamento tornou-se o Parque Vivencial do Paranoá aprovado pelo Conselho de Arquitetura, Urbanismo e Meio Ambiente - CAUMA, em 1992, e instituído pelo GDF por meio do Decreto $\mathrm{n}^{\circ} 15.899 / 94$. Em 2015, a PDAD estimou a população urbana do Paranoá em 48.020 habitantes. (BRASÍLIA, 2015).

Outro fator relevante a acrescentar é a existência da invasão chamada Itapoã integrada ao Paranoá. O projeto para transformar essa invasão em Região Administrativa encontra-se em andamento. Segundo os dados da CODEPLAN, em 2015 estimava-se a população na

\footnotetext{
${ }^{4} \mathrm{O}$ Distrito Federal é dividido por .Regiões Administrativas sob responsabilidade de um "Administrador" nomeado pelo governador.

${ }^{5}$ Itapuã é uma invasão proveniente do Paranoá. Possui sérias restrições estruturais e exerce grande pressão de demanda dos serviços públicos sobre o Paranoá
} 
ordem de 68.000 habitantes. Essa configuração geográfica tem influência direta nesta pesquisa, pois determina um contexto socioeconômico diversificado, em que a demanda por vagas nas escolas do Paranoá apresenta-se em franca expansão. No período em que a pesquisa foi realizada, a população do Itapoã aumentou em dez pontos percentuais em números absolutos. O Paranoá por sua vez, aumentou por volta de quatro pontos percentuais. Esse contexto serve para ilustrar que, em um período de dois anos, a população aumentou em quinze pontos percentuais o que exerce demanda crescente na infraestrutura dos serviços públicos.

Tal demanda, invariavelmente, gera efeitos que ocasionam pressão sobre as escolas que precisam se adequar à demanda vigente. Ao término do ano de 2014, por exigência da população local, houve a solicitação à Gerência Regional de Ensino ${ }^{6}$ (GRE) de um novo prédio para abrigar os alunos excedentes de outras escolas, bem como, os alunos em defasagem escolar. Nesse sentido, o Conselho Comunitário exerceu pressão na GRE local para que um prédio comercial, vago, anteriormente ocupado por uma escola particular, fosse alugado pelo governo para receber esses alunos. O prédio encontra-se em uma zona central, na rua Transversal (rua perpendicular à avenida principal) do Paranoá, situado entre diversos bares e quadras conhecidas como zona de comércio ilícito. O ambiente hostil e favorável às drogas demandou uma mobilização dos professores, que redigiram carta informando à regional sobre a situação geográfica do prédio. Com a elaboração de requerimento especial, a escola passou a contar, sistematicamente, com a presença e apoio do batalhão escolar.

Estes fatores influenciam o processo de ensino e aprendizagem e o olhar sobre a escola e seus alunos. A precariedade física e humana encontrada, inicialmente, foi amainada pelos projetos e intervenções realizados ao longo do ano de 2015, o que contribuiu para uma sensível melhoria do ambiente escolar. Porém, esta melhoria somente surtiu efeito no ano de 2016. No período da pesquisa de campo, segundo semestre de 2015 (aplicação dos dois projetos pilotos) e primeiro bimestre de 2016, a escola estava em fase de transição e estruturação. Para melhor entender o processo de organização do espaço e tempo escolar, apenas para melhor elucidação e contextualização da realidade vivenciada, faço referência breve à situação inaugural da escola e detalho, mais demoradamente, o segundo momento que

\footnotetext{
${ }^{6}$ Gerência Regional de Ensino (GRE) é um órgão administrativo setorial, vinculado a Secretaria de Educação do Distrito Federal, que se distribui pelo Distrito Federal no intuito de estabelecer critérios educacionais análogos às Regiões Administrativas. Assim, como o Distrito Federal se divide em RAs a Secretaria se subdivide em GRAs.
} 
contextualiza a aplicação das ações que são analisadas nesta pesquisa como objeto de reflexão.

\subsection{SOBRE CONTEXTO ESCOLA-CIDADE: ALGUMAS REFLEXÕES}

A escola CEF 05 do Paranoá funciona no prédio onde, anteriormente, funcionava uma escola de ensino fundamental particular: Escola Barão do Rio Branco. Para adequar a realidade arquitetônica à necessidade de seus alunos, o estabelecimento de ensino deixou o prédio, alugado de um particular, para se estabelecer em um prédio novo em uma área mais distante, situado ao lado da Gerência Regional de Ensino do Paranoá (GRE Paranoá).

Nesse período, no final do ano de 2014, ao fazer a contagem de vagas/matrículas para a comunidade da região do Paranoá, a GRE constatou que haveria de ter que deslocar os alunos excedentes para uma outra regional de ensino (GRE Plano Piloto/Cruzeiro). Aqui se apresenta um relato informal da situação, mas de extrema importância para a compreensão do contexto de fundação do CEF 5 do Paranoá. O excedente de matrículas, por questão gerencial, eram identificados como os alunos que excediam a faixa etária para o Ensino Fundamental, devido a sucessão de reprovações. Eram alunos na faixa etária de 16 anos e que poderiam, caso o desejassem, se matricular no turno noturno. Nesse funciona a Educação de Jovens e Adultos (EJA). Assim, ante a situação apresentada, era importante considerar dois fatores: 1) o excedente de demanda em face à disponibilidade de oferta de vagas nas escolas da GRE do Paranoá; 2) a realocação, entre os alunos regularmente matriculados, dos chamados "alunos problema". Não é preciso um exercício muito burilado de reflexão para correlacionar a realidade de defasagem escolar com os eventuais problemas de disciplina, de baixa estima e de adequação desses alunos ao contexto escolar. Assim, muitos dos alunos que eram repetentes e seriam deslocados para uma escola em outra área do DF eram alunos de dificílimo trato, em sua maioria, no tocante à disciplina e à aprendizagem.

Dito isto, um agravante para a comunidade se apresentava: não havia mais vagas para muitos desses alunos, e eles teriam que depender de um transporte fretado da GRE para deslocamento até uma escola, em período parcial, o que estava em funcionamento e disponível para receber quase 1000 alunos. Importante destacar que, as escolas do Plano Piloto/Cruzeiro já se encontram superlotadas por que atendem à demanda excedente de outras regionais. Ao problema logístico apresentado somou-se à legítima angústia, por parte de 
alguns desses pais, com a perda do acompanhamento da vida escolar do seu filho, por causa da falta de proximidade com a escola. Não obstante, a perda pedagógica seria muito intensa. Pois, alunos deslocados de seu próprio contexto e comunidade teriam que sofrer o deslocamento diário e ter que absorver mais um elemento de estranhamento em seu cotidiano.

Os aspectos acima elucidados, ainda se interseccionam com um elemento pontual de relevância incontestável. Havia, nesse exato período, as eleições para governador, e o governante para dar uma resposta à comunidade que reivindicava a construção de uma nova escola, demandou da Secretaria de Estado de Educação do Distrito Federal (SEDF) que fizesse uma consulta pública à comunidade do Paranoá para discutirem a possibilidade da construção de uma futura escola. Um dos pais de aluno, em uma reunião, informou conhecer o dono do prédio comercial da Rua Transversal do Paranoá e mencionou que o prédio, onde funcionava a escola particular Barão do Rio Branco, dentro em breve, deveria ficar vago.

Toda esse preâmbulo elucida a situação de ocupação do atual prédio para que se reflita acerca da diversidade de elementos que compõem e dialogam com a comunidade escolar.

O CEF 05 surge, então,em um contexto em que se poderia alocar alunos com grandes problemas em um prédio comercial em ótima localização. Assim, aproveitando o ensejo, os gestores das escolas de ensino fundamental anos finais, os Centros de Ensino Fundamental $(\mathrm{CEF}) \mathrm{s}$, transferiram todos os alunos "problemáticos" para o estabelecimento disponibilizado. No entanto, não se atentara, que a estrutura física do prédio, quando era escola particular, possuía uma manutenção mais constante e o contexto socioeconômico e comunitário da escola equalizavam a exiguidade espacial do ambiente. Ou seja, os alunos apresentavam perfil distinto, o que refletia no seu comportamento e atitudes. Quando o CEF 05 foi inaugurado, no ano de 2015, cenas de caos se sucederam: consumo de drogas nos corredores; tráfico; intimidações e brigas de gangues na porta da escola.

Apesar de sua situação de violência, a escola possui uma excelente localização geográfica na cidade. A rua transversal culmina no Posto de Saúde e é perpendicular à Avenida Principal. A região vizinha possui restaurantes, farmácia, lanchonete, sacolão, mini mercados, padaria, bares, distribuidoras de bebida, lava-jato entre outros estabelecimentos comerciais. A rua transversal ainda encontra-se perto do Paranoá Park, projeto habitacional construído pelo programa do governo Minha Casa, Minha Vida. Contudo, a escola também se situa entre ruas que, segundo o relato dos alunos, abrigam bocas de fumo. 
A realidade escolar, em um primeiro momento, se apresentava extremamente complexa e o desafio pedagógico imenso. Em termos práticos, para os pais e os alunos a questão comodidade de deslocamento foi, sem dúvida, um fator importante para a aceitação do projeto, mas o que se atestou, na prática, era que a estrutura física não comportaria, adequadamente, a demanda de matrícula de um grande número de alunos em defasagem e com problemas de comportamento. Este fato gerou um ano de intenso desgaste em que tive que solicitar duas licenças médicas por estafa emocional e física.

No decorrer do ano, com as melhorias físicas e pedagógicas, bem como, com a pulverização e a troca de alunos com outras escolas, houve uma significativa melhora. As aulas de música desta pesquisa foram elaboradas neste período narrado e competia, no meu cotidiano escolar, com 22 diários a serem preenchidos e aulas noturnas no curso de mestrado. Assim, a escola é, hoje, apesar de todos seus problemas, composta, em sua maioria, por alunos e funcionários que tentam ao máximo, em sua maioria, dentro das inúmeras restrições observadas, desenvolver um ensino de qualidade.

\subsection{DO CONTINGENTE DOCENTE E DISCENTE DO CEF 05 DO PARANOÁ}

A Escola CEF 5 do Paranoá, aberta no contexto geográfico e socioeconômico apresentado anteriormente, recebeu alunos do Ensino Fundamental, anos finais, com idades entre 14 e 17 anos. Na primeira fase de matrícula foi previsto o atendimento a 850 alunos em defasagem escolar ou repetentes.

Segundo a nova versão do PPP da escola, elaborado no final do mês de junho do ano de 2016, O CEF 05 do Paranoá, a partir do ano de 2016, começou a disponibilizar turmas de primeiro ano do ensino médio. Em 2015, os alunos estavam dispostos em dois turnos: no matutino em 19 turmas, e 17 turmas no vespertino, totalizando 36 turmas e 693 alunos (BRASÍLIA, 2015).

Os alunos, inicialmente, apresentavam um comportamento ansioso, pois muitos deles eram advindos de uma condição de repetência sucessivas e de problemas disciplinares como consumo de drogas e depredação do patrimônio público. A tensão no ambiente escolar foi se agravando a ponto de dois funcionários pedirem transferência e, um coordenador e uma funcionária serem agredidos e ameaçados de morte. 
A direção, inicialmente designada pelo chefe da Gerência Regional de Educação do Paranoá, pediu demissão e, interinamente, foram designados diretores que permanecem no cargo até o final de 2015, e continuaram por 2016. Passado o primeiro ano de inúmeras agruras e turbulências, ambiente no qual, inclusive, esta pesquisa foi elaborada, inúmeras discussões e ações foram tomadas para que o ambiente escolar fosse aprimorado, dentro das possibilidades da SEDF e da escola. A direção tentou de várias formas, dentro das suas limitações, corrigir e solucionar as emergências que ocorriam. Nesse contexto, o PPP foi elaborado.

O novo PPP da escola ficou pronto logo após o término da coleta de dados desta dissertação, no entanto, ainda que puramente idealizado e em fase embrionária de sua aplicação na escola, a direção demonstra grande esforço e boa vontade no sentido de implementar as ações pedagógicas planejadas. Assim, no atual momento, de acordo com o PPP, a escola apresenta a seguinte organização: turmas de sextos, sétimos e oitavos anos, totalizando dezoito turmas com um total de 642 alunos (resultado preliminar segundo Censo Escolar 2016, BRASÍLIA, 2016), no turno matutino e no turno vespertino, oito turmas de nono ano e dez turmas do primeiro ano do ensino médio totalizando 305 alunos (resultado preliminar segundo Censo Escolar 2016, BRASÍLIA, 2016). Ao todo são 947 alunos, 254 alunos a mais do que o total de alunos matriculados em 2015 (693 alunos).

\subsection{DA ESTRUTURA FÍSICA}

A escola possui uma estrutura física ainda precária. Ela funciona em um prédio comercial de quatro andares e um subsolo, sendo que, no subsolo estão localizados a sala de vídeo, ambiente para atividades de Educação Física e duas salas de Artes. No térreo, se localizam a secretaria e a direção. No primeiro andar fica a sala de coordenação e a sala de professores, bem como, seis salas de aula. No segundo andar são disponibilizadas seis salas de aula (exemplo Apêndice A), uma sala de apoio para os professores e a sala de supervisão. No terceiro andar, mais seis salas de aula são utilizadas, o que soma o total de dezoito salas de aula e três salas de atividades pedagógicas específicas (Vídeo, Educação Física e Artes). No quarto andar, se localiza a quadra poliesportiva (ver fotos no Apêndice A).

Os corredores são estreitos e a ventilação dos andares é realizada, satisfatoriamente, por intermédio de ventiladores. Os acessos aos andares são realizados pelo uso de escadas. 
Todos os andares possuem dois banheiros com exceção do segundo que possui, além dos dois banheiros para alunos, dois banheiros para professores na sala de apoio. O prédio possui um elevador desativado, uma cantina e um pátio de circulação em frente à cantina.

Em um primeiro momento, tentou-se instalar uma sala de Artes, mas a Diretora em exercício decidiu extingui-la e esta passou a ser utilizada para altas habilidades em Artes cuja utilização é vedada para outros professores. Há uma sala que funcionava como depósito e foi improvisada como uma sala de Artes. A sala não é utilizada por mim, porque a ventilação é precária. A sala e o subsolo não possuem qualquer tipo de tratamento acústico, o que dificulta, também, ministrar aulas de música. Não obstante, o deslocamento com alunos pelos andares com corredores exíguos gera um desgaste e propicia incidentes disciplinares, uma vez que, em algumas ocasiões, quando tentei deslocar os alunos, alguns fugiram e se esconderam.

Desde a fundação da escola, com uma pequena reforma e readequação dos espaços, foram observadas melhorias na cantina, nos banheiros e no andar térreo. As salas possuem ventilação minimamente satisfatória e as salas de coordenação e de professores adquiriram arcondicionado. Os banheiros são limpos frequentemente. Um problema estrutural recorrente é o abastecimento de água, pois a caixa-d'água fica no andar da quadra esportiva e a bomba, frequentemente, estraga. A incidência desse problema tem, gradativamente, se tornado menos frequente.

As salas de aula têm janelas, mas elas são voltadas para a rua, são barulhentas e quentes, apesar de haver ventiladores nas salas, que nem sempre funcionam. Não há tratamento acústico nas salas.

Utilizo, na sala de aulas, instrumento, amplificador e caixa de som particulares, ou quando disponível, da escola. Na sala de aula, procuro observar como está o comportamento geral da turma no dia, se estão mais agitados, dispersos, concentrados, cansados. Os instrumentos de percussão e voz são utilizados para demonstrar exemplos com maior ênfase na experiência musical direta.

A duração de 45 minutos de aula exige uma dinâmica intensa. Procuro sempre diversificar bastante os momentos das aulas. Elas possuem um formato geral que consiste em recapitulação breve da aula anterior, introdução ao tema com exercício de alongamento, concentração e vocalize ou percussão corporal. A percussão pode ser palma, pisar no chão ou exemplos mais complexos executados por instrumento de percussão ou de corda. Utilizo ainda caixa de som para tocar trechos musicais e utilizo exemplos de faixas de musicas em 
mp3 ou $C D$, quando acompanho com diferentes instrumentos e destaco e reforço elementos que são necessários enfatizar. Nas aulas, há sempre um espaço para questionamentos e discussões. Nesses momentos, quando há dinâmicas de grupos, procuro pedir para organizarem as salas de aula em círculo. Os questionamentos e discussões em aula, inicialmente são tímidos, mas a medida em que o aluno entende a dinâmica entre a rotina dos exercícios e a liberdade do questionamento demonstra uma crescente confiança em si e no professor. Eles parecem conseguir compreender os diferentes momentos e a rotina não repetitiva parece causar o sentimento de familiaridade. Desse modo, os alunos parecem demonstrar, ainda que por vezes não participem, menos entediado e por vezes motivados. As aulas possuem, nesse formato geral, que pode ser alterado quando necessário, um planejamento formal com procedimentos e objetivos, no entanto, a dinâmica interativa na sala de aula pode sofrer interferência de inúmeros fatores como: alunos faltosos; queda da energia; falta de água e brigas que podem alterar o horário escolar.

Procuro realizar a chamada e anotar os procedimentos nos últimos três, ou quatro minutos e disponho de um ou dois minutos para guardar todos os objetos e sair correndo pelas escadas até a outra sala. Considerando que são seis aulas por dia.

\subsection{A PROPOSTA CURRICULAR DA ESCOLA,}

O Projeto Político Pedagógico da escola (PPP) foi, inicialmente, elaborado em um esforço conjunto da direção e do corpo docente. Em fase inicial, durante o ano de 2015, por causa das dificuldades vivenciadas pelo corpo docente na escola, situação apresentada anteriormente, foi elaborada uma primeira versão baseada em PPPs de outras escolas e em algumas inserções aprovadas pelo corpo docente e pela direção.

\subsubsection{Antecedentes: a Legislação Educacional do GDF: o Currículo em Movimento}

A legislação educacional do Distrito Federal, especificamente, a proposta curricular denominada Currículo em Movimento está em acordo com as Diretrizes Curriculares Nacionais da Educação Básica - DCNEB (BRASIL, 2013). Este documento coletivo foi elaborado com o objetivo de nortear, auxiliar e unificar as ações nacionais pela educação em cada estado preservando a sua autonomia. 
O presente trabalho não visa uma análise detalhada dos documentos legais, no entanto, destaco princípios e premissas que convergem para entender os fins, princípios e objetivos que orientam o Ensino Fundamental, séries iniciais no DF.

O dever do estado em promover educação de qualidade e inclusiva, encontra no ensino das Artes um importante mecanismo de promoção dessas premissas. Vale salientar que a música é uma linguagem que pode propiciar grande interação social, desenvolvimento cognitivo e consciência cidadã.A inclusão e desenvolvimento da educação musical no ensino básico aponta como as Artes em geral como conteúdo educacional e curricular para uma maior diversificação e criatividade do cotidiano escolar e como uma forma ativa e crítica de pensar e fazer no mundo. Podemos ver dentro da legislação as seguintes premissas que destacam o direito dos cidadãos ao EF e à formação integral, sendo ele um dever do estado.

Art. $3^{\circ} \mathrm{O}$ Ensino Fundamental se traduz como um direito público subjetivo de cada um e como dever do Estado e da família na sua oferta a todos.

Art. $4^{\circ}$ É dever do Estado garantir a oferta do Ensino Fundamental público, gratuito e de qualidade, sem requisito de seleção.

Parágrafo único. As escolas que ministram esse ensino deverão trabalhar considerando essa etapa da educação como aquela capaz de assegurar a cada um e a todos o acesso ao conhecimento e aos elementos da cultura imprescindíveis para o seu desenvolvimento pessoal e para a vida em sociedade, assim como os benefícios de uma formação comum, independentemente da grande diversidade da população escolar e das demandas sociais.

Art. $5^{\circ} \mathrm{O}$ direito à educação, entendido como um direito inalienável do ser humano, constitui o fundamento maior destas Diretrizes. A educação, ao proporcionar o desenvolvimento do potencial humano, permite o exercício dos direitos civis, políticos, sociais e do direito à diferença, sendo ela mesma também um direito social, e possibilita a

formação cidadã e o usufruto dos bens sociais e culturais.

$\S 1^{\circ} \mathrm{O}$ Ensino Fundamental deve comprometer-se com uma educação com qualidade social, igualmente entendida como direito humano.

$\S 2^{\circ}$ A educação de qualidade, como um direito fundamental, é, antes de tudo, relevante, pertinente e equitativa. (DCNEB, BRASIL, 2013).

Outra parte sensível a este trabalho se refere à questão do currículo para o Ensino Fundamental, anos finais. Relacionar deveres mais abrangentes do estado às situações mais específicas consiste em um exercício importante para qualidade e para o atendimento às idiossincrasias de uma determinada região. Sendo o país tão diverso, sua música comprova cabalmente isso, não podemos deixar de observar as características regionais e suas características específicas. Assim, a identidade do aluno e a construção do sujeito devem ser 
cuidadosamente observadas e encorajados, sob uma abordagem crítica na qual o aluno e o professor estejam sempre em construção.

A legislação destaca elementos importantes que orientam o currículo a integração entre saberes formais e informais, respeito às experiências dos alunos, integração no currículo da formação básica e formação diversificada, a liberdade da escola de selecionar no seu PPP conteúdos e atividades complementares:

Art. $9^{\circ} \mathrm{O}$ currículo do Ensino Fundamental é entendido, nesta Resolução, como constituído pelas experiências escolares que se desdobram em torno do conhecimento, permeadas pelas relações sociais, buscando articular vivências e saberes dos alunos com os conhecimentos historicamente acumulados e contribuindo para construir as identidades dos estudantes. Observar os fatores que contribuem e dificultam [...]

$\S 1^{\circ} \mathrm{O}$ foco nas experiências escolares significa que as orientações e as propostas curriculares que provêm das diversas instâncias só terão concretude por meio das ações educativas que envolvem os alunos.

$\S 2^{\circ}$ As experiências escolares abrangem todos os aspectos do ambiente escolar, aqueles que compõem a parte explícita do currículo, bem como os que também contribuem, de forma implícita, para a aquisição de conhecimentos socialmente relevantes. Valores, atitudes, sensibilidade e orientações de conduta são veiculados não só pelos conhecimentos, mas por meio de rotinas, rituais, normas de convívio social, festividades, pela distribuição do tempo e organização do espaço educativo, pelos materiais utilizados na aprendizagem e pelo recreio, enfim, pelas vivências proporcionadas pela escola.

$\S 3^{\circ}$ Os conhecimentos escolares são aqueles que as diferentes instâncias que produzem orientações sobre o currículo, as escolas e os professores selecionam e transformam a fim de que possam ser ensinados e aprendidos, ao mesmo tempo em que servem de elementos para a formação ética, estética e política do aluno. (Currículo em Movimento, Brasília, 2013).

Outro documento de particular relevância é a Base Nacional Comum Curricular (BNCC), em apreciação nos Estados em seminários planejados pelo Ministério da Educação e que terá, posteriormente, a discussão apreciada pelo Conselho Nacional de Educação (CNE). A BNCC constitui uma valiosa ação conjunta na tentativa de estabelecer critérios comuns às ações na educação. Ela encontra-se em sua segunda versão e está em fase de conclusão. Seu texto preconiza o ensino e a aprendizagem musical sob uma ótica abrangente, em que atribui relevância ao ensino de música.

Como complementaridade e obrigatoriedade de política educacional, o Distrito Federal, por intermédio da Secretaria de Estado de Educação (SEDF), formulou o currículo em movimento. $\mathrm{O}$ documento foi elaborado e preconiza elementos curriculares a serem 
trabalhados no Distrito Federal obedecendo ao que determina a legislação nacional para Educação Básica: Educação Infantil, Ensino Fundamental anos iniciais e anos finais e Ensino Médio.

O documento, no que se refere ao ensino de Artes nos anos finais do ensino fundamental, dentro de seus pressupostos teóricos, está muito bem alinhavado ao que preconiza o currículo nacional. Posso testemunhar a qualidade e o esforço do Currículo em Movimento por ter participado das discussões iniciais, audiências públicas e posterior elaboração do documento.

Em linhas gerais, o documento contempla a ideia de que o ensino de música não se restringe unicamente a execução de um instrumento musical ou execução de peças musicais, há, hoje, um entendimento sedimentado de que o ensino e aprendizagem musical é muito diversificada em suas abordagens e procedimentos. A percepção, o pensar sobre o fazer e a reflexão sobre a música, em seus múltiplos contextos, são uma preocupação teórica e prática do professor de música. O documento defende que para consolidar uma aprendizagem musical significativa é imprescindível compreender as funções que a música exerce na sociedade contemporânea e suas particularidades. Nele a música integra o componente curricular Artes que faz parte da área do conhecimento Linguagens. O currículo do Ensino Fundamental está dividido em anos iniciais e anos finais. Este apresenta quadros esquemáticos que abordam conteúdos e objetivos para a aula de música.

Dentre os pressupostos teóricos apresentados no Currículo em Movimento, especificamente, sobre a música no Ensino Fundamental anos finais e, mais objetivamente, no oitavo ano, as ações contempladas na presente pesquisa procuraram coerência e contemplaram, diretamente os pressupostos indicados. Assim, a presente monografia teve particular cuidado em contemplar não somente a diretrizes gerais, mais conceituais e abrangentes, como também, de maneira mais específica, os objetivos e conteúdos da proposta curricular do oitavo ano da disciplina de música. A abordagem pedagogicomusical das aulas procurou dialogar com o Currículo em Movimento, em que encontramos os seguintes objetivos: identificar manifestações musicais locais; vivenciar o fazer musical pela prática de conjunto, mais especificamente encontramos, discutir sobre o que é música; vivenciar e experienciar as diversas maneiras de fazer musical; criar cantar e executar melodias; desenvolver a análise auditiva para elementos básicos da música; analisar criticamente a música de mídia. Os objetivos citados encontram equivalência em conteúdos: paisagem 
sonora; o que é música; produção do som; música de mídia, jingles, novelas canções, propaganda novela filmes, elementos básicos da música, melodia, harmonia, ritmo, notação musical. (BRASÍLIA, Currículo em Movimento, 2013)

Portanto, a aplicação de questionários sobre preferências e práticas musicais corrobora para que se possa investigar o universo musical do aluno e interagir com seus conhecimentos prévios.

No entanto, os objetivos e conteúdos se referem à um cenário ideal, uma vez que, para que se possa executar as premissas propostas pelo Currículo em Movimento com qualidade, o ambiente escolar deve apresentar um panorama favorável tanto em infraestrutura quanto em recursos humanos que corroboram para o ensino de música. Situação diametralmente oposta à cultura de improviso e de precariedade dispensada à Educação Musical Escolar, bem como ao reconhecimento do professor de música como um especialista necessário e relevante para a formação cidadã e da sociedade.

\subsubsection{A música na proposta curricular da escola}

O ensino de Arte, especificamente, da Música na escola não é uma proposta objetiva e específica no PPP da escola. O documento apenas menciona que é objetivo da escola promover "atividades culturais" que, entre outras, podem ser musicais.

O corpo docente, bem como, a direção alegam que a escola tem maiores preocupações, uma vez que ela possui menos de um ano e sua estrutura física ainda é básica. Não obstante, o obstáculo mais relevante para implementar a música no documento parece residir na cultura escolar. As escolas não têm por hábito ter um profissional do ensino da Arte especializado em música. Durante o desenvolvimento desta pesquisa, houve um incômodo estranhamento por parte dos colegas e da direção. Fui questionado, por exemplo, pelo motivo de estar levando instrumentos musicais para a sala de aula.

$\mathrm{Na}$ cultura escolar local, os projetos relacionados à música sempre são entendidos e aceitos como projetos extracurriculares ou interventivos. Há uma cultura pedagógica, com vício de origem, que se apoia em jargões educacionais, que associam o nome oficina e contra turno aos projetos artísticos que parecem se justificar sobre si mesmos. Assim, a escola parece acolher, prontamente, um membro da comunidade sem formação específica em música ou em pedagogia musical, devido, principalmente, às questões políticas e administrativas. Soma-se a 
este fato, atualmente, a ausência de pessoal de apoio nas escolas e a contratação de voluntários e colaboradores como exemplo, o número crescente de jovens educadores nas escolas, monitores, que reproduzem modelos de ensino e aprendizagem, geralmente de maneira pouco reflexiva, ou exercem um papel de observadores e contentores do fluxo de alunos nos corredores. Assim, até o momento da coleta de dados e desenvolvimento desta pesquisa, o PPP se encontrava em formulação e, portanto, as críticas e as observações aqui apresentadas são parciais, na medida em que o documento definitivo não estava concluído.

Um fato importante é a mudança curricular do sistema seriado e bimestral para o sistemas de ciclos. Essa alteração implicou o planejamento e os reagrupamentos das turmas. Tal iniciativa parece ser interessante porém seus efeitos só poderão ser observados futuramente. Vale ressaltar que em nenhum momento me foi perguntado ou consultado sobre o ensino de Artes, especificamente, o conteúdo música na proposta curricularda escola.

Não participei, portanto, das discussões do PPP, uma vez que estas eram feitas eventualmente, quando feitas, em horário de coordenação. Esses horários coincidiram com os horários do mestrado e das orientações.

O que claramente se identifica na escola é uma dificuldade considerável em se entender a função da música e do professor de música na organização do trabalho escolar, justamente por não haver uma cultura de educação musical reconhecida pela administração educacional e exercida por profissionais com formação específica,

Esse contexto possibilita uma reflexão mais concisa e aprofundada sobre os resultados, uma vez que influi diretamente no trabalho. Assim, a reflexão sobre os resultados está impregnada de fatores diversos que são, por vezes, objetivamente aferidos e por outras, subjetivamente sentidos. 


\section{REFLEXÃO SOBRE OS RESULTADOS}

"Por que o estudo hoje em dia, determina o que a pessoa vai ser (Q1)"

A epígrafe acima retrata o valor dado à educação pelo(a) jovem respondente do questionário 1. Na proposta investigativa desta monografia, a aplicação dos questionários foi relevante para embasamento e complementação das reflexões geradas a partir da execução das aulas de música objeto deste estudo. Os resultados foram bem interessantes e corroboraram com as ponderações e problematizações iniciais, no entanto, uma análise mais aprofundada proporcionou novos dados e reflexões. As ações pedagógicas efetuadas e a pesquisa realizada reuniram informação relevantes para refletir sobre os resultados desta dissertação e sobre as aulas de músicas no ambiente escolar. Neste capítulo, apresento os resultados dos questionários e reflito sobre as atividades da proposta musical delineada no objetivo deste trabalho: refletir sobre as possibilidades e os desafios de aulas de música desenvolvidas para conscientizar os alunos do $8^{\circ}$ ano do CEF 05 do Paranoá, sobre as suas vivências musicais, não as negando, mas expandindo seu referencial de repertório.

Para que uma análise criteriosa da turma pudesse ser efetuada, observou-se no total dos dados fornecidos pelos questionários, a análise e interpretação de categorias a serem apresentadas neste tópico.Tal categorização é proveniente das respostas dos próprios alunos.

Os resultados observados na proposta pedagógica também são considerados. Eles demonstram que os(as) alunos(as) estão sob forte influência da mídia, o que implica refletir sobre ações didáticas que poderiam aproximar o conhecimento teórico do conhecimento prático.

Cabe ainda questionar quais são os motivos que separam o discurso do aluno do seu comportamento e atitudes. Me parece que uma ação educativa musical deve apontar para atividades que proporcionem ao aluno a liberdade de criação e expressão, uma vez que, na maioria das respostas à questão para que serve a música, a palavra "expressar" foi amplamente recorrente.

$\mathrm{Na}$ seção a seguir, discutimos os resultados encontrados de acordo com as categorias que emergiram dos questionários das aulas de música realizadas na turma do $8^{\circ}$ ano $\mathrm{A}$. 
Assim, o diálogo entre a dimensão musical e a social estão sempre presentes (DYNDAHL; KARLSEN; WRIGHT, 2014) e para isso o entendimento do perfil socioeconômico desses alunos é importante.

\subsection{OS ALUNOS: QUEM SÃO OS JOVENS DO OITAVO ANO ‘A’ E SUA RELAÇÃO COM A MÚSICA}

É importante entender quem são os(as) alunos(as) e como eles se vêem e compreendem o mundo à sua volta. A fase que os(as) alunos(as) se encontram é um momento muito rico e intenso e obter dados consistentes sobre esses indivíduos é muito relevante para que se possa planejar e executar ações educativas que tenham sinergia com toda a sua potencialidade.

Encontramos importante reflexão na seguinte citação de Dayrell (2011) sobre o jovem de 13 a 16 anos:

É o momento privilegiado de se descobrirem como indivíduos e sujeitos buscando um sentido para a existência individual. É um momento próprio de experimentações, de descoberta e teste das próprias potencialidades, de demandas de autonomia que se efetivam no exercício de escolhas. (DAYRELL, 2007 apud DAYRELL; NOGUEIRA; MIRANDA, 2011, p.28).

Inicialmente, para traçar o perfil dos jovens do $8^{\mathrm{a}}$ ano $\mathrm{A}$, suas preferências e práticas musicais, faz-se necessário delimitar o conceito de jovem que este texto adota. Entendo o termo juventude a partir da perspectiva de Dayrell (2003) que define a palavra juventude como "uma condição social e um tipo de representação" que está sujeita às mudanças físicas, temporais, psicológicas e sociais. Em suas palavras:

[...] a juventude é, ao mesmo tempo, uma condição social e um tipo de representação. Se há um caráter universal dado pelas transformações do indivíduo numa determinada faixa etária, nas quais completa o seu desenvolvimento físico e enfrenta mudanças psicológicas, é muito variada a forma como cada sociedade, em um tempo histórico determinado, e, no seu interior, cada grupo social vão lidar com esse momento e representá-lo (DAYRELL, 2003, p.42)

Sob esta abordagem, Dayrell (apud DAYRELL; NOGUEIRA; MIRANDA, 2011) adota a ideia de "condição juvenil", que apresenta duas dimensões: historicogeracional e situacional, esta relativa ao "modo como tal condição é vivida a partir dos diversos recortes 
referidos às diferenças sociais - classe, gênero, etnia, etc.” (DAYRELL; NOGUEIRA; MIRANDA, 2011, p. 16)

Reconhecer a condição juvenil desses estudantes significa reconhecer o jovem como sujeito social e o seu direito de ser jovem. Assim, as falas dos jovens do $8^{\circ}$ ano A são dotadas de significado e de visão de mundo que deve ser ouvida e valorizada.

É importante, ainda, considerar que são várias juventudes implícitas no ser jovem: ter 12 anos é diferente de ter 16 ou 22 anos. Essa diferença é reforçada pelas experiências vividas, ou seja, as histórias pessoais são distintas: jovens de zona rural se distinguem dos jovens de zona urbana ou de classes sociais e de escolaridade distintas (DAYRELL; NOGUEIRA; MIRANDA, 2011, p. 17). Quando discutem a juventude e o ser jovem, Dayrell, Nogueira e Miranda (2011) o fazem a partir da perspectiva escolar e, nesse contexto, chamam atenção para os rótulos associados a esse jovem na/fora da idade escolar: o jovem como promessa e o jovem como problema. Essa ambiguidade é discutida no capítulo anterior, quando apresento o contexto escolar desta pesquisa, e também, de forma subliminar, na apresentação dos resultados, uma vez que o $8^{\circ}$ ano $\mathrm{A}$ é constituído por jovens na/fora da idade escolar e por jovens rotulados de problemáticos, embora representem a promessa de futuro da sociedade.

Portanto, os alunos do oitavo ano A ( $\left.8^{\mathrm{a}} \mathrm{A}\right)$, respondentes do questionário $(\mathrm{N}=18)$, são jovens adolescentes, na faixa etária de 13 a 16 anos, sendo 9 alunos do sexo masculino (50\%) e 9 alunas do sexo feminino (50\%) conforme a tabela 1. Entre eles, 13 alunos (18 respondentes) informaram a faixa etária, sendo 7 do sexo masculino $(n=7)$ e 6 do sexo feminino $(\mathrm{n}=6)$. Na tabela 1 , a percentagem é calculada por amostragem de sexo. Os resultados apontam que 2 alunos $(22,22 \%)$ e 3 alunas $(33,33)$ têm 13 anos de idade e 1 aluno $(11,11 \%)$ tem 16 anos enquanto não há alunas nessa faixa etária. Na idade de 14 anos não há nenhum aluno, mas 1 aluna respondente $(11,11 \%)$. A maior quantidade de alunos do sexo masculino está na faixa etária de 15 anos, ao todo $4(44,445)$, enquanto que, do sexo feminino, são 2 alunas nessa faixa etária $(22,22 \%)$. A idade média da turma $(\mathrm{N}=13)$ é de 14,23 anos, sendo a faixa etária média masculina de 14,57 anos e a feminina de 13,83 anos. A mediana, ou valor do meio das faixas etárias da turma corresponde à 15 anos, mas a mediana por amostragem de sexo é 15 anos para o sexo masculino e 13 e meio para o sexo feminino. Tanto a média quanto a mediana apontam para a tendência dos jovens do sexo masculino estarem fora da faixa etária escolar. Essa tendência é confirmada pelo cálculo da moda ou 
valor etário que ocorre com maior frequência. Para a turma como um todo, a moda é 15 anos (6 ocorrências); para os alunos a moda é também 15 anos, mas para as alunas a moda é de 13 anos (3 ocorrências).

Tabela 1 - Relação entre sexo e faixa etária

\begin{tabular}{cccc}
\hline SEXO & $\begin{array}{c}\text { IDADE / ANOS* } \\
(\mathrm{N}=13)\end{array}$ & $\begin{array}{c}\text { QTDE ALUNOS } \\
(\mathrm{AS})\end{array}$ & $\%$ \\
\hline \hline Masculino $(50 \%-\mathrm{N}=9)$ & 13 & 2 & $28,57(\mathrm{n}=7)$ \\
& 14 & 0 & 0 \\
Feminino $(50 \%-\mathrm{N}=9)$ & 15 & 4 & $57,14(\mathrm{n}=7)$ \\
& 16 & 1 & $14,29(\mathrm{n}=7)$ \\
& 13 & 3 & $50,00(\mathrm{n}=6)$ \\
& 14 & 1 & $16,67(\mathrm{n}=6)$ \\
& 15 & 2 & $33,33(\mathrm{n}=6)$ \\
& 16 & 0 & 0 \\
\hline \hline
\end{tabular}

*Dois (2) alunos e três (3) alunas não responderam a idade.A população para faixa etária é de 13 alunos $-\mathrm{N}=13$, sete alunos $(\mathrm{n}=7)$ e seis alunas $(\mathrm{n}=6)$.

Fonte: Dados de Questionário Preferências Musicais

Apesar da diferença de faixa etária entre os alunos, há entre eles uma atmosfera de empatia.Os alunos e as alunas são vivazes e, algumas vezes, barulhentos.

Com relação à raça, eles se percebem brancos $(36,4 \%, 4$ alunos de $\mathrm{N}=11$ respondentes); pardos $(36,4 \%, 4$ alunos de $\mathrm{N}=11$ respondentes $)$, pretos $(18,2 \%-2$ alunos de $\mathrm{N}=11$ respondentes) e amarelo $(9,1 \%$ de 1 aluno de $\mathrm{N}=11$ respondentes). Dentre os que se definem como branco, $50 \%$ (2) são do sexo masculino e 50\% (2) são do sexo feminino. Entre os pardos, os homens são a maioria (27,3\%, 3 alunos), assim como entre os pretos $(18,2 \%, 2$ alunos). $\mathrm{O}$ respondente que se identificou como amarelo é do sexo feminino. Esses números comprovam a proporção quantitativa entre brancos, pardos, negros e amarelos no país. Segundo dados do Censo Demográfico 2010 coletados pelo Instituto Brasileiro de Geografia e Estatística (IBGE), 47,8\% da população se declarou branca, 50,7\% negra, 1\% amarela e 0,5\% indígena (BRASIL, 2015). Segundo o mesmo instituto, os negros são aqueles que se consideram pretos e pardos. Nessa classificação, o $8^{\circ}$ ano A tem 54,6\% de alunos negros, 36,4 $\%$ de brancos e $9,1 \%$ de amarelos. 
Tabela 2 - Raça e sexo

\begin{tabular}{ccccccc}
\hline & Raça & & \multicolumn{2}{c}{ Masculino } & \multicolumn{2}{c}{ Feminino } \\
\hline \hline Branco & 4 & $36,40 \%$ & 2 & $18,20 \%$ & 2 & $18,20 \%$ \\
Preto & 2 & $18,20 \%$ & 2 & $18,20 \%$ & - & - \\
Pardo & 4 & $36,40 \%$ & 3 & $27,31 \%$ & 1 & $9 \%$ \\
Amarelo & 1 & $9 \%$ & - & - & 1 & $9 \%$ \\
Indígena & 0 & $0 \%$ & - & - & - & - \\
\hline \hline TOTAL & 11 & $100 \%$ & 7 & & 4 & \\
\hline
\end{tabular}

Fonte: Dados Questionário Socioeconômico

De modo geral, os(as) alunos(as) não trabalham. Nenhum dos alunos que respondeu o questionário $(100 \%, \mathrm{~N}=11)$ trabalha, como também todos alegam não ter filho.

Com relação a naturalidade, 64\% (7 alunos de N=11) nasceram no Distrito Federal (Brasília e Planaltina), 18\% (2) no Pará, 9\% (1) no Maranhão e 9\% (1) no Piauí.

A maioria dos respondentes reside no Paranoá ( $75 \%$ - 9 alunos de N=12), 17\% (2) no Itapoã e 8\% (1) em Sobradinho dos Melos. Há uma certa predileção pela proximidade da escola com a própria casa. O baixo tempo de deslocamento fazcom que o(a) aluno(a) tenha uma identificação não somente com a escola em si, mas com os membros da comunidade escolar que por muitas vezes são seus vizinhos. A maioria dos(as) alunos(as) mora no próprio bairro da escola,o que justifica o tempo de 5 min a 10 min que $46 \%$ ( 3 alunos e 3 alunas) dos respondentes alega levar para chegar à escola. $\mathrm{O}$ aluno que mora mais distante ( $8 \%, 1$ aluno) leva $40 \mathrm{~min}$ se locomovendo. Dois respondentes ( 1 aluno e 1 aluna) levam menos de 5 min para chegar à escola, mas os(as) alunos(as) acordam em médiaàs $6 \mathrm{~h}$ e 10 minutos.

Tabela 3 - Tempo de locomoção e horário que acorda

\begin{tabular}{cccc}
\hline $\begin{array}{c}\text { Tempo para } \\
\text { chegar à } \\
\text { escola }\end{array}$ & $\begin{array}{c}\text { Qtde } \\
\text { alunos(as) }\end{array}$ & $\%$ & $\begin{array}{c}\text { Horário que } \\
\text { acorda }\end{array}$ \\
\hline \hline menos de 5 min & 2 & $15 \%$ & $6 \mathrm{~h} / 6 \mathrm{~h} 40$ \\
5 a 10 & 6 & $46 \%$ & $6 \mathrm{~h} / 6 \mathrm{~h} 30$ \\
10 a 15 & 0 & - & $6 \mathrm{~h} 20$ \\
15 a 20 & 2 & $15 \%$ & $6 \mathrm{~h} 20$ \\
20 a 30 & 1 & $8 \%$ & $6 \mathrm{~h}$ \\
40 & 1 & $8 \%$ & $6 \mathrm{~h}$ \\
não sabe & 1 & $8 \%$ & $5 \mathrm{~h} 30$ \\
\hline \hline TOTAL & $\mathbf{1 3}$ & & \\
\hline \hline
\end{tabular}

Fonte: Dados Questionário Socioeconômico 
Apesar de alegarem morar perto da escolar, os(as) estudantes são, em sua maioria, bastante faltosos. A assiduidade é o principal problema na sala de aula que compromete o rendimento escolar.Contudo, com relação às aulas de música, a turma apresentou rendimento satisfatório no primeiro bimestre de 2016 e os alunos e as alunas participaram de maneira cooperativa nas atividades ao longo do projeto.

Os(as) alunos(as) consideram o estudo muito importante, 100\% ( $\mathrm{N}=12$ respondentes) das respostas à pergunta: Você acha que o estudo vai fazer alguma diferença na sua vida?

Tabela 4 - Importância do estudo na vida

\begin{tabular}{ccc}
\hline \multicolumn{3}{c}{ Importância do estudo na vida (N=12) } \\
\hline Nada & 0 & $0 \%$ \\
Pouco & 0 & $0 \%$ \\
importante & 0 & $0 \%$ \\
Mais ou menos & 0 & $0 \%$ \\
Importante & 12 & $100 \%$ \\
Muito & 12 \\
importante &
\end{tabular}

Fonte: Dados Questionário Socioeconômico

Os alunos justificam sua resposta com base em crenças e valores do senso comum que afirmam que o estudo é importante porque: faz a pessoa ( 2 incidências); é base para tudo (3 incidências); é futuro, sustento e conquistas ( 2 incidências); é futuro e realização (3 incidências); possibilita estabilidade (1 incidência); possibilita emprego, estabilidade e sustento (1 incidência). As falas dos(as) estudantes são representativas:

Por que o estudo hoje em dia que determina o que a pessoa vai ser. (Q1). Os estudos são a base de tudo. (Q2).

Porque através dele eu vou poder garantir futuro, o meu o meu sustento e também fazer minhas conquistas. (Q5).

Porque sem o estudo não vamos chegar a lugar nenhum.(Q10).

Aúnica coisa que preciso. (Q15).

Em seu discurso, os(as) alunos(as) apresentam uma consciência da relevância da educação para a formação do indivíduo, a ponto da maioria desejar cursar o ensino superior $(100 \%, N=13)$, pois acreditam que a escolarização gerará suporte socioeconômico.

Dayrell, Nogueira e Miranda, (2011) apontam a importância da escola para os jovens:

A escola é muito valorizada pelos jovens no que ela aporta de convivência e preparação para o futuro, mesmo que sem muito sentido prático para as 
demandas de inserção no trabalho. Lá estão os amigos e conhecidos da vizinhança, lá ressoam os acontecimentos presenciados na cidade e no entorno, lá é possível se reconhecer como participante de uma instituição aberta para o seu cotidiano. (DAYRELL; NOGUEIRA; MIRANDA, 2011, p.46).

Eles(as) entendem o papel da escola para a comunidade e da relevância da disciplina e do respeito para o bom convívio na comunidade escolar. Contudo, também respondem nesse sentido por entenderem que é a resposta certa, a resposta que se espera como "politicamente correta”. Nas falas dos(as) alunos(as) percebe-se a tendência de se repetir o que se ouve. Ao reproduzir o próprio discurso da escola, os(as) alunos(as) demonstram acreditar na promessa de sucesso e aparentam responder de acordo com o que se espera deles.

O interessante é observar que os alunos consideram o estudo como algo que vai transformá-los em alguém. Isto demonstra um dado preocupante, o aluno não se vê como sujeito histórico, ele acredita que a educação o transformará em alguém apto por sua capacidade de servir a um emprego, ou seja a ideia de ser, de identidade, parece está enevoada pela ideia de função econômica, ser alguém aponta como alguém que tem dinheiro. A relação do estudo com a ascensão econômica aparece nas falas desses(as) jovens:

Por que sem os estudos não sou boa em nada. (Q14).

Porque sem os estudos eu não vou chegar a lugar nenhum (Q10).

No entanto, um fator subjetivo é importante de ser mencionado: há uma certa distância entre o discurso apresentado nos questionários e o comportamento observado em sala de aula. Apesar de reconhecerem a relevância da educação e desejarem cursar o ensino superior, em sala de aula, os alunos demonstram indisciplina e inconsistência e falta de motivação para perseverar nos estudos. Tal elemento não surpreende, uma vez que se o(a) aluno(a) julga que ele(a) precisa do estudo para se tornar alguém subjetivamente. Contudo, parece que a escola, enquanto proporciona essa possibilidade, o(a) constrange ao mesmo tempo, pois evidencia que ele(a) não é ninguém. Nesse sentido, ações musicais criativas de composição que sugerem e propiciam empoderamento podem trazer a devida autoestima e autonomia (FREIRE 1986), e auxiliar na construção da conscientização desse(a) aluno(a) (FREIRE 1979).

As respostas ainda sugerem a importância de atividades e de conteúdos para o ensino de música no currículo escolar. Os(As) alunos(as) indicam que atividades como o esporte e a música podem ser de melhoria para o ambiente escolar.Contudo, eles(as) parecem apresentar 
uma relação ambígua com a escola. Pretendem cursar anos de estudo, porém oferecem grande resistência à formalização do conhecimento.

De modo geral, a turma de $8^{\circ}$ ano A não apresentou problemas significativos de disciplina, salvo em alguns episódios. Quanto ao seu comportamento, atitudes e modos de ser, os alunos se percebem como alunos responsáveis pelo sucesso ou insucesso escolar.Mais uma vez, eles parecem responderem função do que julgam ser o que se espera como resposta correta.

No questionário socioeconômico, ao perguntar de que maneira os(as) alunos(as) podem contribuir para a convivência escolar, eles são unânimes em reconhecer o valor da disciplina:

Posso contribuir me comportando, respeitando os professores e fazer todas as atividades. (Q4).

Eles(as) associam a escola à ascensão social:

Porque através dele eu vou poder garantir futuro, o meu o meu sustento e também fazer minhas conquistas.(Q3)

Um ponto a destacar com relação à disciplina e participação nas aulas é a estreita relação com o celular, a ponto de não conseguirem ficar muitos minutos sem utilizá-lo. Não é raro, durante a aula, os alunos colocarem quase que de maneira mecânica o fone de ouvido. $\mathrm{O}$ celular para os(as) alunos(as) também está relacionado à ideia de lazer, ainda faz parte da indumentária do jovem e está muito relacionado à identidade do(a) aluno(a). $\mathrm{O}$ fato de não trabalharem parece também influir no comportamento desses alunos. Ouvir música com os amigos possui baixo custo ( DAYRELL; NOGUEIRA; MIRANDA, 2011).

O uso do celular como forma de "evadir" da sala de aula pode ser observado, em um dos momentos, quando me dirigi à um aluno para solicitar que retirasse o fone de ouvido porque iria tocar um exemplo de uma célula rítmica contida em um trecho da música que eles haviam pedido: de MC João. Este episódio, além de gerar um impasse de autoridade, serve também para ilustrar como é possível diagnosticar a vivência musical que os alunos têm. A música Baile de Favela foi citada por 10 alunos(as) (52,73\%, N=19; Apêndice E) como reposta ao questionário diagnóstico referente às músicas que faziam sucesso. Essa mesma música foi indicada como uma de suas preferidas por 2 alunos(as) $(10,53 \%$ de $\mathrm{N}=19$, Apêndice E). 
Entretanto, os(as) alunos(as), de modo geral, sequer associam o ouvir música com o pensar, mais profundamente, sobre o que se ouve ou com a cultura e o conhecimento musical.

Obviamente as generalizações se apresentam muito perigosas, e o trabalho de tomar conhecimento do que os alunos entendem por música é muito importante, encontramos na fala do aluno um forte indício de conscientização acerca do fazer musical que parece apontar para a conscientização:

A música decifra a realidade de muitos e também ensina. (Q7)

Por outro lado, o comportamento, praticamente autômato, de colocar o fone de ouvido ou de ficar obcecado pelo celular em situações de sala de aula ou em momentos sociais demonstra a falta de interesse dos jovens na escola e a urgência em desenvolver ferramentas reflexivas que estimulem pensar sobre essas atitudes. O desenvolvimento do senso crítico pode mudar a escuta e a consciência de si. De modo geral, utilizar o celular ou colocar o fone de ouvido pode indicar uma fuga da realidade, o(a) aluno(a), automaticamente, troca a "chatice" da sala de aula pelo que ele(a) gosta e lhe dá prazer, ao mesmo tempo em que, se mostra rebelde e insatisfeito. Nessas circunstâncias, a aula de música pode ser uma ferramente formativa, pode ensinar, como afirma o(a) aluno(a) do questionário 7. Essa situação de "fuga" me instigou e gerou mudanças na minha forma de lecionar. Existem formas de despertar o interesse dos(as) alunos(as) que não seja pelo conforto, mas pela inquietação.

A partir dessa situação e reflexão, decidi, então, que deveria elaborar ações que contemplassem o celular como ferramenta musical.Os(As) alunos(as) do oitavo ano, não raro apresentam uma postura de desinteresse e cansaço: eles(as) gostam da aula de música, mas apresentam muita resistência aos exercícios que demandem maior teor de concentração ou esforço mental. Por outro lado, os(as) alunos(as) reagem muito bem à exercícios de percussão corporal ou ainda à exercícios de análise musical mais rudimentares. Eles(as) estão muito interessados em questões concernentes à juventude, que é namorar sair e aprender a relacionar-se.

Compreender os(as) alunos(as) em sua dimensão juvenil é um exercício muito importante. Esta percepção é relevante, uma vez que, para ministrar aulas de música, em um contexto em que não há uma cultura de educação formal de música, o professor precisa estar muito apropriado do contexto geral e específico de cada turma para interagir. O que torna a 
tarefa desafiadora, uma vez que, uma turma como a do oitavo ano é uma das quinze turmas que um professor de Artes tem.

No entanto, a observação subjetiva não é suficiente. É muito importante que o professor tenha um constante exercício de sensibilidade aliada a um método que possibilite a reunião de dados objetivos sobre a turma. Para isso, a aplicação do questionário sócio econômico foi relevante. Esse apontou dados específicos sobre a localização, moradia, referencial regional, acesso a internet, configuração familiar e expectativas concernentes à vida escolar e à sociedade, bem como, à própria percepção do seu mundo social enquanto estudante e membro da comunidade escolar como apresentado anteriormente.

Quanto à internet, todos(as) os(as) alunos(as) informam que acessam diariamente a internet $(92,30 \%$ de $\mathrm{N}=13)$, o que demonstra que eles possuem acesso a rede de dados, e que têm certa familiaridade com a internet. Estas informações auxiliam o professor no diálogo e no direcionamento da dinâmica de ensino e aprendizagem dentro e fora da sala de aula. Dados objetivos e quantificados possibilitam o diagnóstico e as estratégias de ensino e aprendizagem nos quais a fala e as preferências dos alunos sejam percebidas e respeitadas. O questionário, ainda ao apresentar dados objetivos quantificados, pode fornecer dados para toda escola, e embasar procedimentos pedagógicos no sentido de aprimorar o ensino e aprendizagem.Não obstante, embasa a postura e o trabalho do professor frente à comunidade escolar.

O que se pode constatar é que, de maneira geral, todos os alunos tem um vínculo cotidiano com a música: 1) eles ouvem música e durante muitas horas por dia; 2) eles conhecem as músicas que estão na moda por intermédio do uso de gadgets, PCs e aparelhos eletrônicos. A música faz parte do cotidiano desses adolescentes como respondem os(as) alunos(as) quando questionado sobre o que é música para ele e quando ouvem música:

A música é uma coisa que não sabemos, mas que gostamos, que é composta por artista, mas que expressa alguma coisa. (Q 3)

Tudo aquilo que se houve que é legal. (Q6)

Tomar conta de meus irmãos mais novos. Fazer tarefas domésticas. Estudar. Assistir aula. Jogar no computador ou no celular. Navegar na internet e interagir nas redes sociais. Conversar com amigos no celular. Tomar banho e me arrumar.(Q 2).

Os(As) alunos(as) ouvem música o tempo todo: em casa, na rua e na escola. Quando ouvem música realizam, ao mesmo tempo, tarefas escolares, domésticas e atividades de lazer, 
ouvindo música. Vários(as) alunos(as) ouvem música enquanto tomam conta dos irmãos mais novos. Eles(as) ouvem música por meio de rádio, televisão e internet.

Quanto às práticas musicais, apenas dois alunos cantam informalmente e um toca com uma banda. Três alunos já tiveram aula de música fora da escola. Nenhum dos alunos afirmou realizar composições musicais. Os(As) alunos(as) ainda disseram que o principal material que prestam atenção em uma composição musical é a "batida" ou a "letra". Se entendem que a educação serve para torna-los "alguém", a aula de música pode servir para torna-los conscientes de quem são e o valor que isso tem para a transformação do mundo, não em um momento futuro, mas aqui e agora.

A pesquisa indicou que os(as) alunos(as) também gostam muito de ouvir os mesmos estilos, não obstante eles(as) demonstraram preferências distintas . Na tabela 5, os(as) alunos(as) respondem sobre as músicas “da moda" e sobre as "músicas que gostam”. Gostaria de saber se havia uma relação entre a música da moda e o gosto pessoal.

Tabela 5 - Músicas da Moda e que os alunos gostam de ouvir, incidências $(N=19)$ INCIDÊNCIA DAS MÚSICAS INDICADAS QUESTÕES ABERTAS (N=19)

\begin{tabular}{|c|c|c|c|c|c|}
\hline Músicas 'Da Moda' & Q. & $\%$ & Músicas que gostam & $\mathbf{Q}$ & $\%$ \\
\hline Metralhadora & 16 & $84,21 \%$ & Metralhadora & 5 & $26,32 \%$ \\
\hline $\begin{array}{l}\text { Tá tranquilo, tá } \\
\text { favorável }\end{array}$ & 13 & $68,42 \%$ & Tá tranquilo, tá favorável & 4 & $21,05 \%$ \\
\hline Baile de Favela & 10 & $52,73 \%$ & Bar das Coleguinhas & 3 & $15,79 \%$ \\
\hline Bar das Coleguinhas & 3 & $15,79 \%$ & Baile da Favela; Funks & 2 & $10,53 \%$ \\
\hline $\begin{array}{l}\text { Paredão; Eu sosseguei e } \\
\text { Sorry }\end{array}$ & 2 & $10,53 \%$ & Não gosta de ouvir música & 1 & $5,26 \%$ \\
\hline $\begin{array}{l}\text { De longe; Meu violão e } \\
\text { o nosso cachorro; } \\
\text { Porque homem não } \\
\text { chora; Chefe é chefe, né } \\
\text { pai?; Nada bom; Sem } \\
\text { graça; Hungria e Funks } \\
\text { (estilo) }\end{array}$ & 1 & $5,26 \%$ & $\begin{array}{l}\text { Beautifull, When she's gone. Envolvidão. } \\
\text { Bob voltou. Viva seu melhor. Mc Krum } \\
\text { Vera Cruz. Raridade. Sempre vida loka, } \\
\text { depois da zero, Jesus chorou. O escudo. } \\
\text { Advogado fiel. O maior troféu. Eu te amo } \\
\text { sexta-feira. Se cuida. Love Yourself. Nada } \\
\text { bom, Sorry, Sem graça; Children. Elas } \\
\text { gostam Assim. What do YouMean?; } \\
\text { Hungria. Caia fogo. Mina de virtude. Som } \\
\text { da liberdade; Magic Hud; Realidade cruel. } \\
\text { Sonho; Te amo; Dracma perdida. Ao único. } \\
\text { Aos olhos do pai. Rap e Sertanejo (estilos) }\end{array}$ & 1 & $5,26 \%$ \\
\hline
\end{tabular}

Fonte: Dados dos questionários de Preferências Musicais, questões abertas

Dentre as músicas “da moda" no período, Metralhadora (16 aluos(as), 84,21\% de N=19), Tá Tranquilo tá Favorável (13 alunos(as), 68,42\% de N=19) e Baile de Favela (10 alunos(as), 52,73\% de $\mathrm{N}=19$ ) são as mais citadas (Tabela 5), mas não necessariamente são as 
que os respondentes mais gostam de ouvir. Dentre as preferências estão Metralhadora (5 alunos(as), 26,32\% de N=19); Tá Tranquilo tá Favorável (4 alunos(as), 21,05\% de N=19). Baile de Favelas foi citada apenas por 2 (10,53\% de N=19) respondentes como música que gosta de ouvir. Essas músicas parecem orbitar em torno das temáticas diagnosticadas, também, entre os(as) estudantes dos estudos piloto: violência, sexo, consumo, festa e utilização de drogas. Estas temáticas são, espantosamente, recorrentes nas músicas destinadas ao público jovem.

Após as aplicações dos questionários diagnósticos e da reflexão prévia acerca dos elementos que poderiam corroborar para as aulas de música, as respostas das questões abertas, principalmente, foram organizadas e categorizadas. Elas apresentam, de forma predominante, resultados qua apontam para a música como lazer, expressão e entretenimento: a música como algo que diverte e distrai.

Saber o que o(a) aluno(a) ouve, onde como, quando e de que maneira auxilia a compreender os seus conhecimentos prévios e sua relação com a música. $O(A)$ aluno(a) associa muito a música ao seu cotidiano e ao lazer como explicitado anteriormente. As preferências e a escuta musical parecem dialogar de maneira plural com o aluno. Autilização da música como escape do cotidiano escolar parece causar no(a) aluno(a), apesar do reconhecimento da importância da escola para o mercado de trabalho, um espaço de conflito e opressão, relacionado ao lazer, à amizade, ao namoro, à identidade juvenil - espaço de vivência extra escolar (DAYRELL; NOGUEIRA; MIRANDA, 2011). Assim, relacionar as atividades musicais à reflexão sobre a própria exclusão e à condição social do contexto escolar, aponta para uma conscientização. Construir uma vivência musical em que o(a) aluno(a) reflita sobre a sua própria condição parece construir uma relação com o pensamento de Freire:

O mundo não é. O mundo está sendo. Como subjetividade curiosa, inteligente, interferidora na objetividade com que dialeticamente me relaciono, meu papel no mundo não é só o de quem constata o que ocorre mas também o de quem intervém como sujeito de ocorrências. Nãosou apenas objeto da História mas seu sujeito igualmente (FREIRE, 1996, p. 85).

As preferências musicais se relacionam com a proposta pedagógica, uma vez que fornecem dados consistentes sobre a vivência e experiência musical do aluno. 


\subsubsection{As preferências musicais}

As preferências musicais dos jovens, de modo geral, podem ser observadas na Tabela 6. Essa apresenta dados sobre os estilos musicais conhecidos pelos(as) alunos(as) e sobre os estilos mais apreciados. $\mathrm{O}$ total de respondentes desta questão foram 14 alunos(as) $(\mathrm{N}=18)$. Vale salientar que, com relação aos estilos, o(a) aluno(a) poderia escolher mais de um estilo tanto referente ao repertório que conhecia quanto relativo à preferência musical.

Dentre os estilos musicais listados no questionário, os(as) respondentes apresentaram respostas contraditórias entre o que conhecem e o que gostam, principalemente, no caso do Choro, quando nenhum aluno(a) afirma conhecer o estilo $(0 \%-0$ de $n=14)$ e 2 respondentes $(13,3 \%, n=14)$ afirmam gostar. Essa ambiguidade ocorre também com o Jazz, $3(20 \%, n=14)$ afirmam conhecer e $9(60 \%, n=14)$ afirmam gostar; o Pop Nacional, $4(26,7 \%, n=14)$ conhecem e $5(33,3 \%, n=14)$ gostam; o Axé, $4(26,7 \%, n=14)$ conhecem e $6(40 \%$ de $n=14)$ gostam; Música de Louvor, $4(26,7 \%, n=14)$ conhecem e $7(46,7, n=14)$ gostam; Rock Nacional, $5(33,3 \%, \mathrm{n}=14)$ conhecem e $9(60 \%, \mathrm{n}=14)$.

Tabela 6 - Preferências Musicais: o que conhecem e o que gostam (n=14 de N=18)

\begin{tabular}{cclll}
\hline Estilo Musical & Conhece & $\%$ & \multicolumn{2}{c}{ Gosta } \\
\hline \hline Funk & 11 & $73.3 \%$ & 7 & $46.7 \%$ \\
Funk Carioca & 2 & $13.3 \%$ & 0 & $0 \%$ \\
Sertanejo & 9 & $60 \%$ & 9 & $60 \%$ \\
Rap & 9 & $60 \%$ & 6 & $40 \%$ \\
Rock Nacional & 5 & $33.3 \%$ & 9 & $60 \%$ \\
Rock Internacional & 3 & $20 \%$ & 3 & $20 \%$ \\
Samba & 5 & $33.3 \%$ & 1 & $6.7 \%$ \\
Pagode & 6 & $40 \%$ & 1 & $6.7 \%$ \\
Forró & 6 & $40 \%$ & 3 & $20 \%$ \\
Hino Gospel & 10 & $66.7 \%$ & 1 & $6.7 \%$ \\
Música de louvor & 4 & $26.7 \%$ & 7 & $46.7 \%$ \\
Reggae & 7 & $46.7 \%$ & 3 & $20 \%$ \\
Axé & 4 & $26.7 \%$ & 6 & $40 \%$ \\
Música Pop & 5 & $33.3 \%$ & 1 & $6.7 \%$ \\
Pop Nacional & 4 & $26.7 \%$ & 5 & $33.3 \%$ \\
Pop Internacional & 4 & $26.7 \%$ & 2 & $13.3 \%$ \\
Música Eletrônica & 9 & $60 \%$ & 4 & $26.7 \%$ \\
Jazz & 3 & $20 \%$ & 9 & $60 \%$ \\
Arrocha & 5 & $33.3 \%$ & 0 & $0 \%$ \\
Música de Orquestra & 3 & $20 \%$ & 2 & $13.3 \%$ \\
Música Instrumental & 2 & $13.3 \%$ & 1 & $6.7 \%$ \\
Bossa Nova & 2 & $13.3 \%$ & 1 & $6.7 \%$ \\
Choro & 0 & $0 \%$ & 2 & $13.3 \%$ \\
Outros: Sofrência & 0 & $0 \%$ & 8 & $53,33 \%$ \\
\hline
\end{tabular}

Fonte: Dados dos questionários de Práticas e Preferências Musicais 
Com relação aos demais estilos a variação de respostas entre o que conhece e o que gosta parece coerente, uma vez que, a relação entre as respostas dos estilos conhecidos e dos preferidos é equivalente ou maior, ou seja, o número de respondentes que afirma conhecer um estilo é igual (Sertanejo e Rock Internacional) ou maior (Funk, Funk Carioca, Rap, Samba, Pagode, Forró, Hino Gospel, Reggae, Música Pop, Pop Internacional, Música Eletrônica, Arrocha, Música de Orquestra, Música Instrumental e Bossa Nova). Dentre os estilos mais conhecidos estão o Funk com $11(73,3 \%, \mathrm{n}=14)$ respondentes; Hino Gospel com 10 (66,7 \%, $\mathrm{n}=14)$ respondentes e Sertanejo, Rap e Música Eletrônica com 9 respondentes $(60 \%, n=14)$. Os mais preferidos não são, necessariamente os mais conhecidos: Sertanejo, Rock Nacional e Jazz foram marcados por $9(60 \%, n=14)$ respondentes. No entanto, $7(46,7 \%, n=14)$ respondentes disseram preferir o Funk e Música de Louvor; o Rap e o Axé são preferidos por $6(40 \%, n=14)$ respondentes. Dentre as respostas dos alunos o termo Sofrência é indicado como estilo musical preferido de $8(53,33 \%, \mathrm{n}=14)$ respondentes.

Aparentemente, os estilos Funk e Funk Carioca foram confundidos nas respostas. O que é contraditório com a resposta do questionário 2, em que os alunos citam músicas de Funk como as mais preferidas: Metralhadora. Além disso, durante as aulas, observei que os(as) alunos(as) não sabem que há uma distinção entre ambos os estilos apesar da nomenclatura similar. Antes da célula de maculelê ser tão amplamente utilizada no funk, a batida ainda obtinha alguma semelhança com as características do pop americano que deriva, em parte, do Funk. Por decorrência das transformações no gênero, este se torna pouco conhecido entre os(as) alunos(as) adolescentes da escola CEF 05 do Paranoá. Tal característica foi elucidada em sala de aula, após o diagnóstico das preferências.

Entre os estilos menos conhecidos estão o Choro com nenhum respondente (0\%); a Bossa Nova, a Música Instrumental e o Funk Carioca com 2 (13,3\%) respondentes e a Música de Orquestra, o Jazz e o Rock Internacional com 3 (20\%) respondentes. Os estilos menos apreciados são: Funk Carioca e Arrocha com nenhum (0\%) respondente; Samba, Pagode, Hino Gospel, Música Pop, Música Instrumental e Bossa Nova com 1 (6,7\%) respondente; Pop Internacional, Música de Orquestra e Choro apresentam 2 (13,3\%) respondentes e Rock Internacional, Forró e Reggae com 3 (20\%) respondentes.

É importante considerar também que os(as) alunos(as) possam se confundir com a nomenclatura dos estilos musicais. Quanto a conhecer um estilo musical eles podem ter marcado nomes que já ouviram e, talvez, não consiguam diferenciar estre os estilos listados 
no questionário. Contudo, as respostas apontam para a necessidade de trabalhar diferenes estilos musicais em sala de aula, apontando suas semelhanças e diferenças.

No questionário de preferências musicais a pergunta "escreva o nome de três musicas que você gosta e porquê" gerou um agrupamento de respostas quando realizada a categorização. Essas categorias poderiam incidir em uma ou mais falas, tal como uma ou mais falas também puderam revelar uma ou mais categorias. Posteriormente, do total de respostas verificou-se a porcentagem da incidência de categorias.

Dentre as categorias emergentes das respostas dos(as) estudantes, algumas categorias aparesentaram maior incidências. Dentre elas destaco:

1) "Bem estar", categoria com nove respostas do número total de respondentes, revelada em respostas como:

Para relaxar, para desestressar, etc.(Q 8).

2) "Entretenimento" com oito respostas em fala como:

Para uma diversão. (Q12).

3) "Transcedência do cotidiano" com seis respostas como em:

Por que elas fazem eu me sentir bem, me fazem pensar o mundo não é totalmente uma merda, pode ser um bom lugar as vezes. (Q1).

4) "Mensagem" com cinco incidências:

Elas são legais e eu fico mais tranquila quando escuto.(Q5).

5) "Memória", "socialização", “identificação pessoal”, "afetividade" ou "visão positiva do mundo", com um respondente afirmou sobre as músicas citadas:

Porque elas são eletrizantes. São muito doidas.(Q11)

Outro dado relevante obtido no questionário foi respondido na pergunta "para que serve a música"? As categorias emergentes e sua incidência foram "expressividade" (11); 
"entretenimento" (7); "bem-estar", "relaxamento", "apreciar ouvindo", "visão artística da música", "gosto" e "identificação" com uma icidência.

Quando relacionamos os dados obtidos nos questionários entre si, é possível observar que os estilos que os(as) alunos(as) conhecem, estão relacionados com as suas músicas preferidas e com àquelas que apontam como as mais famosas. Tanto a questão "para que serve a música" quanto a que pergunta "porque gostam" parecem estar relacionadas com "bem estar" e "entrenimento". As menores incidências observadas estão na visão artística e foram categorizadas na visão artística como "gosto", "identificação", "memória", "socialização".

Esses dados apontam para um outro resultado interessante: apenas um aluno alega ter tido aulas formais de música e de instrumento. Por outro lado, a expressividade musical do(a) aluno(a) é recorrente, inclusive entre os respondentes que alegam compor músicas em casa e tocar algum instrumento. Em qualquer um dos cenários apresentados, há uma possibilidade muita clara de trabalhar a conscientização desses(as) alunos(as). Os dados parecem apontar para uma concepção de que arte considerada veículo para manifestação do sujeito no mundo, o que parece ir ao encontro da possibilidade de construção da conscientização (FREIRE 1979). Para isso, aulas de música que trabalhem o repertório a partir dos conhecimentos préviosdos(as) alunos(as) (ABRAHAMS, 2005) é uma alternativa para estabelecer uma interação entre o seu conhecimento e o conhecimento acadêmico formal (FREIRE; SHOR, 2008).

Outra reflexão pertinente relaciona os estilos musicais preferidos dos(as) alunos(as) com aquelas músicas de moda nos questionários. Há, no entanto, que se tomar cuidado mais uma vez com as generalizações, uma vez que, os alunos apontaram músicas gospels, por exemplo, como músicas prediletas, o que sugere um comportamento moral e cultural relacionado ao cotidiano extraclasse. De toda forma, uma observação muito interessante se refere ao fato de que a aplicação do questionário em si já provou ser um fator didático de conscientização do(a) aluno(a) muito eficaz, uma vez que, ele(a) se viu pensando sobre questões acerca da própria música que ouve todos os dias. Assim, o(a) aluno(a) ao refletir sobre as respostas às questões, se vê frente a sua subjetividade e explora suas vivências e concepções, bem como, percebe suas limitações se percebe como alguém em construção. Curiosamente, as sensibilidade e os preconceitos do professor são postas à prova, uma vez 
que, mediante a cuidadosa observação e cruzamento de dados, poderá haver confirmação de evidências e a necessidade de desconstrução de conceitos.

Quando percebemos um respondente em atitude reflexiva sobre as perguntas abertas e por vezes contraditórias, podemos constatar a complexidade de cada sujeito e o grau de atenção e cuidado que esse(a) aluno(a) demanda.

A dimensão humana, então, se faz necessária e a sensibilidade deve ser encorajada para dialogar com as consequências subjetivas, para que todos os indivíduos em uma sala se descubram.

Não obstante, a dimensão formal dos conhecimentos estruturados pela formação acadêmica, pode e deve ser fornecida a esse aluno, de maneira didática a partir da identificação de suas potencialidades e dificuldades.

Na educação musical, o ser histórico dá suporte, não de maneira horizontal, mas vertical para o ser artístico e musical, capaz, quando for necessário ou quiser, de formalizar essa expressão ou exercitá-la. Assim, em última análise o sujeito histórico será empoderado por se tornar um músico melhor, mais ativo e mais reflexivo. Esse é o motivo pela qual o professor se atém tão profundamente aos(às) alunos(as).

\subsection{AS ATIVIDADES MUSICAIS}

A partir das falas, das respostas e reflexão sobre as preferências musicais, bem como da categorização dos dados. Parti para o planejamento e execução das atividades musicais. Essas foram realizadas em sala de aula e sempre foram acompanhadas de exemplos práticos como explicitado no Capítulo 3. Os exemplos musicais sempre estavam relacionados ao que se discutia em sala de aula. A turma, de uma maneira geral, foi participativa e pareceu assimilar bem as atividades. Como recursos didáticos foram utilizados caixa de som, amplificador, celular.

Durante o desenvolvimento das atividades, busquei intercalar exemplos teóricos e práticos. A turma apresentou uma heterogeneidade de modelos vocais com relação a fluência na execução de vocalises, coros ou palmas. O diagnóstico das habilidades musicais da turma é complexo, uma vez que a perfomance também varia muito por consequência de uma série de fatores como: humor, disposição, concentração, interesse, número de alunos em sala. No 
entanto,os exemplos e atividades práticas com participação da turma são imprescindíveis para a formação musical do(a) aluno(a).

As preferências musicais se relacionaram com a proposta pedagógica, uma vez que fornecem dados consistentes sobre a vivência e experiência musical do aluno e influenciaram as aulas de música. Com base na análise das preferências, na reflexão e nas discussões efetivadas, três aulas de 45 minutos cada foram realizadas. Comecei com uma conversa informal, afim de gerar um ambiente amigável, com discussão sobre os elementos musicais e a função social da música como explicitado no Capítulo 3.

Nesse momento, é interessante estar de posse de algum instrumento, percussivo, melódico ou harmônico, para intercalar exemplos musicais citados ou discutidos com execuções musicais ao vivo. Essa medida permite que os(as) alunos(as) vejam que o professor possui a capacidade prática de exemplificar trechos musicais cantarolando exemplos ou executando fragmentos de melodias. Esse ambiente permite que o aluno se sinta descontraído. Para estes encontros, utilizou-se voz e pandeiro e incentivou-se os(as) alunos(as) a participarem batendo palmas. A descontração desse primeiro momento envolve o(a) aluno(a) e desenvolve uma certa simpatia pela figura do professor.O professor deve estar preparado e disposto à enfrentar momentos de apatia e descrença, principalmente, se tiver diante de uma turma que não tenha tido formação musical. Ele deve estar ciente que certas aproximações devem ser, mais ou menos, paulatinas. Embora os alunos adquiram confiança na figura do professor como mediador do processo de ensino e aprendizagem, ele deve, ainda, estar ciente de que a imprevisibilidade, oriunda de fatores subjetivos, emocionais e psicológicos, interferem com sala de aula.

Por mais planejadas que sejam suas aulas, o professor deve estar preparado para a necessidade de lançar mão de um fator muito relevante para a música: a criatividade que encontra ressonância no improviso. Este pode se desenvolver sobre uma estrutura prévia estabelecida (não cabe aqui qualquer confusão com atividades improvisadas, não planejadas). Ao propor atividades de composição o professor deve está preparado, também, para ser questionado, testado e desafiado pelos(as) alunos(as).

\subsubsection{Composição Musical}


Para refletir: Educação de qualidade. Para transformar: A nossa realidade. Vamos construir uma nova sociedade e acabar com a violência por toda cidade.(Composição dos alunos do $8^{\circ}$ ano A).

A frase da epígrafe foi criada pelos(as) alunos(as) de um dos dois grupos organizado pela turma. Duas aulas foram necessárias para a criação e finalização da composição. Apesar do tempo, os(as) alunos(as) apresentaram uma grande morosidade em relação ao planejamento da atividade. Nas atividades subsequentes, eles(as) apresentaram um maior dinamismo, na medida em que, os(as) alunos(as) passaram a se acostumar com o formato de aula mais participativo e dinâmico. No entanto, a composição inicial foi bem difícil. Os alunos demonstraram boa vontade, mas não pareciam confortáveis com a ideia de serem tão autônomos e participativos.Vários(as) alunos(as) participaram da atividade, porém, não queriam interferir diretamente na letra da composição. Alguns(mas) alunos(as) apresentaram uma certa ansiedade ao se depararem com o fato de que uma letra longa com o ritmo e a melodia seria de difícil execução.

A composição foi sugerida após discussão coletiva acerca da reflexão sobre os conteúdos temáticos das músicas ouvidas e preferidas pelos alunos. Constatou-se que a temática violência era recorrente, ainda que por muitas vezes associadas às questões de entretenimento, festa, consumo de drogas e sexo. A discussão foi conduzida de maneira a apresentar a educação como uma ferramenta de transformação da situação. Sugeri a criação de uma composição que se relacionasse com o cotidiano e a condição do jovem e sua relação com a comunidade e a escola (DAYRELL; NOGUEIRA; MIRANDA, 2011). A proposta de criação musical também encontra particular ressonância no pensamento de Freire (1996), expresso no livro Pedagogia da Autonomia, quando discute o papel do professor para mediar a reflexão sobre a realidade vivida pelos(as) alunos(as)::

Porque não discutir com os alunos a realidade concreta a que se deva associar a disciplina cujo conteúdo se ensina, a realidade agressiva em que a violência é a constante e a convivência das pessoas é muito maior com a morte do que com a vida? Porque não estabelecer uma necessária "intimidade" entre os saberes curriculares fundamentais aos alunos e a experiência social que eles têm como indivíduos? Porque não discutir as implicações políticas e ideológicas de um tal descaso dos dominantes elas áreas pobres da cidade? (FREIRE, 1996 p.16). 
A proposta da composição visou, principalmente, a perspectiva de discussão e conscientização defendida no questionamento de Freire. O conteúdo da letra da composição, ao ser definido, foi desenvolvido por cada grupo que deveria compor uma parte de um RAP. No entanto, houve uma sugestão de que se substituísse o ritmo RAP, tocado no pandeiro, pela célula rítmica do Maculelê que é muito utilizada no Funk Carioca.O ritmo foi executado como base e gravado no celular para que os alunos compusessem sobre a base como já apresentado anteriormente. Nessa fase, os(as) alunos(as), em um primeiro momento, se preocuparam com a execução da letra dentro do pulso da batida sugerida. Não raro, é possível testemunhar a distância entre a composição e a execução, uma vez que, os(as) alunos(as) se sentem muito mais desenvoltos para compor do que para executar. Aquela se relaciona com suas habilidades e esta exige habilidades que muitas vezes os alunos precisa desenvolver

Tal problema parece residir entre outros, no fato de que há uma divergência entre ambas quanto às questões técnicas e concepção. Tal reflexão parece encontrar ressonância em outras realidades vividas em escolas e contextos de ensino e aprendizagem musical. França (2000) observa o processo de composição dos alunos, comparando-o às habilidades de apreciação e execução:

Nas atividades de composição, os limites técnicos dentro dos quais as peças seriam concebidas eram determinados pelas possibilidades dos alunos naquele momento, pois os estímulos oferecidos como ponto de partida não impunham nenhuma limitação técnica - nem do ponto de vista composicional, nem em relação à técnica instrumental. Conseqüentemente, à semelhança do que aconteceu na apreciação, sua compreensão musical pôde se expandir até o nível ótimo de desenvolvimento determinado pela sua maturidade - ou bastante próximo a ele. Se a complexidade técnica das atividades não tivesse sido controlada, provavelmente teríamos verificado resultados mais baixos nessas modalidades ou, pelo menos, mais heterogêneos. (FRANÇA, 2000, p.53)

A autora destaca a adequação da atividade composicional às habilidade técnicas e de compreensão musical dos estudantes investigados. Seus resultados demonstram a relevância da criação musical para a valorização dos conhecimentos musicais dos sujeitos.

$\mathrm{Na}$ atividade realizada no $8^{\circ}$ Ano, um grupo ficou bem empenhado em fazer a letra e me consultaram, diversas vezes, pedindo orientação; o outro grupo demonstrou que não queria contribuir para a letra e protelou ao máximo sua parte na composição, de maneira que, ao término de duas aulas, os(as) alunos(as) não haviam concluído sua parte. No entanto, participaram do áudio batendo palmas. Apesar da baixa produtividade da turma, considerei o 
fato de que os(as) alunos(as), ainda, estavam se adaptando ao formato de aula mais dinâmicas e participativas. Considero, também, que muitos não haviam tido aulas formais de música, o que pode ter sido um fator interveniente, que merece reflexão para o desenvolvimento de estratégias de estímulo e de confiança em atividades futuras.

Da minha parte,houve uma maior parcimônia, a fim de garantir a autonomia e a adaptação gradativa à nova abordagem de aula. Verifiquei, posteriormente, que os(as) alunos(as) lembravam, muitas vezes, das ações realizadas e cantavam e batucavam espontaneamente. Eles(as) pediram para repetir a experiência de composição, o que demonstra que os resultados, por vezes, não vêm no tempo pretendido.

Após a experiência, foi possível avaliar que, apesar da produção dos(as) alunos(as) ter sido tímida e pequena, eles(as) mostraram, positivamente influenciados(as) para se expressarem musicalmente de maneira espontânea. O que indica que, as ações que envolvem composição, a medida em que se tornam mais e mais frequentes, mais elaboradas ficam e os(as) alunos(as) expressam mais autonomia.

\subsubsection{Apreciação Musical: Musicalidade e conscientização}

As atividades de composição foram organizadas sequencialmente de maneira a estabelecer, posteriormente, uma escuta direcionada no sentido de complementar as ações previstas com estilos musicais que os(as) alunos(as) estavam pouco familiarizados. Assim,a música orquestral (e ópera), o jazz e o samba foram associados à composição realizada por eles(as), tendo como eixo o debate crítico social.

A obra musical apreciada e analisada foi a Ópera do Malandro de Chico Buarque de Holanda, especialmente, a canção O Malandro e, por interrelação a canção Mackie Messer (Makie Navalha) da Ópera dos três vinténs de Kurt Weill e Bertold Brech com suas diferentes versões (original, jazz e samba) conforme já explicitado no capítulo 3 (p. 44). Os estilos abordados foram pensados também a partir das amostragens dos questionários de preferências e estilos musicais, notou-se uma baixa incidência de familiaridade, entre outros como esses estilos, a escolha então foi no sentido de associar ao conhecimento prévio dos alunos, novas referências.

A ideia de utilizar fragmentos e ideias musicais recontextualizados não é um exercício que encontra ressonância apenas nos últimos anos da modernidade. Ou seja, a música é uma 
arte que é utilizada como ferramenta de reflexão há muito tempo. O conteúdo dos fragmentos melódicos e rítmicos serviram ainda para ilustrar, de maneira prática, o que preconiza o Currículo em Movimento da Secretaria de Educação do Distrito Federal (SEDF).

A escolha musical se deu para estabelecer um diálogo entre as atividades de composição, temas emergentes na letra e no debate nas aulas sobre a apreciação, para proporcionar a continuidade e a integração das ações proposta. A obra musical escolhida $(\mathrm{O}$ Malandro), além de possibilitar o contato com um compositor de grande significância para a identidade brasileira (Chico Buarque de Holanda), possibilitou uma releitura de forma e estrutura musical inspirada e influenciada pela composição de jazz e de música clássica (Ópera dos três vinténs de Kurt Weill e Bertold Brecht), linguagem pouco usual no cotidiano dos(as) alunos(as), em que a canção O Malandro se baseou. Mas, como já mencionado, as obras são atuais, pois abordam tema e fazem rítica social às situações vigentes na sociedade brasileira atual.

Há ainda uma importante questão a considerar: a reflexão sobre o papel da música como crítica social, política e cultural, relevante como manisfestação histórica da sociedade. Assim, a análise envolve conceitos musicais e sociais de forma integrada. Tal qual encontramos em (ABRAHAMS, 2005).

Assim, buscou-se realizar atividades de introdução de novas referências, execução e composição.

$\mathrm{Na}$ análise dos aspectos formais se destacam a análise de melodias, ritmos, frases e motivos musicais. Os exemplos musicais foram tocados em aparelho de som, em que foram analisados trechos musicais,e não as peças inteiras. Como atividade complementar, sugeri a audição na íntegra das músicas e a pesquisa sobre questões mais pontuais como atividade extra classe. Tal procedimento se baseou no fato de que os alunos possuem acesso à internet.

Nessas aulas de música, a musicalidade e a conscientização são desenvolvidos.

Como vemos em Abrahams: "As atividades de sala de aula despertam a musicalidade nos alunos e permitem que atuem como músicos que pensam, agem e sentem[...]" (2005, p. 67). Assim ainda ao observarmos as práticas associadas ao exercício da pedagogia crítica encontramos mais uma vez: “Ao observar a pedagogia crítica na prática,nós podemos ver também os alunos trabalhando em equipe, em grupos empenhados em resolver ou levantar novos problemas". (ABRAHAMS, 2005 p.67) . 
Os elementos básicos da música como ritmo, melodia e harmonia podem ser ilustrados e construir uma ponte com a crítica social, a atividade demonstra, assim, a riqueza de ideias, conceitos e conhecimentos que envolvem a atividade artística musical. $\mathrm{O}$ teor textual da Ópera do Malandro ambienta um cenário de degradação moral e ética que é recorrente e atemporal. Nessa obra musical, a crítica social e a reflexão sobre o comportamento humano dialogam com outras artes como teatro, artes visuais, sociologia, estética e aspectos estruturais da própria música como: estrutura, forma, textura, motivos melódicos e rítmicos, harmonia e estilo musical.

Nesse tipo de atividade integradora (pesquisa diagnóstica, debate em forma de roda de conversa, composição e apreciação musical), o(a) aluno(a) se vê em um contexto em que está pensando música com uma escuta ativa e reflexiva e não tão somente ouvindo, passivamente, um produto de entretenimento. Desse modo, o professor pode desenvolver um processo de conscientização e empoderamento. 


\section{CONCLUSÃO}

O presente trabalho teve como objetivo refletir sobre os desafios e possibilidades de aulas de música elaboradas para transformar as referências musicais cotidianas dos alunos, não as negando, mas expandindo seu referencial de repertório. Especificamente, este estudo se propôs a: 1) Apresentar quem são os alunos do $8^{\mathrm{a}}$ ano $\mathrm{A}$ e quais são suas preferências e práticas musicais; 2) Descrever e analisar as atividades musicais desenvolvidas em sala de aula tanto para o ensino de elementos musicais quanto para a construção de ferramentas reflexivas que ajudarão o aluno a transformar seu cotidiano e 3)Refletir sobre as "mudanças" de atitude observadas nos alunos.

Para atingir os objetivos propostos, as aulas de música foram realizadas no Centro de Ensino Fundamental 05 (CEF 05) do Paranoá. As atividades consistiram em pesquisa diagnóstica, diálogo por meio de roda de conversa, criação musical (composição coletiva) e apreciação musical, o que possibilitou as reflexões apresentadas nesta monografia. Os procedimentos realizados nas aulas, especialmente a composição, foram registrados em audio.

Com relação ao primeiro objetivo, apresentar quem são os alunos do $8^{\mathrm{a}}$ ano $\mathrm{A}$ e quais são suas preferências e práticas musicais, os questionários diagnósticos aplicados forneceram o perfil socioeconômico e as preferências e as práticas musicais dos(as) alunos(as). Esses(as) têm a idade média de 14,23 anos, moram perto da escola e têm uma grande expectativa com relação ao papel da escola em seu futuro. Os(As) alunos(as) têm uma preferencia musical por Sertanejo, Funk e Rap, mas citam, preferencialmente músicas associadas ao Funk Carioca, apesar de alegarem não gostar deste estilo musical.

Quanto à descrever e analisar as atividades musicais desenvolvidas em sala de aula tanto para o ensino de elementos musicais quanto para a construção de ferramentas reflexivas que ajudarão o aluno a transformar seu cotidiano, segundo objetivo, as aulas de música foram planejadas de forma integradas tendo como referência os dados dos questionários diagnósticos e o trabalho criativo como recurso para fomentar a reflexão dos(as) alunos(as), sua autoestima e empoderamento. A composição, base das atividades realizadas, mostrou o potencial criativo e crítico dos(as) alunos(as), mas também a sua dificuldade em se expressar e dar opiniões próprias, uma vez que estão imersos numa cultura escolar repressora e desmotivadora. A apreciação musical confirmou a importância de se integrar os conhecimentos musicais dos alunos aos conhecimentos formais da sociedade. 
Os alunos apresentaram uma evidente transformação e passaram a compreender melhor a função social e reflexiva da música, o que responde, parcialmente, o terceiro objetivo: refletir sobre as "mudanças" de atitude observadas nos alunos. No desenvolvimento das atividades, observei, também, um incremento no vocabulário musical e na profundidade de análise musical com relação à forma,à estrutura, ao ritmo, à melodia e à harmonia. Os(As) alunos(as) apresentaram um maior conhecimento de termos relativos à música no que se refere à compreensão e distinção deuma variedade de estilos e de ritmos em manifestações musicais. Eles(as) apresentaram, ainda, uma maior confiança e boa vontade em participar das atividades propostas.

A experiência realizada no CEF 5 me incitou, ainda outras reflexões, que apresento a seguir, destacando tanto as características da educação escolar pública e de periferia e o papel do professor.

A educação é sem dúvida uma das maneiras mais eficazes de causar transformações positivas para a humanidade, não obstante, malefícios irreparáveis. Fato é que, uma sociedade que não universalize e promova a melhoria e a busca pela excelência está fadada à dificuldades severas. Na minha experiência como docente, observo que muito se tem lutado para atingir um número cada vez maior de estudantes e alcançar a excelência. Essa busca apoia-se, principalmente, na figura do professor em que reside uma "cultura de sacrifício". Tal cultura apoia-se na figura messiânica do professor que, em sua abnegada obstinação pela justiça social, sacrifica sua própria existência sob a égide da opressão de jornadas desumanas de trabalho, um número brutal de turmas e um número exorbitante de alunos. Essa prática reflete a gestão "cínica" das políticas públicas que transformam o professor de educador em cuidador do maior número possível de crianças. As escolas públicas da periferia no DF, podese dizer, se transformaram em "depósitos" de crianças e adolescentes.

A carga horária do professor, atualmente, exige que o profissional ministre trinta aulas de quarenta e cinco minutos em turmas, em média, de trinta alunos. Na semana, são quinze turmas diferentes e cerca de 600 alunos(as). À carga horária, soma-se o descaso dos colegas e da administração com as aulas de música e a total ausência de estrutura e de materiais.O trabalho docente pode ser qualificado como uma proposital proletarização do ensino. Esta opressão, invariavelmente, é transferida para o(a) aluno(a), seja pela indiferença, seja pela desmotivação de ensinar, seja pela negligência, seja pela imposição de espaços impessoais e opressores. 
Mais particularmente, o CEF 05 do Paranoá parece exacerbar todas os problemas e desafios cotidianos da educação, pois é mais uma escola de periferia, onde professores adoecem, a administração é omissa e falha, há uma absoluta negligência na gestão de recursos humanos e o estado intenta obter o máximo dos seres humanos com o mínimo de recursos. Não é de se estranhar que, qualquer tentativa de reflexão sobre qualquer assunto seja veementemente refutada, incompreendida ou ignorada pela totalidade dos administradores, professores e alunos(as). Tudo isto se perpetua por um motivo bem simples: os professores foram, em sua maioria, educados nesse mesmo ambiente que perpetuam. Há, sem dúvida, na generalização dessa conduta, injustiças com ações individuais e pontuais, em que muitos acreditam estar agindo da melhor forma possível. O interessante é que ao observar os setores da sociedade, essa conduta parece, invariavelmente, embotar a conscientização. Isto porque, a cultura predominante considera a reflexão como algo secundário e contraproducente.

Não é de se admirar que grandes multinacionais, governos, mercado financeiro, indústria de entretenimento e pessoas, extremamente mal-intencionadas, utilizem ferramentas de reflexão e de transformação da sociedade, como a Arte, para justamente esvaziá-la de significado e incutir a ideia de funcionalidade resignada.Pensa-se, então, que a condição humana é fruto do que está posto e obtêm-se muito mais benefícios pessoais se não questionar e desistir dos avanços coletivos. Ora, todos sabem que as invenções e convenções humanas culminam na formação de uma sociedade, em maior ou menor grau, justa. Logo, as convenções podem surgir, ser consagradas ou postas por terra e essas, assim, deveriam ser questionadas pelo constante exercício reflexivo.

A conscientização, dentro da perspectiva de Freire e dos autores abordados nesta pesquisa, parece, ao promover transformação, a saída civilizatória da profunda alienação que se encontram os indivíduos. A não compreensão da importância de uma abordagem educacional baseada na conscientização e na formação de sujeitos reflexivos e comprometidos com a coletividade parece ameaçar os alicerces do que entendemos como sociedade. Para isso, o(a) aluno(a) deve, por intermédio de todo esforço possível, ser encorajado a se tornar um cidadão reflexivo, questionador e atuante, não somente acerca do que aprende, mas do que ensina em sua conduta cotidiana. Para que haja uma efetiva transformação, a cultura da opressão deve ser gradativamente substituída por uma mais eficaz e mais imbuída de conscientização. Curiosamente, a Arte, com seu conteúdo subjetivo, pode, objetivamente, proporcionar ao(à) aluno(a) uma experiência reflexiva e uma prática consciente, em que ele se 
aproprie de qualquer objeto de forma questionadora e o compreenda de maneira autônoma e articulada. Desse modo, poderá proporcionar ao tecido social uma trama mais viva e contestadora.

Mais especificamente, a débil e frágil Educação Musical no país parece carecer de valorização como área do conhecimento e de atuação profissional, pois professores, devidamente formados, ainda não obtêm da cultura escolar reconhecimento e deferência. Além disso, o silêncio da música no currículo escolar, durante a vigência da Educação Artística nas escolas, desfavoreceu a consolidação de um ambiente escolar favorável às aulas de música. Outros fatores somam-se aos citados anteriormente: a evasão escolar, a constante troca de alunos de salas e de escolas, a burocracia da SEDF, o preenchimento dos diários escolares via internet, a falta de internet e de computadores na escola. A população flutuante de alunos(as) é considerável na escola, principalmente, quando a maioria está fora do fluxo escolar. No caso da turma do $8^{\circ}$ ano A, a lista de frequência listava 32 alunos, mas na prática, nas atividades desse projeto participaram18 alunos.A gestão escolar afeta também o trabalho cotidiano do professor. Com relação à carga horária, por exemplo, nos primeiros três meses do ano, ela foi alterada quatro vezes, o que interferiu na seleção da turma e no trabalho desenvolvido com os(as) alunos(as).

Os fatores apresentados interferiram diretamente no meu trabalho e no desenvolvimento desta pesquisa pedagógica. Por isso, considero que os objetivos específicos da pesquisa foram parcialmente atingidos. Contudo, as atividades musicais realizadas comprovam que é possível, mesmo em um contexto adverso, dar aula de música. Porém o sacrifício pessoal, familiar e artístico tornam o ofício de professor de música muito pouco atrativo e de efetividade insuficiente, o que é frustrante.

Especificamente, com relação à turma do $8^{\circ}$ ano $\mathrm{A}$, o desenvolvimento das aulas de música foi realizado na terceira tentativa por causa dos fatores mencionados anteriormente. Primeiramente, um projeto piloto foi feito com o $9^{\circ}$ ano $\mathrm{G}$, depois as atividades aconteceram no $9^{\circ}$ ano P. Essas duas experiências serviram para fazer ajustes e otimizar o tempo e o planejamento das aulas. As dificuldades e desafios apresentados, bem como, os resultados alcançados foram semelhantes nas três situações. Os(As) alunos(as) parecem compreender bem a importância da Arte como possibilidade de exercício reflexivo. Mas para que tal exercício se torne efetivo precisaria haver uma constância nas aulas de música na escola. Um outro aspecto a ser comentado refere-se à heterogeneidade dos conhecimentos musicais que, 
em todas as turmas em que dei aula, parece ser uma constante. Tal heterogeneidade não se constitui, necessariamente, um obstáculo, uma vez que ela enriquece a aula de música e possibilita desenvolver conhecimentos pessoais e conhecimentos formais da cultura musical.

Tudo isso corrobora para que se avalie o contexto musical escolar, pois a música tem muito mais efetividade fora do contexto escolar. A educação musical, sem dúvida, é imprescindível para a construção do exercício reflexivo por parte dos cidadãos, porém é um trabalho que começará a surtir efeito a longo prazo. Indubitavelmente, a área de pesquisa em educação musical é muito promissora e interessante, seu valor para a melhoria da sociedade é real, porém a realização desse propósito, em âmbito escolar, dentro da grade curricular, precisa ser fortalecido por meio de investigações que realmente descrevam a realidade atual e promovam a efetividade das aulas de música na escola. 


\section{REFERÊNCIAS BIBLIOGRÁFICAS}

ABRAHAMS, Frank. Aplicação da Pedagogia Crítica ao ensino e aprendizagem de música. Revista da ABEM, Londrina, v. 13, n. 12, p. 65-72, 2005. Disponível em: $<$ http://www.abemeducacaomusical.com.br/revistas/revistaabem/index.php/revistaabem/articl e/view/337>. Acesso em: 10/08/2015.

. Critical pedagogy in the community music education programmes of Brazil. International Journal of Community Music, v.1, n. 1, p. 117-126, Aug. 2007.

ARROYO, Margarete. Educação musical na contemporaneidade. In: SEMINÁRIO NACIONAL DE PESQUISA EM MUSICA DA UNIVERSIDADE FEDERAL DE GOIÁS (UFG), 2º , 2002, Goiânia, Anais..., Goiânia: UFG, 2002, p. 18-29.

BALL, Stephen J. Vozes/redes políticas e um currículo neoliberal global. Espaço do Currículo, João Pessoa, v.3, n.1, p.485-498, Março a Setembro de 2010.

BARZOTTO, Luis Fernando. Justiça Social - Gênese, estrutura e aplicação de um conceito. Revista Jurídica da Presidência, Brasília,v. 5, n. 48, p.1-17, 2004.

BAUER, Martin W.; GASKELL, George. ed. Pesquisa quantitativa com texto, imagem e som: manual prático. 2. ed. Trad. Pedrino A. Guareshi. Petrópolis: Vozes, 2002, 512p.

BOWMAN, Wayne. Who is the "We"? Rethinking Professionalism in Music Education. Action, Criticism and Theory for Music Education, v 6, na 4, p. 109-131, dez. 2007. Disponível em: <http://act.maydaygroup.org/articles/Bowman6_4.pdf.> Acesso em: $14 / 10 / 2015$.

BRASIL. Ministério da Educação, Base Nacional Comum Curricular (BNCC). Brasília, DF, 2016. Disponível em: <http://basenacionalcomum.mec.gov.br/\#/site/inicio $>$. Acesso em $15 / 06 / 2016$.

BRASIL. Ministério da Educação, Secretaria de Educação Básica (SEB), Secretaria de Formação Continuada, Alfabetização e Diversidade (SECAD). Caderno de Reflexões Jovens de 15 a 17 Anos no Ensino Fundamental. Brasília: Via Comunicação. 2011. 198p. Disponível em:

$<$ http://portal.mec.gov.br/index.php?option $=$ com docman\&view $=$ download\&alias $=8301$ coef2011-caderno-reflexoes\&category slug=junho-2011-pdf\&Itemid=30192> Acesso em: $15 / 06 / 2016$.

BRASIL. Ministério da Educação, Secretaria de Educação Fundamental. Parâmetros Curriculares Nacionais. Brasília, DF: MEC / SEF, 1998. 116 p. disponível em: $<$ http://portal.mec.gov.br/seb/arquivos/pdf/introducao.pdf. Acesso em 10/08/2015>. BRASIL. MEC - INEP. Censo Escolar -Educacenso - O Item Cor/Raça no Censo Escolar da Educação Básica. Brasília, DF, 2015. Disponível em: 
$<$ http://download.inep.gov.br/educacao_basica/educacenso/documentos/2015/cor_raca.pdf > . Acesso em 09/09/2016.

BRASÍLIA, Companhia de Planejamento do Distrito Federal CODEPLAN. Pesquisa Distrital por Amostra de Domicílio - PDAD. Brasília, DF, 2016. Disponível: $<$ www.codeplan.df.gov.br>. Acesso em:11/11/2015.

BRASÍLIA, Secretaria de Estado de Educação do Distrito Federtal (SEDF). Censo Escolar 2015. Brasília, DF, 2015. Disponível em: $<$ http://portal.inep.gov.br/>. Acesso em: $10 / 10 / 2015$.

BRASÍLIA, Secretaria de Estado de Educação do Distrito Federtal (SEDF). Censo Escolar 2016. Brasília, DF, 2016. Disponível em: <http://portal.inep.gov.br/>. Acesso em: $10 / 10 / 2015$.

DAYRELL, Juarez. O jovem como sujeito social. Revista Brasileira de Educação, n. 24, p. 40-52, 2003. Disponível em:

$<\mathrm{http}: / /$ www.scielo.br/scielo.php?script=sci_arttext\&pid=S1413-

$24782003000300004 \& \operatorname{lng}=\mathrm{pt} \& \mathrm{nrm}=\mathrm{iso} \& \mathrm{tlng}=\mathrm{pt}>$. Acesso em 15/03/2016.

DAYRELL, Juarez; NOGUEIRA, Paulo Henrique de Queiroz; MIRANDA, Shirley Aparecida de. Os Jovens de 15 a 17 anos: Características eEspecificidades Educativas In BRASIL, Ministério da Educação, Secretaria de Educação Básica (SEB), Secretaria de Formação Continuada, Alfabetização e Diversidade (SECAD). Caderno de Reflexões Jovens de 15 a 17 Anos no Ensino Fundamental. Brasília: Via Comunicação. 2011. 198p. Disponível em:

http://portal.mec.gov.br/index.php?option=com docman\&view=download\&alias=8301coef2011-caderno-reflexoes\&category_slug=junho-2011-pdf\&Itemid=30192 Acesso em: $15 / 06 / 2016$.

DEMO, Pedro. Pobreza Política: a pobreza mais intensa da pobreza brasileira. Campinas: Autores Associados, 2006.

DYNDAHL, Petter; KARLSEN, Sidsel; WRIGHT, Ruth. Exploring the Sociology of Music Education. Action, Criticism \& Theory for Music Education. Sociology of Music Education, Special Issue. v. 13, no 1, p. 1-12, march 2014. Disponível em:

$<$ http://s3.amazonaws.com/academia.edu.documents/33295253/DyndahlKarlsenWright13_1.p df? AWSAccessKeyId $=$ AKIAIWOWYYGZ2Y53UL3A\&Expires $=1487711239 \&$ Signature $=8$ COMa7u\%2FyRUJ5Kr7dxXf6DeBwuM\%3D\&response-contentdisposition=inline $\% 3 \mathrm{~B} \% 20$ filename\%3DExploring the Sociology of Music Educati.pdf. $>$ Acesso em: 21/02/2016.

FRANÇA, Cecília Cavalieri. Performance instrumental e educação musical: a relação entre a compreensão musical e a técnica. Per Musi. Belo Horizonte, v.1, p. 52-62, 2000.

FREIRE, Paulo. Conscientização: teoria e prática da libertação: uma introdução ao pensamento de Paulo Freire. Tradução de Kátia de Mello e Silva; revisão técnica de Benedito Eliseu Leite Cintra. São Paulo: Cortez \& Moraes, 1979. 
.Pedagogia da autonomia: saberes necessários à prática educativa. São Paulo: Paz e Terra, 1996. (Coleção Leitura).

.Política e educação : ensaios. $5^{\text {a }}$ Ed. São Paulo: Cortez, 2001. Coleção Questões de Nossa Época, v.23.

FREIRE, Paulo; SHOR, Ira. Medo e ousadia: o cotidiano do professor. Trad. Adriana Lopez. Revisão técnica de Lólio Loureiro de Oliveira. Rio de Janeiro: Paz e Terra, 1986. Coleção Educação e Comunicação. v. 8.

GARRIDO, Elsa; BRZEZINSKI, Iria. A reflexão e investigação da própria prática na formação inicial continuada: contribuição das dissertações e teses no período 1997-2002. Revista Diálogo Educacional, Curitiba, v. 8, n. 23, p. 153-171, jan./abr. 2008.

GIACOMELLI, Megan Leigh. Theorising Improvisation as a form of Critical Pedagogy in Ontario Public School Music Curricula. Critical Studies in Improvisation/Études Critiques en Improvisation, v. 8, $\mathrm{n}^{\mathrm{o}}$ 1, p.1-11, 2012.

GIROUX, Henry A. Escola crítica e política cultural. 2º ed. São Paulo: Cortez, 2001.

HALL, Stuart. A identidade cultural na pós-modernidade. Trad. Tomas Tadeu da Silva e Guacira Lopes Louro. 11 ${ }^{\mathrm{a}}$ ed. Rio de Janeiro: DP\&A, 2006. 102p.

JOHANSSON, Karin (Org.) Conference Crossing borders: Nordic research in music education in an international perspective. Malmö Academy of Music: Lund University, April $21-23,2010$.

KASCHUB, Michele. Critical pedagogy for creative artists: Inviting young composers to engage in artistic social action. In: GOULD, Elizabeth et al. Exploring social justice: how music education might matter. Toronto: Canadian Music Educators' Association/ L'Association canadienne des musiciens éducateurs, 2009. Volume 4 of the Biennial Series, Research to Practice.

LANKSHEAR, Colin; KNOBEL, Michel. (eds.) Pesquisa pedagógica: do projeto à implementação. Porto Alegre: Artmed, 2008.

MIETTINEM, Laura. Music, media and social critique: implications of critical pedagogy for music education. In: RIKANDI, Inga (ed.), Mapping the Common Ground: Philosophical Perspectives on Finnish Music Education. Helsinki: BTJ, 2010, p. 146-159.

MORAES, Abel. Multifrenia na educação musical: diversidade de abordagens pedagógicas e possibilidades para as profissões da música. Revista da ABEM, Porto Alegre, n. 14, março p. 55-64, 2006.

OLIVEIRA, Alda de Jesus. A educação musical no Brasil: ABEM. Revista da ABEM. Porto Alegre, v.1, n. 1, p. 35-40, 1992. Disponível em: 
$<$ http://www.abemeducacaomusical.com.br/revistas/revistaabem/index.php/revistaabem/articl e/view/513>. Acesso em 24/02/2016.

PEREIRA, Llítsia Moreno. Educação musical na escola pública: um olhar sobre o projeto "Música para todos”. Dissertação de Mestrado em Educação. Porto Velho: UFRO, 2011.

PHILPOTT, Chris; SPRUCE, Gary. Debates in music teaching. Abingdon: Routledge, 2012.

ROMANOWAKI, Joana Paulin; ENS, RomildaTeodora. As pesquisas denominadas do tipo "Estado da Arte" em Educação. Revista Diálogo Educacional, Curitiba, v. 6, n. 19, p. 37-50 set-dez 2006.

SANTOS, Boaventura de Sousa. Os Processos da Globalização. Revista Crítica de Ciências Sociais, Ago 2002, Disponível em: http://www.eurozine.com/os-processos-da-globalizacao/. Acesso em: Acesso em 24/02/2016.

SPRUCE, Gary. Musical knowledge, critical consciousness and critical thinking. In: PHILPOTT, Chris; SPRUCE, Gary (eds). Debates in Music Teaching. Debates in Subject Teaching. Abingdon: Routledge, 2012, p. 185-196. 
APÊNDICE A: FOTOS DA ESCOLA

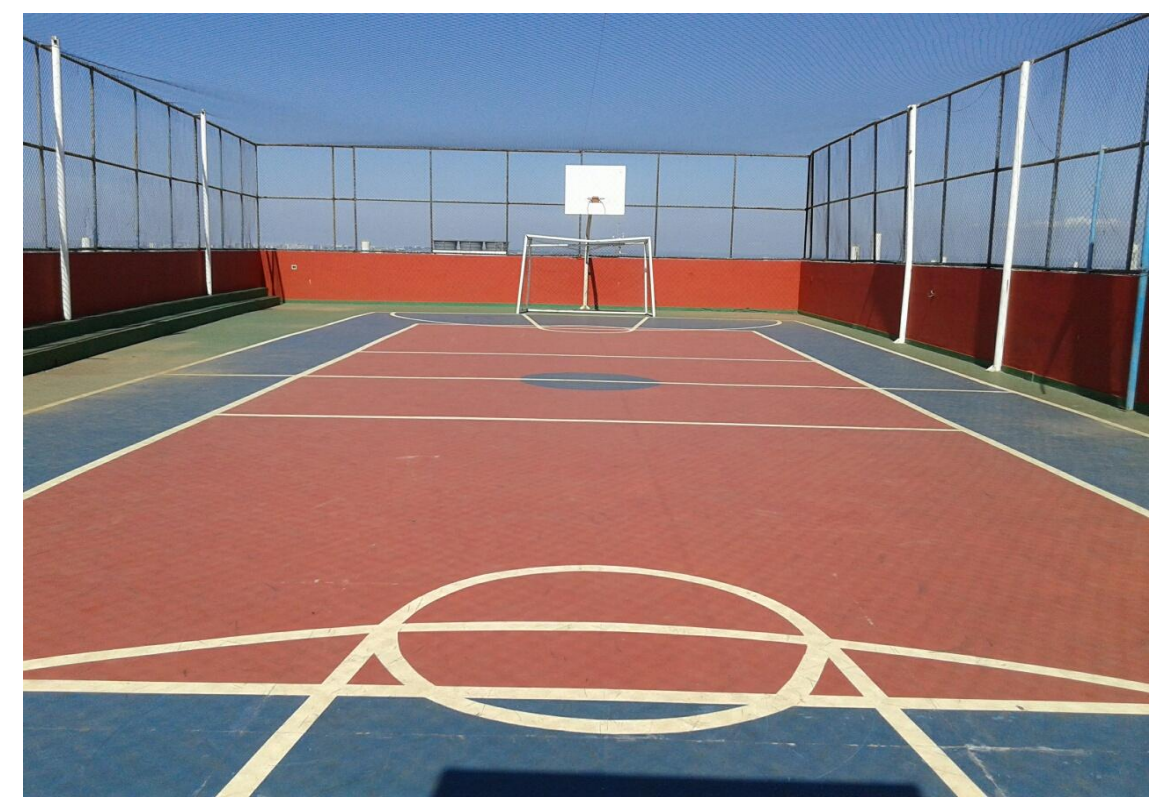

Figura 1: Quadra Esportiva localizada no terraço Fonte: Acervo do Autor

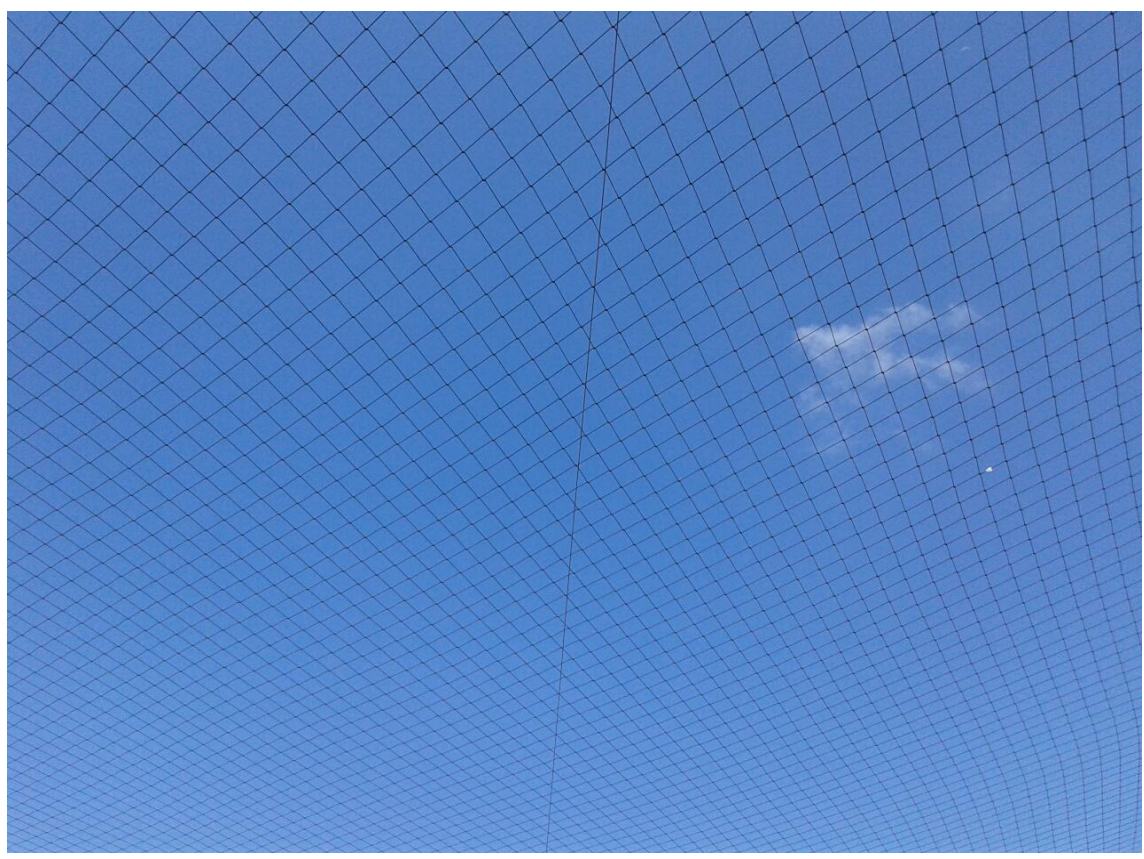

Figura 2:Foto da tela de proteção superior da quadra Fonte: Acervo do Autor 


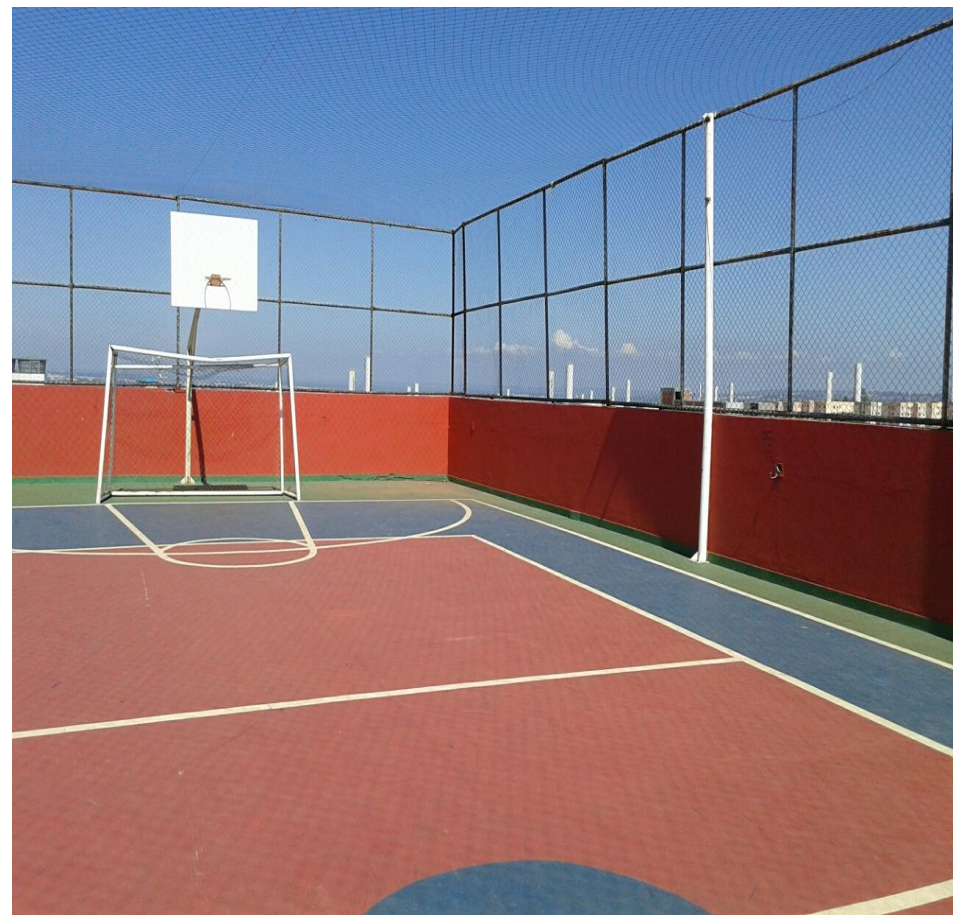

Figura 3: Foto da quadra esportiva Fonte: Acervo do Autor

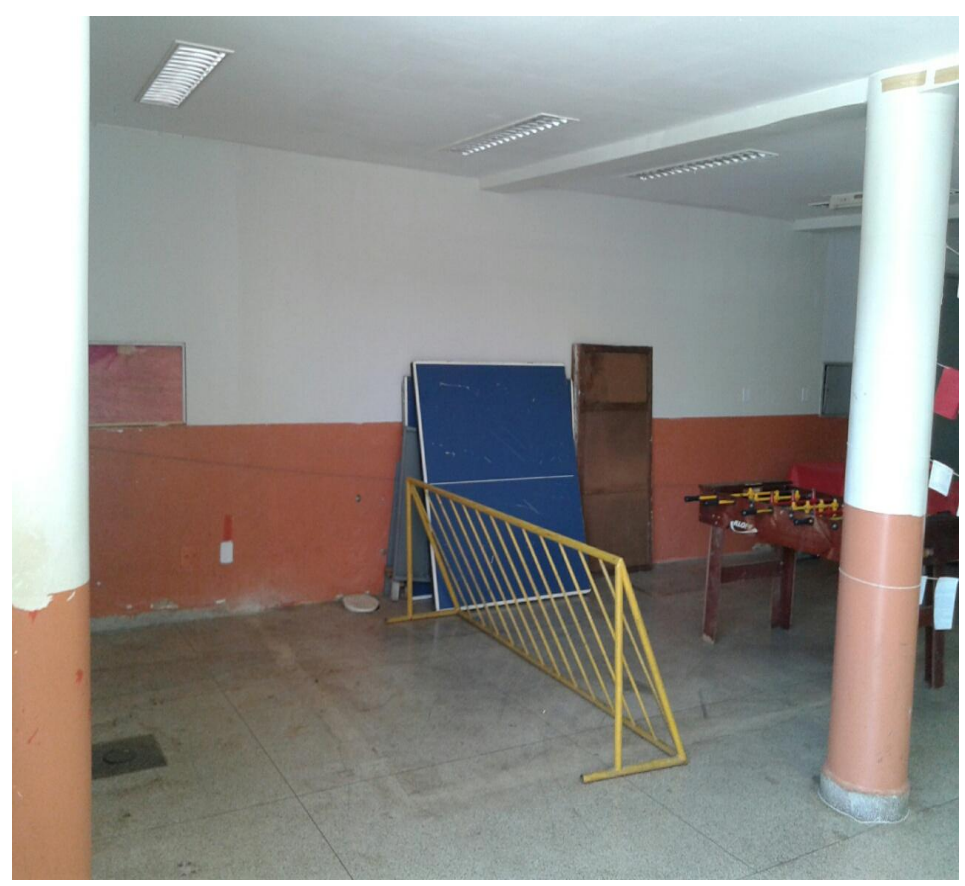

Figura 4: Foto recreação

Fonte: Acervo do Autor 


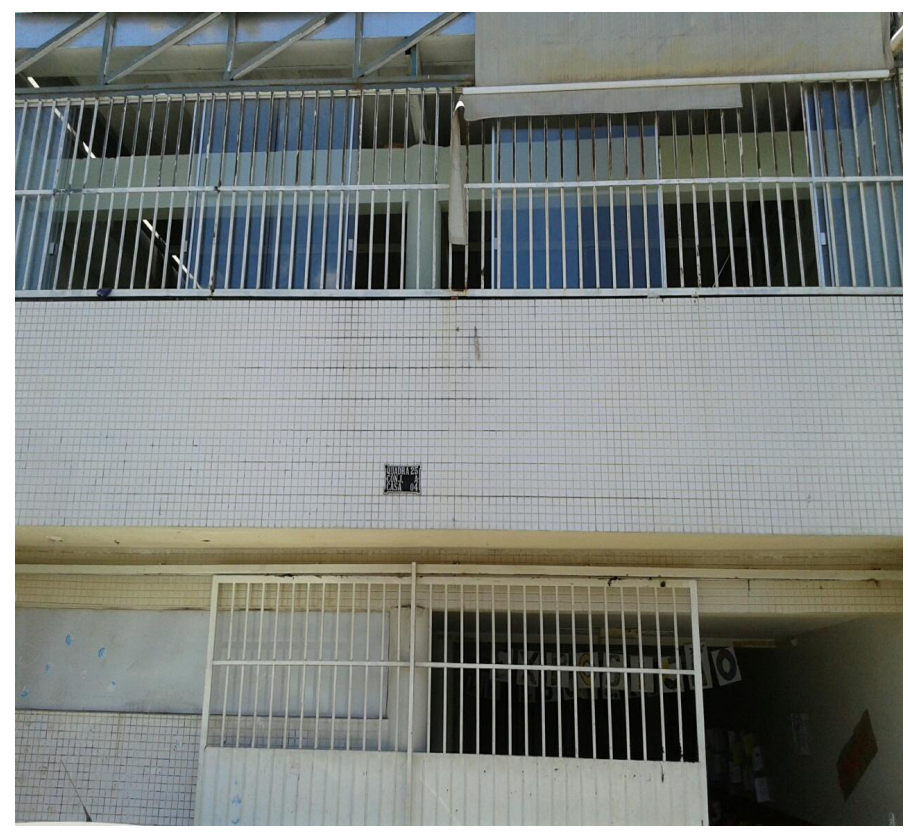

Figura 5: Fachada

Fonte: Acervo do Autor

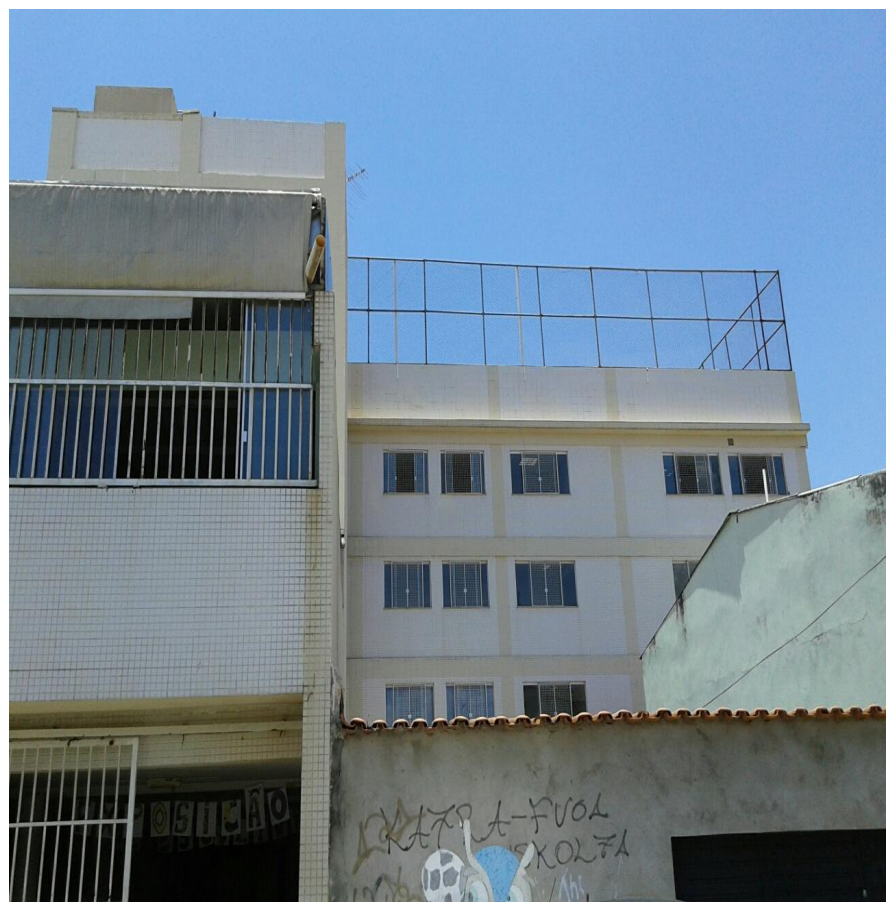

Figura 6: Fachada

Fonte: Acervo do Autor 


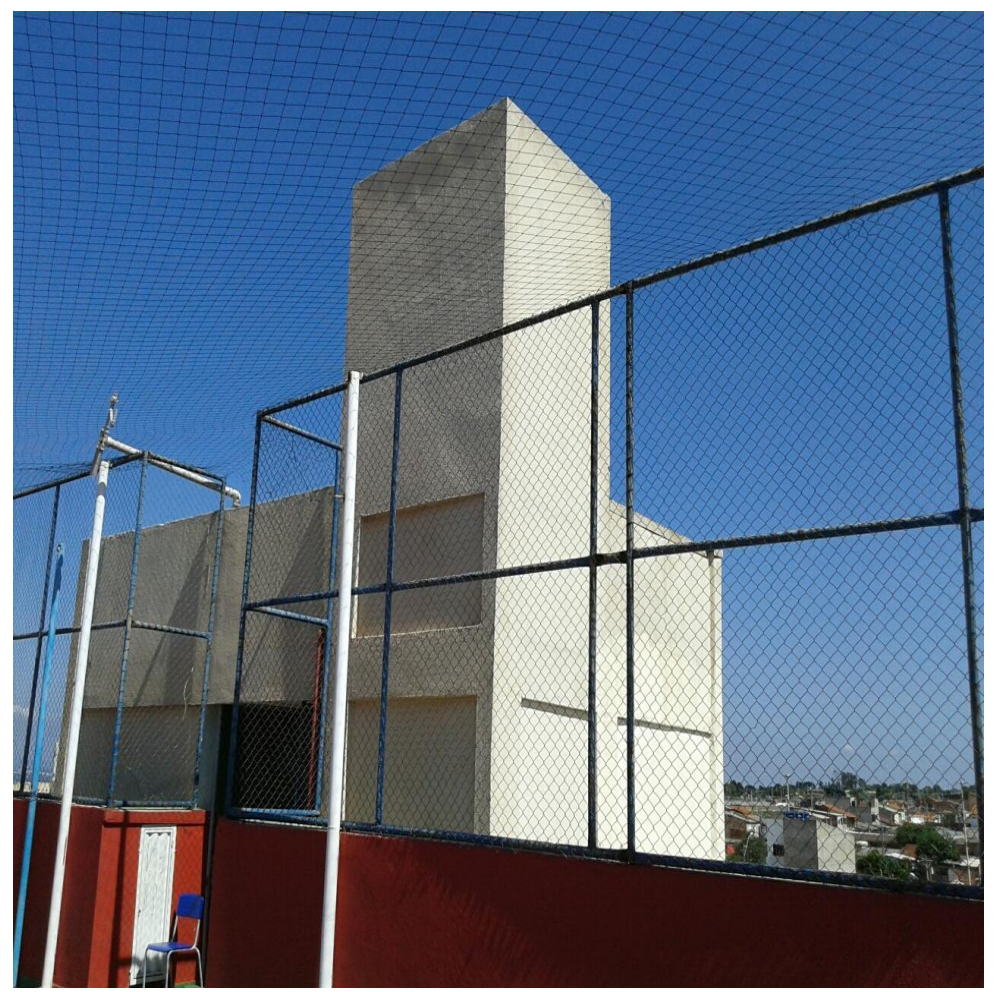

Figura 7: Vista

Fonte: Acervo do Autor

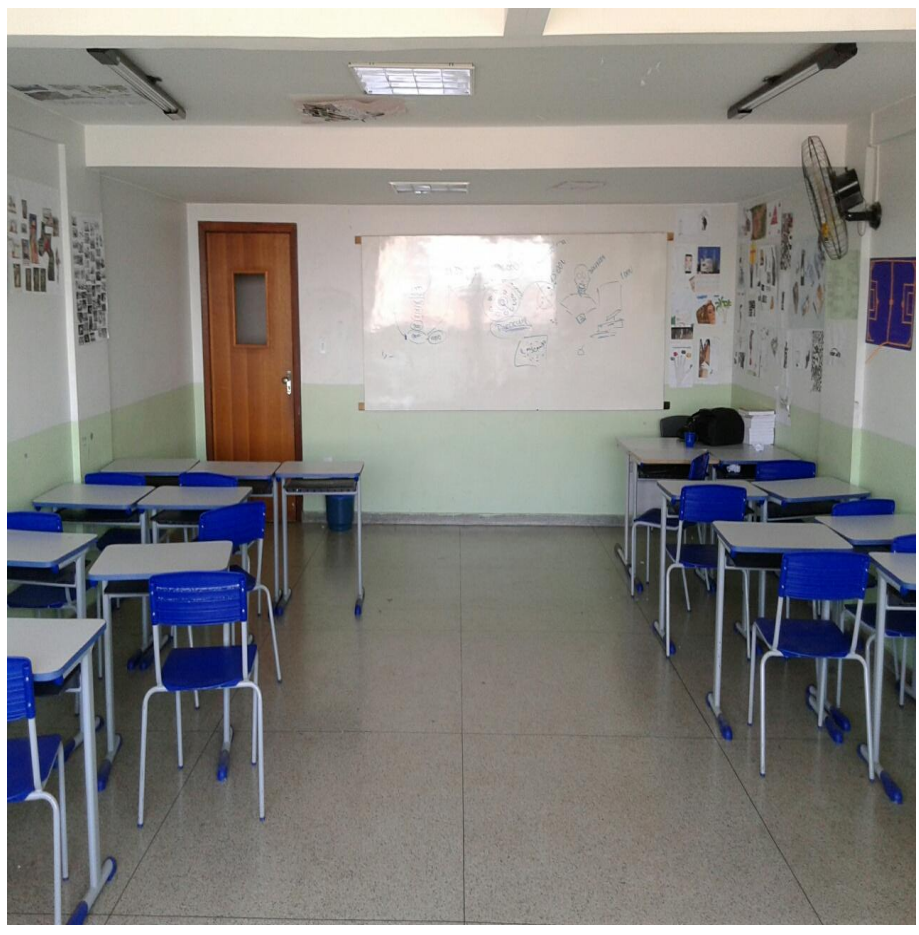

Figura 8: Sala de Aula

Fonte: Acervo do Autor 


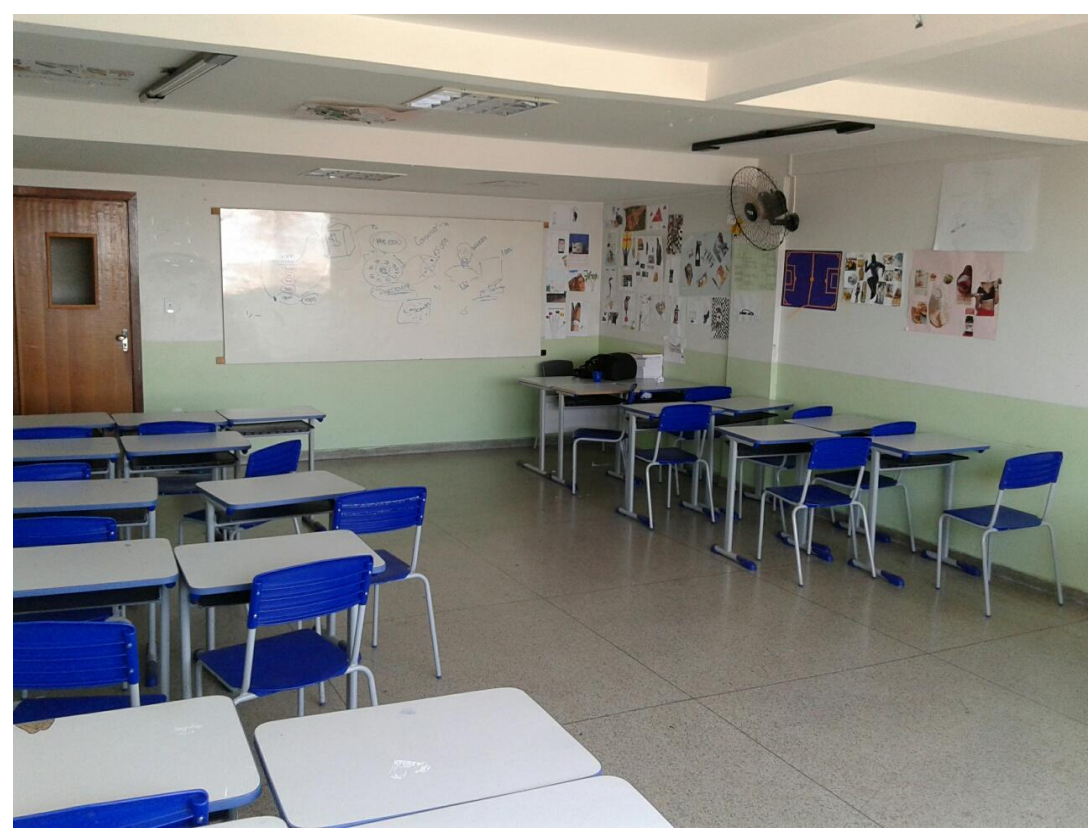

Figura 9: Sala de Aula

Fonte: Acervo do Autor 


\section{APÊNDICE B: QUESTIONÁRIO DIAGNÓSTICO SÓCIO ECONÔMICO}

Ordem do Questionário:

1 Qual a sua idade?

2 Quantas pessoas moram com você?

3 Você se considera:

( ) Branco ( )Preto ( )Pardo ( ) Amarelo ( ) Indígena

4 Você possui filhos?

( ) $\operatorname{Sim}$ ( ) Não

5 Você trabalha?

( ) $\operatorname{Sim}$ ( ) Não

6 Em qual Estado você nasceu?

7 Qual cidade ou bairro você mora?

8 Você possui acesso à internet ?

( ) $\operatorname{Sim}$ ( ) Não

9 A que horas acorda para vir à escola?

10 Quanto Tempo você demora para se deslocar até a escola?

11 Você acha que o estudo vai fazer alguma diferença na sua vida?

( ) Nada ( ) Pouco importante ( ) Mais ou menos ( ) Importante

( ) Muito importante

12 Justifique (Relativo a pergunta anterior):

13 Até qual grau de escolaridade você pretende fazer?

( ) Ensino fundamental ( ) Ensino médio ( ) Ensino superior

14 Em sua opinião de que forma a escola pode contribuir positivamente para sua comunidade?

15 De que forma sua aprendizagem seria melhor avaliada? 
16 Cite duas experiências boas na sua vida escolar: 1

17 Cite duas experiências ruins na sua vida escolar:

18 Quais atividades você gostaria que o CEF 05 desenvolvesse?

19 Em que você pode contribuir para melhor convivência no ambiente educacional?

20 Apresente-se...Quem é você?

21 Como foi seu desempenho como estudante no último ano que você estudou?

22 Como você pretende ser nesse ano de 2016 ? 


\section{APÊNDICE C: QUESTIONÁRIO DIAGNÓSTICO PREFERÊNCIAS MUSICAIS}

1. Nome:

2. Ordem do questionário:

3. Para que serve a Arte?

4. Para que serve a música?

5. Escreva o nome de três músicas que estão na moda.

6. O que é música para você?

7. Escreva o nome de três músicas que você gosta.

8. Explique porque você gosta dessas músicas 


\section{APÊNDICE D: QUESTIONÁRIO DIAGNÓSTICO PRÁTICAS E PREFERÊNCIAS MUSICAIS}

O questionário tem perguntas de múltipla escolha, perguntas em que você pode escolher mais de uma opção e perguntas abertas, em que você poderá dar sua opinião.

Ordem do Questionário:

1 Nome:

2 Sexo - Marcar apenas uma opcão.

( ) Feminino ( ) Masculino ( ) Prefiro não declarar

3 Assinale os estilos musicais que você conhece. (Você pode escolher mais de uma opção)Marque todas que se aplicam.

( ) Funk ( ) Funk Carioca ( ) Sertanejo ( ) Rap ( ) Rock Nacional

( ) Rock Internacional （ ) Samba （）Pagode （ ) Forró （ ) Hino Gospel

( ) Música de Louvor （）Reggae （）Axé （ ) Música Pop （）Pop Nacional

( ) Pop Internacional （ ) Música Eletrônica （ ) Jazz （）Arrocha

( ) Música de Orquestra ( ) Música Instrumental ( ) Bossa Nova （ ) Choro

( ) Outro:

4 Assinale os estilos musicais que você GOSTA de ouvir . (Você pode escolher mais de uma opção). Marque todas que se aplicam.

( ) Funk ( ) Funk Carioca ( ) Sertanejo （ ）Rap （）Rock Nacional

( ) Rock Internacional （ ) Samba （）Pagode （）Forró （）Hino Gospel

( ) Música de Louvor ( ) Reggae ( ) Axé （ ) Música Pop （ ) Pop Nacional

( ) Pop Internacional （ ) Música Eletrônica （ ) Jazz （）Arrocha

( ) Música de Orquestra （）Música Instrumental（）Bossa Nova （ ) Choro

( ) Outro:

5 Que atividades você gosta de fazer ouvindo música? (Você pode escolher mais de uma opção). Marque todas que se aplicam.

( ) Não faço nada, apenas escuto. ( ) Tomar conta de meus irmãos mais novos.

( ) Tomar conta de meu filho e/ou de minha filha. ( ) Cuidar dos meus avôs. 
( ) Fazer tarefas domésticas. ( ) Estudar. ( ) Assistir aula.

( ) Jogar no computador ou no celular. ( ) Navegar na internet e interagir nas redes sociais.

( ) Malhar e praticar esportes. ( ) Conversar com amigos no celular.

( ) Tomar banho e me arrumar. ( ) Enquanto trabalho. ( ) Outro:

6 Em que lugares você escuta música? (Você pode escolher mais de uma opção) Marque todas que se aplicam.

( ) Em casa ( ) Na casa de parentes ( ) Na escola ( ) No trabalho

( ) Na Igreja ( ) No carro ( ) No ônibus ( ) Em festas ( ) No shopping

( ) Em restaurantes ou lanchonetes ( ) Em shows ( ) Nos teatros

( ) Em festivais de música ( ) Em concursos de música ( ) Outro:

7 Quais as mídias você utiliza para ouvir música? (Você pode escolher mais de uma opção). Marque todas que se aplicam.

( ) Rádio ( ) Televisão ( ) Aparelho de Som （ ) Celular ( ) MP3 ou MP4

( ) Internet ( ) Outro:

8 Você canta? Marcar apenas uma oval.

( ) SIM (Ir para a pergunta 10). ( )NÃO (Ir para a pergunta 11).

Resposta Afirmativa.

9 Em que contexto realiza essa atividade?Marque todas que se aplicam.

( ) Canto informalmente (em casa, no chuveiro, no carro, etc) ( ) Canto em Coral

( ) Canto em banda ( ) Canto em Karaokê （ ) Outro:

10. Você toca algum instrumento?Marcar apenas uma opção.

( ) SIM ( ) NÃO (Ir para a pergunta 13).

Para Resposta Afirmativa

11. Em que contexto realiza essa atividade? Marque todas que se aplicam.

( ) Toca informalmente (em casa, no chuveiro, no carro, etc) ( ) Toca Solo (sozinho)

( ) Toca em orquestra ( ) Toca em banda ( ) Toca em pequenos grupos

( ) Outro:

12. Você faz composições ou arranjos musicais?Marcar apenas uma opção.

( ) SIM ( ) NÃO (Ir para a pergunta 15). 
Resposta Afirmativa

13. Que tipo de composição você realiza?Marque todas que se aplicam.

( ) Composição ou arranjo para voz e instrumentos musicais.

( ) Composição ou arranjo para orquestra. ( ) Composição ou arranjo para banda.

( ) Composição ou arranjo para pequenos grupos. ( ) Outro:

14. Você estuda ou estudou Música (Marcar apenas uma oval).

( ) SIM (Ir para a pergunta 16). （ )NÃO (Ir para a pergunta 18). ( )Já estudei. (Ir para a pergunta 17).

Resposta Afirmativa

15. Como você estuda música? Marque todas que se aplicam.

( ) Sozinho ( ) Com parentes ( ) Com revistas ( ) Com vídeos

( ) Com professor particular ( ) Com professor na escola regular de ensino

( ) Com professor em escola de música ( ) Outro:

Resposta Já estudei

16. Como você já estudou música?Marque todas que se aplicam.

( ) Sozinho. ( ) Com parentes ( ) Na Internet ( ) Com revistas

( ) Com professor particular ( ) Com professor em escola regular de ensino

( ) Com professor em escola de música ( ) Outro:

17. Quando você ouve música em que você presta atenção? (Marque todas que se aplicam).

( ) Letra de música. ( ) Melodia ( ) Batida rítmica ( ) Harmonia

( ) Instrumentação ( ) Estilo ( ) Estrutura e forma ( ) Contexto social e cultural

( ) Contexto histórico ( ) Em nada ( ) Outro: 


\section{APÊNDICE E: EXEMPLO ANÁLISE DADOS QUESTÕES FECHADAS}

Questionário Socio-Econômico
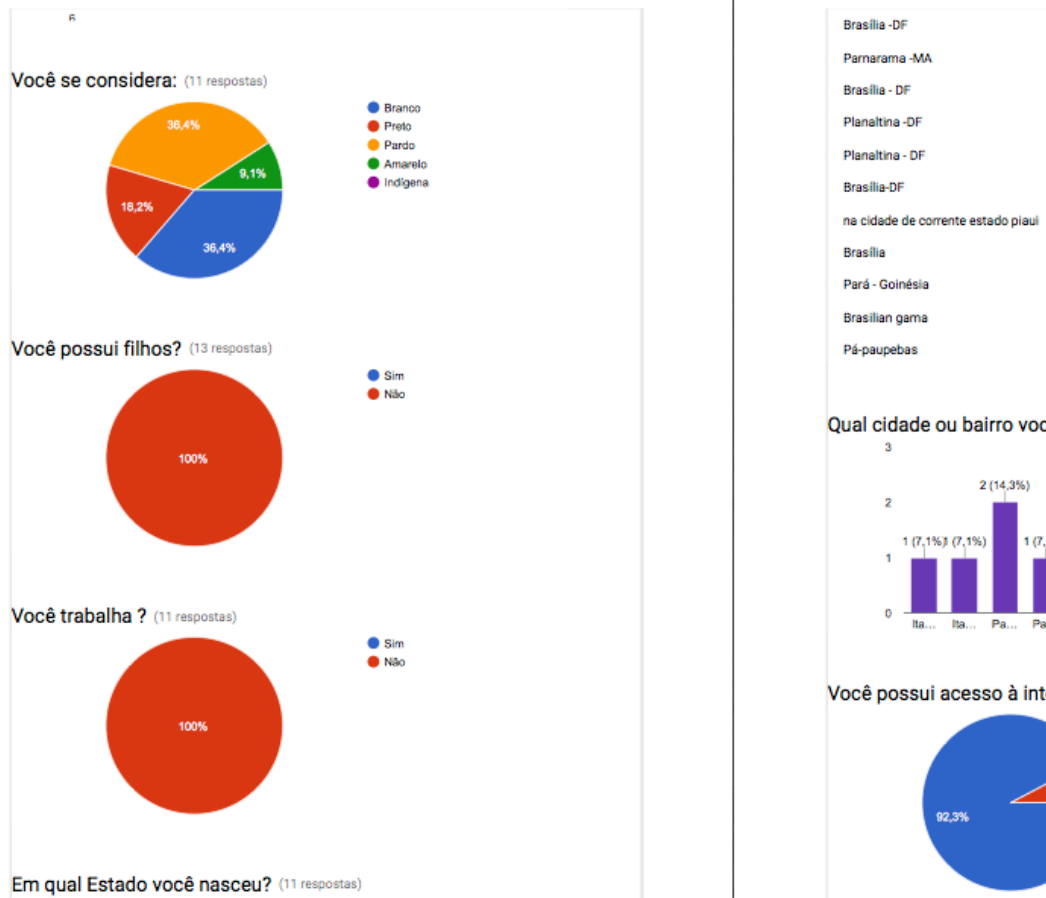

Qual cidade ou bairro você mora? (12 respostas)

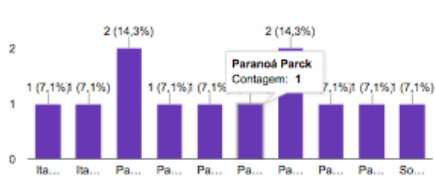

Você possui acesso à internet ? (13 respostas)

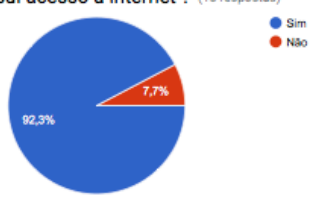

A que horas acorda para vir à escola? (13 respostas)

Questionário Preferências Musicais
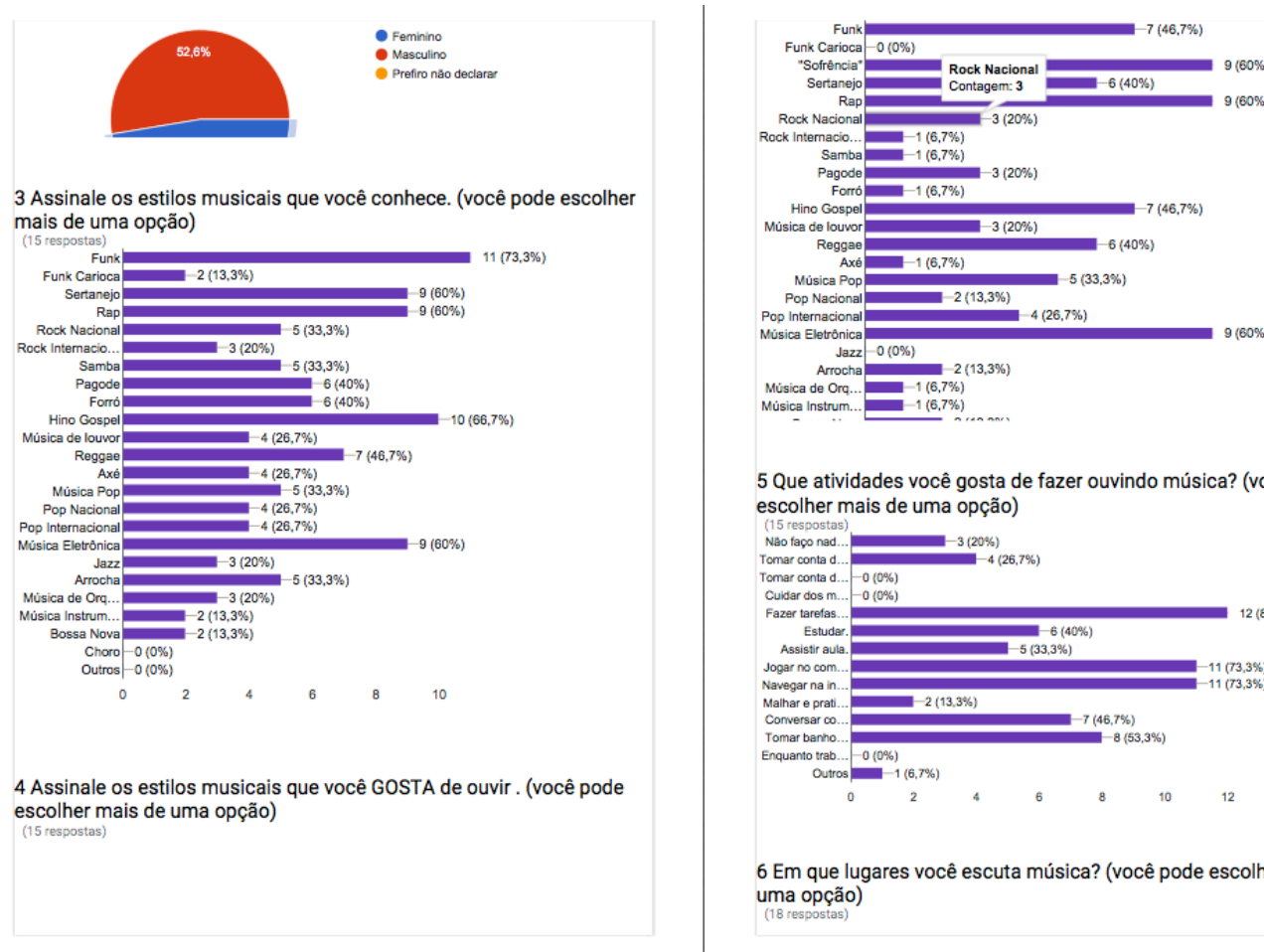

5 Que atividades você gosta de fazer ouvindo música? (você pode escolher mais de uma opção)

(15 respostas)

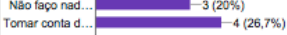

Tomar conta c.... $-0(0 \%)$

Cuibar dos $m . . .-0(0 \%)$

- 6 (40\%)

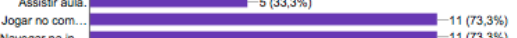

Navegar na in...

Malhar e prati... 2 (13.3\%)

Conversar co.... $7(46,7 \%)$

Tomarbano 0 (10\%)

Enquarito trab...- 0 (0\%)

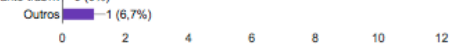

6 Em que lugares você escuta música? (você pode escolher mais de uma opção) 


\section{APÊNDICE F: EXEMPLO ANÁLISE DADOS QUESTÕES ABERTAS}

\begin{tabular}{|c|c|c|c|c|}
\hline $\mathbf{N}^{\mathbf{o}}$ & QUESTÃO & $\mathbf{Q}$ & QUESTÃO & \multirow{2}{*}{ CATEGORIAS } \\
\hline & $\begin{array}{l}\text { Escreva o nome de três } \\
\text { músicas que você gosta. }\end{array}$ & & $\begin{array}{c}\text { Explique porque você gosta } \\
\text { dessas músicas }\end{array}$ & \\
\hline Q1 & $\begin{array}{l}\text { Beautifull, When she's gone. } \\
\text { Envolvidão. }\end{array}$ & $\begin{array}{l}1 \\
1 \\
1\end{array}$ & $\begin{array}{l}\text { Por que elas fazem eu me sentir } \\
\text { bem, me fazem pensar o mundo } \\
\text { não é totalmente uma merda, pode } \\
\text { ser um bom lugar as vezes. }\end{array}$ & $\begin{array}{l}\text { Bem estar; } 1 \\
\text { Visão positiva do mundo 1; } \\
\text { Transcendência do } \\
\text { cotidiano 1; }\end{array}$ \\
\hline Q2 & $\begin{array}{l}\text { Bob voltou. } \\
\text { Viva seu melhor. } \\
\text { Mc Krum Vera Cruz. }\end{array}$ & $\begin{array}{l}1 \\
1 \\
1\end{array}$ & $\begin{array}{l}\text { Para eu lembrar de meus amigos e } \\
\text { também para passar o tempo. }\end{array}$ & $\begin{array}{l}\text { Memória 1; afetividade 1; } \\
\text { lazer/ entretenimento 1; } \\
\text { Socialização 1; }\end{array}$ \\
\hline Q3 & Raridade. & 1 & $\begin{array}{l}\text { Porque ela expressa alguma coisa } \\
\text { legal. Eu gosto porque tem umas } \\
\text { bem legal. Para ficar alegre. }\end{array}$ & $\begin{array}{l}\text { Bem estar; } 2 \\
\text { Entretenimento 2; }\end{array}$ \\
\hline Q4 & $\begin{array}{l}\text { Sempre vida loka, depois da zero, } \\
\text { Jesus chorou. }\end{array}$ & $\begin{array}{l}1 \\
1 \\
1\end{array}$ & Por que eu gosto das letras. & $\begin{array}{l}\text { Mensagem letra 1; } \\
\text { Elemento musical - letra 2; }\end{array}$ \\
\hline Q5 & $\begin{array}{l}\text { O escudo. } \\
\text { Advogado fiel. } \\
\text { O maior troféu. }\end{array}$ & $\begin{array}{l}1 \\
1 \\
1\end{array}$ & $\begin{array}{l}\text { Por quê são músicas decentes que } \\
\text { fala das coisas boas da vida e não } \\
\text { fica, falando de porcarias. }\end{array}$ & $\begin{array}{c}\text { Mensagem letra 3; } \\
\text { Transcendência do } \\
\text { cotidiano } 2\end{array}$ \\
\hline Q6 & $\begin{array}{c}\text { Baile de Favela. } \\
\text { Metralhadora. } \\
\text { Tá tranquilo, ta favorável. }\end{array}$ & $\begin{array}{l}1 \\
1 \\
1\end{array}$ & $\begin{array}{l}\text { Elas são legal e eu fico mais } \\
\text { tranquila quando escuto. }\end{array}$ & $\begin{array}{c}\text { Bem estar 3; Mensagem } \\
\text { letra 4; } \\
\text { Entretenimento } 3\end{array}$ \\
\hline Q7 & $\begin{array}{c}\text { Eu te amo sexta-feira. } \\
\text { Se cuida. } \\
\text { Love Yourself. }\end{array}$ & $\begin{array}{l}1 \\
1 \\
1 \\
\end{array}$ & $\begin{array}{c}\text { Porque me faz crescer a cada toque } \\
\text { dessas músicas, me faz sentir bem } \\
\text { quando estou triste. }\end{array}$ & $\begin{array}{c}\text { Bem estar } 4 \\
\text { Transcendência do } \\
\text { cotidiano } 3 \\
\end{array}$ \\
\hline Q8 & $\begin{array}{l}\text { Eu não gosto muito de ouvir } \\
\text { música. }\end{array}$ & 1 & Não respondeu & Não respondeu 1 \\
\hline Q9 & $\begin{array}{c}\text { Baile de Favela. } \\
\text { Metralhadora. } \\
\text { Tá tranquilo tá favorável. } \\
\end{array}$ & $\begin{array}{l}2 \\
2 \\
2 \\
\end{array}$ & $\begin{array}{l}\text { Porque elas são legal e eu fico } \\
\text { tranquila quando escuto. }\end{array}$ & $\begin{array}{c}\text { Bem estar } 5 \\
\text { Transcendência do } \\
\text { cotidiano } 4 \\
\end{array}$ \\
\hline Q10 & Nada bom, Sorry, Sem graça. & $\begin{array}{l}1 \\
1 \\
1\end{array}$ & $\begin{array}{l}\text { Por que me fazem me sentir bem, a } \\
\text { maioria me descreve. }\end{array}$ & $\begin{array}{c}\text { Bem estar } 6 \\
\text { Identificação pessoal } 1\end{array}$ \\
\hline Q11 & $\begin{array}{c}\text { Children. } \\
\text { ElasgostamAssim. } \\
\text { What do You Mean? }\end{array}$ & $\begin{array}{l}1 \\
1 \\
1\end{array}$ & $\begin{array}{l}\text { Porque elas são eletrizantes. são } \\
\text { muito doidas. }\end{array}$ & $\begin{array}{l}\text { Elemento musical - } \\
\text { expressão musical } 1 ; \\
\text { Entretenimento } 4 \\
\end{array}$ \\
\hline Q12 & $\begin{array}{l}\text { Metralhadora. } \\
\text { Bar das coleguinhas. }\end{array}$ & $\begin{array}{l}3 \\
1\end{array}$ & Porque são muito elegantes. & $\begin{array}{l}\text { Entretenimento } 5 \\
\text { Expressividade musical } 2\end{array}$ \\
\hline Q13 & $\begin{array}{c}\text { Metralhadora. } \\
\text { Hungria. } \\
\text { Tá tranquilo, tá favorável. }\end{array}$ & $\begin{array}{l}4 \\
3 \\
\end{array}$ & Por causa da letra e são massa. & $\begin{array}{l}\text { Elemento musical - letra 5; } \\
\text { Entretenimento } 6\end{array}$ \\
\hline Q14 & $\begin{array}{c}\text { Caia fogo. } \\
\text { Mina de virtude. } \\
\text { Som da liberdade. } \\
\end{array}$ & $\begin{array}{l}1 \\
1 \\
1\end{array}$ & $\begin{array}{l}\text { Porque traz paz e um sentimento de } \\
\text { amor. }\end{array}$ & $\begin{array}{c}\text { Bem estar } 7 \\
\text { Transcendência do } \\
\text { cotidiano } 5 \\
\end{array}$ \\
\hline Q15 & $\begin{array}{c}\text { Funks, bar das coleguinhas e } \\
\text { Rap. }\end{array}$ & 2 & $\begin{array}{c}\text { Porque anima expressa } \\
\text { sentimentos. }\end{array}$ & Entretenimento 7 \\
\hline Q16 & $\begin{array}{c}\text { Metralhadora. } \\
\text { Magic Hud. } \\
\text { Tá tranquilo ,tá favorável. } \\
\end{array}$ & $\begin{array}{l}5 \\
1 \\
4\end{array}$ & Por que são legais e divertidas. & Entretenimento 8 \\
\hline Q17 & $\begin{array}{c}\text { Realidade cruel. } \\
\text { Sonho } \\
\text { Te amo. }\end{array}$ & $\begin{array}{l}1 \\
1 \\
1\end{array}$ & $\begin{array}{l}\text { Porque é um Rap, transmite } \\
\text { adrenalina e porque são um } \\
\text { sertanejo universitário. }\end{array}$ & $\begin{array}{l}\text { Identificação pessoal } \\
\text { 2;Gosto }\end{array}$ \\
\hline Q18 & $\begin{array}{l}\text { Dracma perdida. } \\
\text { Ao único. } \\
\text { Aos olhos do pai. }\end{array}$ & $\begin{array}{l}1 \\
1 \\
1 \\
\end{array}$ & $\begin{array}{l}\text { Por que elas tocam o coração. Faz } \\
\text { refletir. }\end{array}$ & $\begin{array}{c}\text { Bem estar } 8 \\
\text { Transcendência do } \\
\text { cotidiano - } 6 \\
\end{array}$ \\
\hline
\end{tabular}




\begin{tabular}{|l|c|c|c|c|}
\hline Q19 & $\begin{array}{c}\text { Sertanejo, bar das coleguinhas e } \\
\text { Funks. }\end{array}$ & 3 & Porque é bom ouvir música & Bem estar 9 \\
\hline
\end{tabular}

\begin{tabular}{|c|c|c|}
\hline \multicolumn{2}{|c|}{ INCIDÊNCIA RESPOSTAS PARA TRÊS MÚSICAS QUE VOCÊ GOSTA. (N=19) } \\
\hline Metralhadora & 5 & $26,32 \%$ \\
\hline Tá tranquilo, tá favorável & 4 & $21,05 \%$ \\
\hline Bar das Coleguinhas & 3 & $15,79 \%$ \\
\hline Baile da Favela & 2 & $10,53 \%$ \\
\hline Não gosta de ouvir música & 1 & $5,26 \%$ \\
\hline Funks & 2 & $10,53 \%$ \\
\hline Rap e Sertanejo & 1 & $5,26 \%$ \\
\hline $\begin{array}{c}\text { Beautifull, When she's gone. Envolvidão.Bob voltou. Viva seu melhor. Mc Krum Vera Cruz. } \\
\text { Raridade. Sempre vida loka, depois da zero, Jesus chorou. O escudo. Advogado fiel. O maior } \\
\text { troféu. Eu te amo sexta-feira. Se cuida. Love Yourself. Nada bom, Sorry, Sem graça; Children. } \\
\begin{array}{c}\text { Elas gostam Assim. What do YouMean?Hungria. Caia fogo. Mina de virtude. Som da liberdade; } \\
\text { Magic Hud; Realidade cruel. Sonho; Te amo; Dracma perdida. Ao único. Aos olhos do pai. }\end{array}\end{array}$ & 1 & $5,26 \%$ \\
\hline
\end{tabular}

\section{INCIDÊNCIAS CATEGORIAS: EXPLIQUE PORQUE VOCÊ GOSTA DESSAS MÚSICAS (N=19)}

\begin{tabular}{|c|c|c|}
\hline Bem estar & 9 & $47,37 \%$ \\
\hline Entretenimento & 8 & $42,10 \%$ \\
\hline Transcendência do cotidiano & 6 & $31,58 \%$ \\
\hline Mensagem, Letra & 5 & $26,31 \%$ \\
\hline Expressividade & 2 & $10,53 \%$ \\
\hline $\begin{array}{c}\text { Memória; socialização; identificação pessoal; afetividade; visão positiva do } \\
\text { mundo }\end{array}$ & 1 & $5,26 \%$ \\
\hline
\end{tabular}




\begin{tabular}{|c|c|c|c|c|}
\hline \multicolumn{5}{|c|}{ ANALISE DAS QUESTÕES ABERTAS QUESTIONÁRIO (N=19) } \\
\hline & $\begin{array}{c}\text { O que é música para } \\
\text { você? }\end{array}$ & CATEGORIAS & $\begin{array}{c}\text { Para que serve a } \\
\text { música? }\end{array}$ & CATEGORIAS \\
\hline Q1 & Não respondeu & 1 & $\begin{array}{l}\text { É uma forma de ligar e } \\
\text { comunicar sentimentos. }\end{array}$ & $\begin{array}{l}\text { Expressividade 1; } \\
\text { Comunicação 1; }\end{array}$ \\
\hline Q2 & Não respondeu & 2 & $\begin{array}{l}\text { Serve para se expressar } \\
\text { atravez da música. }\end{array}$ & Expressividade 2 \\
\hline Q3 & $\begin{array}{l}\text { A música é uma coisa que } \\
\text { não sabemos mas que } \\
\text { gostamos, que é composta } \\
\text { por artista , mas que } \\
\text { expressa alguma coisa. }\end{array}$ & $\begin{array}{l}\text { Expressividade } 1 ; \\
\text { gosto/Identificaçã } \\
\text { o pessoal 1; visão } \\
\text { artística } 1\end{array}$ & $\begin{array}{l}\text { Para expressar } \\
\text { sentimentos, para nos } \\
\text { envolvermos. }\end{array}$ & Expressividade 3 \\
\hline Q4 & $\begin{array}{l}\text { A música é uma sequência } \\
\text { de notas acompanhada por } \\
\text { um ritmo. }\end{array}$ & Visão formal 1 & $\begin{array}{c}\text { Para acompanhar o } \\
\text { sentimento do ouvinte. }\end{array}$ & Expressividade 4 \\
\hline Q5 & $\begin{array}{l}\text { São cançãos tocadas e } \\
\text { cantadas pelos cantores } \\
\text { artistas. }\end{array}$ & visão artística 2 & $\begin{array}{c}\text { Para ser ouvida de } \\
\text { acordo com o estilo que } \\
\text { você gosta. }\end{array}$ & $\begin{array}{c}\text { Gosto/Identificação } \\
\text { pessoal 1; } \\
\text { Entretenimento 5; }\end{array}$ \\
\hline Q6 & $\begin{array}{l}\text { Tudo aquilo que se ouve } \\
\text { que é legal. }\end{array}$ & $\begin{array}{c}\text { Bem estar 1; } \\
\text { gosto/Identificaçã } \\
\text { o pessoal } 2\end{array}$ & $\begin{array}{l}\text { Uma forma de se } \\
\text { expressar para as } \\
\text { pessoas. }\end{array}$ & Expressividade 6 \\
\hline Q7 & $\begin{array}{l}\text { A música decifra a } \\
\text { realidade de muitos e } \\
\text { também ensina. }\end{array}$ & $\begin{array}{l}\text { Representação da } \\
\text { realidade 1; } \\
\text { comunicação } 1\end{array}$ & $\begin{array}{l}\text { A música serve para } \\
\text { aprender a relaxar. }\end{array}$ & Bem estar 1 \\
\hline Q8 & $\begin{array}{l}\text { A música também é uma } \\
\text { arte, que expressa } \\
\text { sentimentos de uma forma } \\
\text { diferente. }\end{array}$ & $\begin{array}{l}\text { visão artística 3; } \\
\text { expressividade } 2\end{array}$ & $\begin{array}{l}\text { Para relaxar, para } \\
\text { desestressar, etc. }\end{array}$ & Bem estar 2 \\
\hline Q9 & $\begin{array}{l}\text { Tudo aquilo que ouve que é } \\
\text { grave ou agudo. }\end{array}$ & Visão formal 2 & $\begin{array}{l}\text { Uma forma de se } \\
\text { expressar para as } \\
\text { pessoas. }\end{array}$ & Expressividade 7 \\
\hline Q10 & $\begin{array}{l}\text { É uma forma de } \\
\text { comunicação de } \\
\text { centimentos. }\end{array}$ & Expressividade 4 & $\begin{array}{l}\text { Para expressar } \\
\text { centimentos. }\end{array}$ & Expressividade 8 \\
\hline Q11 & $\begin{array}{l}\text { Música é o que você pensa } \\
\text { e que se expressar em } \\
\text { forma de música. }\end{array}$ & $\begin{array}{l}\text { Expressividade 4; } \\
\text { Comunicação } 2\end{array}$ & Para se expressar. & Expressividade 9 \\
\hline Q12 & $\begin{array}{l}\text { Música é uma forma de } \\
\text { espressa sentimento. }\end{array}$ & Expressividade 5 & Para uma diversão. & Entretenimento 6 \\
\hline Q13 & $\begin{array}{l}\text { São textos com ritmo e } \\
\text { coisas que rimam. }\end{array}$ & Visão Formal 3 & Para escutar. & Apreciar ouvindo 1 \\
\hline Q14 & é uma cultura. & Visão cultural 1 & $\begin{array}{l}\text { Para expressar um } \\
\text { sentimento. }\end{array}$ & Expressividade 9 \\
\hline Q15 & Música é arte. & $\begin{array}{l}\text { Visão artística da } \\
\text { música } 4\end{array}$ & $\begin{array}{l}\text { As vezes para alegrar } \\
\text { para emocionar, etc. }\end{array}$ & $\begin{array}{c}\text { Expressividade, } 10 \\
\text { entretenimento } 7\end{array}$ \\
\hline Q16 & Música é arte. & $\begin{array}{l}\text { Visão artística da } \\
\text { música } 5\end{array}$ & Música é arte. & $\begin{array}{l}\text { Visão artística da } \\
\text { música } 1\end{array}$ \\
\hline Q17 & $\begin{array}{l}\text { Construção harmoniosa e } \\
\text { espressiva de sons. }\end{array}$ & Visão formal 4 & $\begin{array}{l}\text { A música relaxa a } \\
\text { mente para alguma } \\
\text { influências. }\end{array}$ & $\begin{array}{l}\text { Bem estar } 3 \text {; } \\
\text { relaxamento } 1\end{array}$ \\
\hline Q18 & Música é uma cultura. & Visão cultural 2 & $\begin{array}{l}\text { Para expressar } \\
\text { sentimento. }\end{array}$ & Expressividade 11 \\
\hline Q19 & Um tipo de arte. & Visão artística 6 & Para relaxar. & Bem estar 4; \\
\hline
\end{tabular}




\begin{tabular}{|c|c|c|c|c|c|}
\hline & & & & \multicolumn{2}{|c|}{ relaxamento 2} \\
\hline \multicolumn{6}{|c|}{ INCIDÊNCIA DAS CATEGORIAS $(\mathbf{N}=19)$} \\
\hline $\begin{array}{c}\text { Categorias: } O \text { que é } \\
\text { música para você? }(n=17)\end{array}$ & $\begin{array}{c}\text { Qtde } \\
(\mathrm{n}=17)\end{array}$ & $\begin{array}{c}\% \\
(n=17)\end{array}$ & $\begin{array}{c}\text { Categorias: Para que serve a } \\
\text { música? }(\mathrm{N}=19)\end{array}$ & $\begin{array}{c}\text { Qtde } \\
(\mathbf{N}=19)\end{array}$ & $\begin{array}{c}\% \\
(\mathrm{~N}=19)\end{array}$ \\
\hline Visão Artística da Música & 6 & $35,29 \%$ & Expressividade & 11 & $57,89 \%$ \\
\hline Expressividade & 5 & $29,41 \%$ & Entretenimento & 7 & $36,84 \%$ \\
\hline Visão Formal & 4 & $23,52 \%$ & Bem estar & 4 & $21,05 \%$ \\
\hline $\begin{array}{l}\text { Visão Cultural e } \\
\text { Comunicação }\end{array}$ & 2 & $11,76 \%$ & Relaxamento & 2 & $10,53 \%$ \\
\hline $\begin{array}{c}\text { Representação da } \\
\text { Realidade; Bem estar; } \\
\text { Gosto e Identificação } \\
\text { pessoal }\end{array}$ & 1 & $5,88 \%$ & $\begin{array}{l}\text { Apreciar ouvindo; Comunicação; } \\
\text { Visão artística da música; } \\
\text { Gosto/Identificação pessoal; }\end{array}$ & 1 & $5,26 \%$ \\
\hline Não respondeu $(\mathrm{N}=19)$ & 2 & $10,53 \%$ & Não respondeu & 0 & $0 \%$ \\
\hline
\end{tabular}

\begin{tabular}{|c|c|c|}
\hline \multicolumn{3}{|c|}{ ANÁLISE DAS QUESTÕES ABERTAS QUESTIONÁRIO (N=19) } \\
\hline $\mathbf{Q}$ & Escreva o nome de três músicas que estão na moda. & INCIDÊNCIAS \\
\hline Q1 & Sorry, Tá tranquilo tá favorável. De longe & $1 ; 1 ; 1$ \\
\hline Q2 & Tá tranquilo,tá favorável. Metralhadora. Eu sosseguei. & $2 ; 1 ; 1$ \\
\hline Q3 & Metralhadora, Susseguei. & $2 ; 2$ \\
\hline Q4 & Tá tranquilo, tá favorável. Baile de favela. Metralhadora. & $3 ; 1 ; 3$ \\
\hline Q5 & Metralhadora. Meu violão e o nosso cachorro. Porque homem não chora. & $4 ; 1 ; 1$ \\
\hline Q6 & Baile de Favela; Metralhadora.Chefe é chefe, né pai? & $2 ; 5 ; 1$ \\
\hline Q7 & Baile de Favela. Tá tranquilo, tá favorável. Metralhadora. & $3 ; 4 ; 6$ \\
\hline Q8 & Metralhadora; Tá tranquilo tá favorável; Baile de favela & $7 ; 5 ; 4$ \\
\hline Q9 & Baile de Favela. Metralhadora.Tá tranquilo tá favorável. & $5 ; 8 ; 6$ \\
\hline Q10 & Nada bom, Sorry, Sem graça. & $1 ; 2 ; 1$ \\
\hline Q11 & Metralhadora. Baile de Favela.Tátranquilo,tá favorável. & $8 ; 6 ; 7$ \\
\hline Q12 & Metralhadora. Bar das coleguinhas. & $9 ; 1$ \\
\hline Q13 & Metralhadora. Hungria. Tá tranquilo, tá favorável. & $10 ; 1 ; 8$ \\
\hline Q14 & Baile de Favela; Metralhadora; Tá tranquilo tá favorável. & $7 ; 11 ; 9$ \\
\hline Q15 & Paredão; Metralhadora; Bar das coleguinhas.Funks & $1 ; 12 ; 2 ; 1$ \\
\hline Q16 & Metralhadora. Tá tranquilo, tá favorável; Baile da favela. & $13 ; 10 ; 8$ \\
\hline Q17 & Tá tranquilo, tá favorável; Metralhadora; Baile de favela. & $11 ; 14 ; 9$ \\
\hline Q18 & Metralhadora. Tá tranquilo, tá favorável; Baile de Favela. & $15 ; 12 ; 10$ \\
\hline Q19 & Paredão; Metralhadora. Bar das coleguinhas. Tranquilo tá Favorável. & $2 ; 16 ; 3 ; 13$ \\
\hline
\end{tabular}




\begin{tabular}{|l|l|l|}
\hline \multicolumn{2}{|c|}{ INCIDÊNCIA DAS MÚSICAS INDICADAS COMO 'DA MODA' (N=19) } \\
\hline Música & Qtde & $\%$ \\
\hline Metralhadora & 16 & $84,21 \%$ \\
\hline Tá tranquilo, tá favorável & 13 & $68,42 \%$ \\
\hline Baile de Favela & 10 & $52,73 \%$ \\
\hline Bar das Coleguinhas & 3 & $15,79 \%$ \\
\hline Paredão; Eu sosseguei e Sorry & 2 & $10,53 \%$ \\
\hline $\begin{array}{l}\text { De longe; Meu violão e o nosso cachorro; Porque homem não chora; Chefe é chefe, } \\
\text { né pai?; Nada bom; Sem graça; Hungria e Funks (estilo) }\end{array}$ & 1 & $5,26 \%$ \\
\hline
\end{tabular}




\section{APÊNDICE G: PLANOS DE AULA}

Identificação: Aula 01/02 - Aplicação do Questionário Sócio-Econômico

Nome: Centro de Ensino Fundamental 05 do Paranoá - DF

Série/Ano: $8^{\circ}$ "A"

Disciplina: Artes/Música

Duração: duas aulas de 45 minutos

Tema: Situação sócio econômica dos alunos

\section{Objetivos:}

Compreender e refletir sobre a realidade cotidiano do aluno par melhor elaboração de ação pedagógica que dialogue com a situação do aluno.

Promover o debate e a discussão acerca das interpretações das realidades.

Conteúdos: A importância da compreensão da realidade social como algo dialoga com nossa leitura de manifestação artística capaz de refletir e dialogar com a nossa realidade sócio econômica.

Procedimentos: Aplicação de questionário diagnóstico com questões abertas e fechadas e discussão prévia sobre as respostas.

\section{Materiais:}

Questionário diagnóstico.

Identificação: Aula 03/04 - Aplicação do Questionário 'Preferências Musicais e Mídia' Nome: Centro de Ensino Fundamental 05 do Paranoá - DF

Série/Ano:80 "A"

Disciplina: Artes/Música

Duração:duas aulas de 45 minutos 
Tema:Aplicação do Questionário: As preferências musicais adquiridas e impostas pela sugestão e repetição. O papel do questionamento a respeito daquilo que se ouve.

Objetivos:Diagnosticar, compreender e valorizar aquilo que o aluno ouve nos diferentes contextos bem como, questionar e refletir sobre o que se ouve e o porque se ouve.

Conteúdos:questionário com questões abertas e fechadas.

Procedimentos:Aplicação de questionário sobre preferências musicais com questões abertas e fechadas e discussão prévia sobre as respostas e análise dos dados.

Materiais:questionário, pandeiro, caixa de som e marcador para quadro banco.

Identificação: Aula 05/06 - Reflexão sobre os resultados

Nome: Centro de Ensino Fundamental 05 do Paranoá - DF

Série/Ano:80 "A"

Disciplina: Artes/Música

Duração:duas aulas de 45 minutos

Tema:Aplicação do questionário sobre vivência musical, experiência em educação musical e vivência musical.

Objetivos:Diagnosticar e refletir sobre o universo de referências e experiências do aluno.

Conteúdos:questionário com questões abertas e fechadas.

Procedimentos:discussão e reflexão prévia breve sobre algunsindicativos dosresultados, como as preferências de estilo e os elementos apontados como os mais importantes na escuta por parte dos alunos . 
Demonstração de exemplos de estilos e ritmos no pandeiro e cantada como: trecho de Rap, trechos de xote, trecho de funk carioca, todos executados com a voz, pandeiro e com a marcação de pulso coletiva por parte da turma.

Segundo momento: utilização de aparelho de rádio para demonstração da dinâmica comercial do veículo.

Observação do parâmetro sonoro intensidade mais efetivo na hora da propaganda.

Observação das músicas da moda e análiseda temática das composições que tocam na rádio.

Comparação entre as preferências do questionário e a programação do rádio ao vivo.

Materiais:pandeiro, caixa de som, rádio,questionário, marcador para quadro branco.

Identificação: Aula 07/08 - Composição Coletiva

Nome: Centro de Ensino Fundamental 05 do Paranoá - DF

Série/Ano:80 "A"

Disciplina: Artes/Música

Duração:duas aulas de 45 minutos

\section{Tema:Composição Coletiva}

Objetivos:Compôr coletivamente a partir de discussão reflexiva proveniente das temáticas assinaladas nos questionários sócio-econômico e de preferências e vivências musicais. Executar e arranjar a composição coletivamente pelo maior número possível de indivíduos dentro da sala de aula.

Conteúdos:células rítmicas, pequenos padrões melódicos, noções formais de pulso e andamento, composição e performance.

Procedimentos: exercício coletivo de aquecimento corporal com execução de células rítmicas com a voz e com o corpo, executando elementos rítmicos populares brasileiros como: a célula básica do samba, do baião e do maculelê (célula do funk carioca). 
Comparação e reflexão sobre as temáticas presentes na maioria das músicas tocadas pela grande mídia.

Apresentação das cinco temáticas: sexo; drogas; festa; consumo e violência.

Discussão sobre a insistência do mercado cultural em propagar e doutrinar essas preferências na sugestão do comportamento dos jovens.

Observação coletiva sobre a possibilidade reflexiva de se resumir as temáticas em uma grande temática. A violência.

O jovem como objeto e mecanismo da perpetuação da violência pela divulgação e escuta das composições tocadas na rádio.

Discussão coletiva e direcionamento na solução e transformação da violência pela educação, a possibilidade da arte como um mecanismo de libertação da alma e do espírito.

Sugestão de composição coletiva (letra), sobre uma base pré acordada coletivamente, executada em pandeiro e gravada nos celulares.

Os alunos ouvirão a base rítmica que escolheram e irão compor uma letra sobre a educação transformando o cenário de violência e executarão coletivamente com um professor, tocando a base rítmica ao vivo e regendo.

Materiais:pandeiro, caixa de som, celular, caderno, marcador para quadro branco.

Identificação: Aula 09-Intervenção para a apreciação e reflexão. Ampliação do repertório. Nome: Centro de Ensino Fundamental 05 do Paranoá - DF

Série/Ano:8 " $\mathrm{A}$ "

Disciplina: Artes/Música

Duração:uma aula de 45 minutos

Tema: as diversas possibilidades de músicas que trazem à reflexão nos diferentes estilos. Identificação de elementos estruturais nos estilos musicais como batida, letra e melodia. Possibilidade de músicas apresentarem temáticas de protesto. Introdução a novos estilos como ópera, audição de motetos (Beba Coca-Cola - de Gilberto Mendes), Tropicália, de CaetanoVeloso. 
Objetivos:Fornecer e refletir junto ao aluno a noção de diversidade de temas e estilos musicais.

Observação e análise musical a partir da batida, da letra e da melodia.

Análise da temática e da postura política e reflexiva contida em composições.

A arte musical como mecanismo de questionamento e transformação.

Apresentação da Ópera e sua importânciana construção do pensamento musical.

Conteúdos:Apresentação na íntegra de Tropicália de Caetano Veloso e Beba Coca-Cola de Gilberto Mendes.

Análise de elementos da batida, letra e melodia.

Procedimentos:exercício com apresentação da ideia de moteto, exercícios de execução rítmica e de análise de estrutura de composição: identificação de partes da música e de contrastes.

Materiais:rádio,marcador para quadro branco, data show.

Identificação: Aula 10 - Ópera dos três vinténs e as diferentes releituras (Goethe), Chico Buarque.

Nome: Centro de Ensino Fundamental 05 do Paranoá - DF

Série/Ano: $8^{\circ}$ "A"

Disciplina: Artes/Música

Duração: uma aula de 45 minutos

Tema:a música de protesto nos diferentes séculos e estilos. A ironia, o sarcasmo e a violência abordados sob uma reflexão crítica.

\section{Objetivos:}

Conteúdos:obras musicais. 
Procedimentos:A obra musical apreciada e analisada Ópera do Malandro de Chico Buarque de Holanda, especialmente, a canção $O$ Malandro e, por interrelação a canção MackieMesser (Makie Navalha) da Ópera dos três vinténs de Kurt Weill e Bertold Brecht em diferentes versões (original, jazz e samba)

Materiais:data show, computador, marcador para quadro branco, caixa de som, pandeiro. 